\title{
Pulmonary exacerbations in children with cystic fibrosis
}

Citation for published version (APA):

van Horck, M. W. P. (2017). Pulmonary exacerbations in children with cystic fibrosis: risk factors, early detection, and health-related quality of life. [Doctoral Thesis, Maastricht University]. Maastricht University. https://doi.org/10.26481/dis.20170922mvh

Document status and date:

Published: 01/01/2017

DOI:

10.26481/dis.20170922mvh

Document Version:

Publisher's PDF, also known as Version of record

\section{Please check the document version of this publication:}

- A submitted manuscript is the version of the article upon submission and before peer-review. There can be important differences between the submitted version and the official published version of record.

People interested in the research are advised to contact the author for the final version of the publication, or visit the DOI to the publisher's website.

- The final author version and the galley proof are versions of the publication after peer review.

- The final published version features the final layout of the paper including the volume, issue and page numbers.

Link to publication

\footnotetext{
General rights rights.

- You may freely distribute the URL identifying the publication in the public portal. please follow below link for the End User Agreement:

www.umlib.nl/taverne-license

Take down policy

If you believe that this document breaches copyright please contact us at:

repository@maastrichtuniversity.nl

providing details and we will investigate your claim.
}

Copyright and moral rights for the publications made accessible in the public portal are retained by the authors and/or other copyright owners and it is a condition of accessing publications that users recognise and abide by the legal requirements associated with these

- Users may download and print one copy of any publication from the public portal for the purpose of private study or research.

- You may not further distribute the material or use it for any profit-making activity or commercial gain

If the publication is distributed under the terms of Article $25 \mathrm{fa}$ of the Dutch Copyright Act, indicated by the "Taverne" license above, 


\section{Pulmonary exacerbations in children with cystic fibrosis}

Risk factors, early detection, and health-related quality of life 
(C) Marieke van Horck, Maastricht 2017

No part of this book may be reproduced or transmitted in any form or by any means, without prior permission in writing by the author, or when appropriate, by the publishers of the publications.

Cover design: Stipt Creatie en Vorm, Angelique Rongen-Creemers

Layout: $\quad$ Tiny Wouters

Production: Gildeprint

ISBN/EAN: $\quad 9789462337084$

The research presented in this thesis was conducted at the School for Public Health and Primary Care: CAPHRI, Department of Paediatrics, Maastricht University.

This PhD research was funded by grants from the Dutch Cystic Fibrosis Foundation and Chiesi Pharmaceuticals.

Financial support for printing of this thesis was kindly provided by: Stichting ter bevordering Kindergeneeskunde, Maastricht Instruments BV, CareFusion BV and Chiesi Pharmaceuticals BV. 


\title{
Pulmonary exacerbations in children
}

\section{with cystic fibrosis}

\author{
Risk factors, early detection, and health-related \\ quality of life
}

\begin{abstract}
PROEFSCHRIFT
ter verkrijging van de graad van doctor aan de Universiteit Maastricht, op gezag van de Rector Magnificus, Prof. dr. Rianne M. Letschert, volgens het besluit van het College van Decanen, in het openbaar te verdedigen op vrijdag 22 september 2017 om 14.00 uur
\end{abstract} door Marieke Wilhelmina Petronella van Horck 


\section{Promotores}

Prof. dr. E. Dompeling

Prof. dr. G.J Wesseling

Co-promotor

Dr. B. Winkens

\section{Beoordelingscommissie}

Prof. dr. L.J.I. Zimmermann (voorzitter)

Prof. dr. C. de Boeck (Universitair Ziekenhuis Leuven)

Dr. H.G.M. Heijerman (Universitair Medisch Centrum Utrecht)

Prof. dr. B.W.W. Kramer

Prof. dr. P.H.M. Savelkoul 


\section{Contents}

Chapter 1 General introduction

Chapter 2 Factors associated with changes in health-related quality of life

in children with cystic fibrosis during 1-year follow-up

Eur J Pediatr (2017) 176:1047-1054

Chapter 3 Risk factors for future exacerbations in children with cystic fibrosis

submitted for publication

Chapter 4 Biomarkers in exhaled breath condensate

are not predictive for pulmonary exacerbations in children with

cystic fibrosis: results of a 1-year observational study

PLoS One 2016; 11(4): e0152156

Chapter 5 Exhaled volatile organic compounds early detect pulmonary

exacerbations in children with cystic fibrosis: results of a 1-year

observational study

submitted for publication

Chapter 6 Early detection of pulmonary exacerbations in children with cystic fibrosis by electronic home monitoring of symptoms and lung function

Accepted for publication, Scientific Reports 2017

Chapter 7 General discussion

Summary

Samenvatting

Valorisation

Dankwoord

Curriculum vitae

List of publications 



\section{Chapter 1}

General introduction 


\section{General introduction}

\section{Introduction}

Cystic fibrosis (CF) is an autosomal recessive life-shortening disease that affects multiple organs, such as the lungs, pancreas and intestines. ${ }^{1} \mathrm{CF}$ is prevalent in all continents and population groups. The overall birth prevalence of CF in the Netherlands between 1974 to 1994 was 1 in 4,750 live births. ${ }^{2}$ In 2014, 1,530 people with CF or CF related disorders lived in the Netherlands, almost half of them were children. ${ }^{3}$ Only 59 patients were older than 50 years of age, which comprises $3.86 \%$ of all the Dutch patients. ${ }^{3}$ Children with CF born in the UK today are expected to have a median survival of 50 years while 10-20 years ago this was only 30 years. ${ }^{4}$ Fortunately, survival and quality of life have progressively improved over the last decades. Explanations for this improvement are new-born screening programmes, ${ }^{5}$ optimisation of therapies due to better insights into the natural course of the disease, and specialised dedicated multidisciplinary CF teams. ${ }^{6}$ The prognosis of patients with CF is partly determined by the mutation class (genotype) but is also influenced by many other factors such as frequency and severity of pulmonary exacerbations (PEx), nutritional status, and adherence to the intensive treatment regimen. ${ }^{7}$ There is still an urgent need for strategies to further improve morbidity, mortality and health-related quality of life (HRQoL) in patients with CF.

$\mathrm{CF}$ is caused by a mutation in the cystic fibrosis transmembrane conductance regulator (CFTR) gene, which was discovered in 1989. ${ }^{8}$ Since then, more than 1500-2000 different mutations are identified and divided into 5 (or 6) classes, all of them leading to a defective or absent CFTR protein. ${ }^{7,9}$ CFTR is expressed in the apical membrane of epithelial cells. A defective protein causes problems in organs with a secretory function such as the lungs, pancreas and liver. ${ }^{10}$ Patients with class I, II and III mutations have no residual CFTR function and on average a severe phenotype and pancreatic insufficiency. Contrastingly, patients with class IV, V and VI mutations have on average a more mild lung phenotype and pancreatic sufficiency. ${ }^{7}$ The exact pathophysiology of CF (lung) disease is still unclear. One of the hypotheses how CFTR dysfunction leads to the disease CF is an imbalance between pro-inflammatory and anti-inflammatory mediators leading to a chronic inflammation of for instance the airways. ${ }^{1}$ This chronic inflammation is dominated by neutrophils. ${ }^{11}$ Another hypothesis is that impaired mucociliary clearance caused by abnormal hydration of airway surface liquid is the major underlying defect in CF. ${ }^{12}$ Finally, reduced concentrations of bicarbonate (also conducted by CFTR) in airway surface liquid and mucus leading to an altered $\mathrm{pH}$ and abnormal airway mucus function may explain CF lung disease. ${ }^{7}$ 


\section{Cystic fibrosis lung disease}

The hallmark of cystic fibrosis lung disease is chronic airway infection and inflammation, progressing to irreversible airway obstruction, bronchiectasis and air trapping, and eventually leading to respiratory failure. ${ }^{1,13}$ At least $80 \%$ of CF-related deaths are caused by pulmonary insufficiency. ${ }^{1} \mathrm{CF}$ lung disease is characterised by PEx, i.e. acute changes in respiratory signs and symptoms from the patient's baseline, necessitating additional treatment. ${ }^{13}$ There is no universally accepted definition of PEx, patients present with a variety of symptoms such as increased cough, increased sputum production, increased dyspnoea, decreased energy level and appetite, weight loss and deterioration of lung function parameters. ${ }^{14}$ The consensus is that the clinical need for additional treatment as indicated by a recent change in clinical parameters, provides the best definition of an exacerbation. ${ }^{15}$ Treatment with mucolytic agents, prophylactic antibiotics, antiinflammatory drugs but also non-pharmacological treatments such as airway clearance techniques and optimising nutritional status do positively influence CF lung disease by preventing PEx and retaining a better lung function. ${ }^{7}$ Nevertheless, PEx still occur and profoundly influence CF lung disease progression and health-related quality of life (HRQoL) of patients with CF. ${ }^{16}$ Little is known about the pathophysiology of these exacerbations. However, the acquisition of new bacteria or a change in the bacterial density of colonizing flora, but also viral infections play a role in triggering PEx. ${ }^{14,17}$ Currently PEx are diagnosed and treated with antibiotics when apparent, there is no (gold standard) test to diagnose PEx. Severe PEx are often treated with intravenous antibiotics and hospitalisation, whereas less severe exacerbations are commonly treated with oral antibiotics. ${ }^{14,17}$ The duration of antibiotic treatment is another subject of discussion as there is lack of evidence to recommend an optimal duration. ${ }^{18}$ Moreover, it often takes some time before patients seek medical care. This patient delay may introduce subsequent delay in starting antibiotic treatment, potentially resulting in a more severe course of the PEx and a higher risk on permanent lung function loss. Therefore, early detection of exacerbations is important and in combination with early treatment may prevent part of the exacerbations. Furthermore, preventing a more severe course of PEx with hospital admissions and intravenous antibiotics, may reduce the risk of permanent lung function loss and slow down lung disease progression. Exacerbation rates increase with age and more severe lung disease: data from the Epidemiologic Study of CF showed an increasing PEx rate from $23 \%$ of children under 6 years of age to $63 \%$ in those over 18 years. ${ }^{19}$ Moreover, one quarter to one third of patients with CF do not recover to their baseline forced expiratory volume in 1 second $\left(\mathrm{FEV}_{1}\right)$ after a PEx. ${ }^{20,21}$ Furthermore, PEx also have an important negative effect on HRQoL. ${ }^{16}$ 


\section{Health-related quality of life}

With an increasing survival and aging CF population, HRQoL becomes more and more important for patients as well as their treating physicians. Therefore, HRQoL is increasingly used as a patient-reported outcome (PRO) measure for clinical trials. The cystic fibrosis questionnaire-revised (CFQ-R) is a widely used, validated, disease-specific instrument to measure HRQoL in CF. ${ }^{22}$ Moreover, the CFQ-R meets the criteria for PROs in clinical trials by the U.S. Food and Drug Administration (FDA). ${ }^{23} \mathrm{~A}$ trial assessing the effect of inhaled aztreonam lysine for chronic airway infection with Pseudomonas aeruginosa showed improved mean CFQ-R respiratory domain scores of 5.0. ${ }^{24}$ Another trial showed an improvement of 8.6 points on the respiratory symptom domain of the CFQ-R in patients treated with a CFTR potentiator (ivacaftor) compared to patients in the placebo group. ${ }^{25}$ Research has identified several factors influencing HRQoL such as age, gender, body mass index (BMI), PEx and $\mathrm{FEV}_{1} \cdot{ }^{26-28}$ However, most research was performed in adolescents and adults in clinical trials. In clinical practice, it is very important for paediatricians to know which factors influence HRQOL of children with CF (and their parents). Especially during adolescence, because in this challenging period limitations and demands of having CF typically increase. ${ }^{29}$ For instance, the influence of the number of chronic and intensive therapies is largely unknown. In adults, Sawicki et al. found that using two or more nebulised medications and performing airway clearance techniques for more than 30 minutes were significantly associated with increased treatment burden score (based on the CFQ-R). ${ }^{30}$ An intensification of treatment in case of a PEx might seem a logical step forward looking at medical outcomes, but the impact on HRQoL should not be overlooked. In conclusion, improving HRQoL justifiably is an important goal in the management of CF. ${ }^{19}$

\section{Progression of lung disease}

A way to monitor progression of lung disease is by imaging techniques, such as chest computed tomography (CT). Structural lung changes such as bronchiectasis and fibrosis are identified and monitored. ${ }^{31}$ Moreover, lung disease progression is often objectively assessed by lung function, more specifically by $\mathrm{FEV}_{1}$ as percentage of predicted value (FEV ${ }_{1} \%$ pred). ${ }^{32}$ However, especially in young children standard lung function is not yet measurable and other measures of lung disease progression have to be used, such as frequency of PEx. Byrnes et al. demonstrated that there are associations between frequent PEx and decreased $\mathrm{FEV}_{1}$ and the presence of bronchiectasis on chest $\mathrm{CT}$ at age $5^{33}$

In adults and children, known risk factors for lung function decline are chronic infection with Pseudomonas aeruginosa, low BMI and female gender. ${ }^{34}$ Risk factors for PEx are 
less extensively studied, probably also due to the lack of a standardised definition of PEx and the variations in treatment. For physicians it would be very useful to recognise patients at risk for future PEx. Identification of high risk patients allows physicians to intensify monitoring or to adjust treatment in order to slow down lung disease progression.

Currently, there is no test to predict or early detect PEx or assess their severity. Early detection of PEx will lead to earlier treatment, which may positively influence the course of PEx and improve long term prognosis. Davies et al described requirements for monitoring tools of respiratory disease (severity) in CF. Measurements should be sensitive, allow detection of short-term and long-term change, repeatable and reproducible, non-invasive and well-tolerated, applicable across age groups and to patients of different illness severity, and complementary in the information they provide to allow individually tailored management and provide long-term prognostic information to patients and professionals. ${ }^{32}$

\section{Early detection of pulmonary exacerbations}

There are some promising (biochemical) techniques to early detect PEx.

\section{Inflammatory markers in exhaled breath condensate (EBC)}

Chronic inflammation of the airways is a major characteristic of CF. The inflammatory response is excessive and dysregulated, and plays an important role in pulmonary exacerbations. ${ }^{35}$ Currently, we treat infections and try to regulate inflammation, but this is not based on objective measures of this airway inflammation. Only non specific systemic markers such as c reactive protein and erythrocyte sedimentation rate are sometimes used. Inflammatory markers can be measured in bronchoalveolar lavage fluid or bronchial biopsies, but bronchoscopy is an invasive technique and requires general anaesthesia. Therefore, it is important to develop a non-invasive method to measure inflammatory (airway) markers, especially for children. EBC consists for $99.9 \%$ of condensed vapour with highly diluted soluble volatile compounds, the remaining liquid $(0.1 \%)$ consists of entrapped non-volatile compounds and airway lining fluid droplets. ${ }^{36}$ These droplets are detached due to the turbulent flow of the exhaled air through the airways. EBC is collected via a system of exhaled air cooling, it is a simple technique requiring only quiet breathing of the subject. ${ }^{36}$ Collection of EBC is completely noninvasive, safe and fast, not bearing any health risks, and is also feasible in young children. ${ }^{37,38}$ This offers a unique opportunity to investigate inflammatory markers in this medium and to assess the potential of this method to early detect exacerbations in CF. 


\section{Volatile organic compounds (VOCS)}

VOCs are a diverse group of carbon-based chemicals that are volatile at room temperature. The source of exhaled VOCs can be exogenous or endogenous. Exogenous VOCs can be taken up as pollutants from the environment via the skin or by inhalation or ingestion. Endogenous VOCs are formed in the body during several (patho)physiological processes. ${ }^{39}$ Specific VOCs are formed in cell membranes during inflammation/oxidative stress, which may not only occur in the airways but also in other parts of the body. ${ }^{40}$ VOCs can be measured by various techniques; the gold standard to identify individual VOCs is gas chromatography mass spectrometry (GC-MS), where patterns of VOCs can be recognised by electronic noses. ${ }^{39,41}$ VOCs in exhaled breath had additional value in diagnosis and monitoring of various chronic airway diseases. ${ }^{39,41}$ Metabolomic profiling of exhaled VOCs was able to discriminate between children with CF and healthy controls, and was able to demonstrate colonisation with Pseudomonas aeruginosa in the lower airways. ${ }^{42}$ The diagnostic potential of exhaled VOCs to early detect PEx in children with CF is not studied yet.

\section{Home monitoring}

Another way to early detect pulmonary exacerbations might be home monitoring of lung function and symptoms. Early detection of changes in lung function and/or respiratory symptoms may give physicians more and better information to decide when to start therapy. Moreover, it could empower children and their families to monitor their disease (severity). In children with asthma, home monitoring was more effective in detecting a deterioration of asthma control than retrospective questionnaires. ${ }^{43}$ The potential benefit of E-health in the field of CF management and treatment is largely unknown.

When we are able to prevent PEx by early detection and early antibiotic treatment, we may be able to slow down lung disease progression and improve HRQoL. 


\section{Objectives of this thesis}

The general purpose of the studies in this thesis is to explore strategies to improve recognition of PEx, to assess factors related to quality of life in children with $\mathrm{CF}$, and to characterise patients with a high exacerbation risk.

The main objectives of this thesis are:

- To explore factors that influence change in HRQoL in children with $\mathrm{CF}$, and to evaluate the influence of (the number of) medications on HRQoL;

- To identify risk factors for PEx in children with CF;

- To study the potential of various methods to detect pulmonary CF exacerbations at an early stage like inflammatory markers in exhaled breath condensate (EBC), profiles of exhaled volatile organic compounds (VOCs), and home monitoring of symptoms and lung function.

\section{Outline of this thesis}

In chapter 2, HRQoL is studied in 49 children with CF during 1 year. We assess the relationship of various risk factors such as PEx, lung function decline and number of medications with changes of CFQ-R scores.

We make use of the national CF patient registry, a unique database, in chapter 3, to study 545 Dutch children with CF during 6 years to identify risk factors for future PEx.

Exhaled breath is an interesting medium to non-invasively evaluate airway inflammation in patients with lung diseases, we assess the potential of inflammatory markers in EBC (chapter 4) and of exhaled VOCs (chapter 5) to early detect PEx in 49 children with CF during 1 year.

Moreover, in chapter 6 , we assess the potential of home monitoring of lung function and respiratory symptoms in children with $\mathrm{CF}$, as a tool to detect PEx at an early stage.

Finally, in chapter 7 a general discussion of the findings in this thesis is given and recommendations for future research are made. 


\section{References}

1. O'Sullivan BP, Freedman SD. Cystic fibrosis. Lancet. 2009;373(9678):1891-904.

2. Slieker MG, Uiterwaal CS, Sinaasappel M, Heijerman HG, van der Laag J, van der Ent CK. Birth prevalence and survival in cystic fibrosis: a national cohort study in the Netherlands. Chest. 2005;128(4):2309-15.

3. Foundation DCF. Dutch Cystic Fibrosis Registry, Report 2014. 2014.

4. Dodge JA, Lewis PA, Stanton M, Wilsher J. Cystic fibrosis mortality and survival in the UK: 1947-2003. Eur Respir J. 2007;29(3):522-6.

5. Dijk FN, McKay K, Barzi F, Gaskin KJ, Fitzgerald DA. Improved survival in cystic fibrosis patients diagnosed by newborn screening compared to a historical cohort from the same centre. Arch Dis Child. 2011;96(12):1118-23.

6. Cohen-Cymberknoh M, Shoseyov D, Kerem E. Managing cystic fibrosis: strategies that increase life expectancy and improve quality of life. Am J Respir Crit Care Med. 2011;183(11):1463-71.

7. Elborn JS. Cystic fibrosis. Lancet. 2016.

8. Bosch B, De Boeck K. Searching for a cure for cystic fibrosis. A 25-year quest in a nutshell. Eur J Pediatr. 2016;175(1):1-8.

9. Fanen P, Wohlhuter-Haddad A, Hinzpeter A. Genetics of cystic fibrosis: CFTR mutation classifications toward genotype-based CF therapies. Int J Biochem Cell Biol. 2014;52:94-102.

10. Rowe SM, Miller S, Sorscher EJ. Cystic fibrosis. N Engl J Med. 2005;352(19):1992-2001.

11. Cantin AM, Hartl D, Konstan MW, Chmiel JF. Inflammation in cystic fibrosis lung disease: Pathogenesis and therapy. J Cyst Fibros. 2015;14(4):419-30.

12. Stoltz DA, Meyerholz DK, Welsh MJ. Origins of cystic fibrosis lung disease. N Engl J Med. 2015;372(16): 1574-5.

13. Ferkol T, Rosenfeld M, Milla CE. Cystic fibrosis pulmonary exacerbations. J Pediatr. 2006;148(2):259-64.

14. Goss CH, Burns JL. Exacerbations in cystic fibrosis. 1: Epidemiology and pathogenesis. Thorax. 2007;62(4): 360-7.

15. Bilton D, Canny G, Conway S, Dumcius S, Hjelte L, Proesmans M, et al. Pulmonary exacerbation: towards a definition for use in clinical trials. Report from the EuroCareCF Working Group on outcome parameters in clinical trials. J Cyst Fibros. 2011;10 Suppl 2:S79-81.

16. Britto MT, Kotagal UR, Hornung RW, Atherton HD, Tsevat J, Wilmott RW. Impact of recent pulmonary exacerbations on quality of life in patients with cystic fibrosis. Chest. 2002;121(1):64-72.

17. Waters V, Ratjen F. Pulmonary Exacerbations in Children with Cystic Fibrosis. Ann Am Thorac Soc. 2015;12 Suppl 2:S200-6.

18. Flume PA, Mogayzel PJ, Jr., Robinson KA, Goss CH, Rosenblatt RL, Kuhn RJ, et al. Cystic fibrosis pulmonary guidelines: treatment of pulmonary exacerbations. Am J Respir Crit Care Med. 2009;180(9):802-8.

19. Rabin HR, Butler SM, Wohl ME, Geller DE, Colin AA, Schidlow DV, et al. Pulmonary exacerbations in cystic fibrosis. Pediatr Pulmonol. 2004;37(5):400-6.

20. Sanders DB, Bittner RC, Rosenfeld M, Hoffman LR, Redding GJ, Goss CH. Failure to recover to baseline pulmonary function after cystic fibrosis pulmonary exacerbation. Am J Respir Crit Care Med. 2010;182(5):627-32.

21. Waters V, Atenafu EG, Salazar JG, Lu A, Yau Y, Matukas L, et al. Chronic Stenotrophomonas maltophilia infection and exacerbation outcomes in cystic fibrosis. J Cyst Fibros. 2012;11(1):8-13.

22. Quittner AL, Buu A, Messer MA, Modi AC, Watrous M. Development and validation of The Cystic Fibrosis Questionnaire in the United States: a health-related quality-of-life measure for cystic fibrosis. Chest. 2005;128(4):2347-54.

23. Administration UFaD. Guidance for industry patient-reported outcome measures: use in medical product development to support labeling claims.: Center for Biologics Evaluation and Research, US Dept of Health and Human Services; 2009.

24. McCoy KS, Quittner AL, Oermann CM, Gibson RL, Retsch-Bogart GZ, Montgomery AB. Inhaled aztreonam lysine for chronic airway Pseudomonas aeruginosa in cystic fibrosis. Am J Respir Crit Care Med. 2008;178(9):921-8.

25. Ramsey BW, Davies J, McElvaney NG, Tullis E, Bell SC, Dřevínek P, et al. A CFTR potentiator in patients with cystic fibrosis and the G551D mutation. N Engl J Med. 2011;365(18):1663-72. 
26. Hegarty M, Macdonald J, Watter P, Wilson C. Quality of life in young people with cystic fibrosis: effects of hospitalization, age and gender, and differences in parent/child perceptions. Child Care Health Dev. 2009;35(4):462-8.

27. Quittner AL, Sawicki GS, McMullen A, Rasouliyan L, Pasta DJ, Yegin A, et al. Erratum to: Psychometric evaluation of the Cystic Fibrosis Questionnaire-Revised in a national, US sample. Qual Life Res. 2012;21(7):1279-90.

28. Casier A, Goubert L, Theunis M, Huse D, De Baets F, Matthys D, et al. Acceptance and well-being in adolescents and young adults with cystic fibrosis: a prospective study. J Pediatr Psychol. 2011;36(4): 476-87.

29. Ernst MM, Johnson MC, Stark LJ. Developmental and psychosocial issues in cystic fibrosis. Child Adolesc Psychiatr Clin N Am. 2010;19(2):263-83, viii.

30. Sawicki GS, Sellers DE, Robinson WM. High treatment burden in adults with cystic fibrosis: challenges to disease self-management. J Cyst Fibros. 2009;8(2):91-6.

31. Tiddens HA, Rosenow T. What did we learn from two decades of chest computed tomography in cystic fibrosis? Pediatr Radiol. 2014;44(12):1490-5.

32. Davies JC, Alton EW. Monitoring respiratory disease severity in cystic fibrosis. Respir Care. 2009;54(5): 606-17.

33. Byrnes CA, Vidmar S, Cheney JL, Carlin JB, Armstrong DS, Cooper PJ, et al. Prospective evaluation of respiratory exacerbations in children with cystic fibrosis from newborn screening to 5 years of age. Thorax. 2013;68(7):643-51

34. Cogen J, Emerson J, Sanders DB, Ren C, Schechter MS, Gibson RL, et al. Risk factors for lung function decline in a large cohort of young cystic fibrosis patients. Pediatr Pulmonol. 2015.

35. Chmiel JF, Berger M, Konstan MW. The role of inflammation in the pathophysiology of CF lung disease. Clin Rev Allergy Immunol. 2002;23(1):5-27.

36. Konstantinidi EM, Lappas AS, Tzortzi AS, Behrakis PK. Exhaled Breath Condensate: Technical and Diagnostic Aspects. ScientificWorldJournal. 2015;2015:435160.

37. Bodini A, D'Orazio C, Peroni D, Corradi M, Folesani G, Baraldi E, et al. Biomarkers of neutrophilic inflammation in exhaled air of cystic fibrosis children with bacterial airway infections. Pediatr Pulmonol. 2005;40(6):494-9.

38. van Mastrigt E, de Jongste JC, Pijnenburg MW. The analysis of volatile organic compounds in exhaled breath and biomarkers in exhaled breath condensate in children - clinical tools or scientific toys? Clin Exp Allergy. 2015;45(7):1170-88.

39. van de Kant KD, van der Sande LJ, Jöbsis Q, van Schayck OC, Dompeling E. Clinical use of exhaled volatile organic compounds in pulmonary diseases: a systematic review. Respir Res. 2012;13:117.

40. Miekisch W, Schubert JK, Noeldge-Schomburg GF. Diagnostic potential of breath analysis--focus on volatile organic compounds. Clin Chim Acta. 2004;347(1-2):25-39.

41. Fens N, van der Schee MP, Brinkman P, Sterk PJ. Exhaled breath analysis by electronic nose in airways disease. Established issues and key questions. Clin Exp Allergy. 2013;43(7):705-15.

42. Robroeks CM, van Berkel JJ, Dallinga JW, Jöbsis Q, Zimmermann LJ, Hendriks HJ, et al. Metabolomics of volatile organic compounds in cystic fibrosis patients and controls. Pediatr Res. 2010;68(1):75-80.

43. van Vliet D, van Horck M, van de Kant K, Vaassen S, Gulikers S, Winkens B, et al. Electronic monitoring of symptoms and lung function to assess asthma control in children. Ann Allergy Asthma Immunol. 2014;113(3):257-62 e1. 




\section{Chapter}

Factors associated with changes in Health-Related
Quality of Life in children with cystic fibrosis during

1-year follow-up

Marieke van Horck, Bjorn Winkens, Geertjan Wesseling, Karin de Winter-de Groot, Ilja de Vreede, Quirijn Jöbsis, Edward Dompeling

Eur J Pediatr (2017) 176:1047-1054 


\section{Abstract}

\section{Background}

There are limited data on health-related quality of life (HRQoL) changes over time in children with cystic fibrosis (CF). We investigated associations between clinical and treatment variables with changes in $\mathrm{HRQ}$ oL during 1 year.

\section{Methods}

Forty-nine children with CF aged 6-18 years were followed in this multicentre, observational cohort study during 1 year. HRQoL was measured by the validated disease specific cystic fibrosis questionnaire-revised (CFQ-R).

\section{Results}

The CFQ-R total score as well as most domain scores improved significantly (8.0 points and [3.3-31.7] points respectively) during the 1-year follow-up. Age at baseline demonstrated a strong longitudinal association with the change of CFQ-R total score (2.853 points decrease of CFQ-R total score per year increase in age) and several domain scores. Below 12 years of age, CFQ-R total score improved in most children, whereas a deterioration was observed in most children above 12 years. The number of PEx was associated with an increase of treatment burden score (4.466 points decrease per extra PEx).

\section{Conclusion}

In the group as a whole, HRQoL improved significantly over time. However, changes over time were significantly influenced by age: below 12 years of age, HRQoL improved in most patients whereas a deterioration was observed in most children above 12 years. Strategies how to preserve or ideally to improve HRQoL in adolescence should be developed. 


\section{Introduction}

Survival in cystic fibrosis (CF) has improved drastically over the past decades, but is also accompanied by more CF-related co-morbidities and a greater treatment burden, which may impact quality of life. ${ }^{1}$ Quality of life in a chronic disease like CF is not only of major importance to patients but also to the treating physicians. Fortunately, in the management of $\mathrm{CF}$, there is an increasing focus on survival in combination with a good health-related quality of life (HRQOL). ${ }^{2}$ Moreover, HRQoL is increasingly used as a patient-related outcome measure for clinical trials in patients with $\mathrm{CF}^{3}$ Clinicians should be able to assess both the medical benefit and the contribution to quality of life of (new) treatments for each individual patient. ${ }^{2}$ Hence, it is important to identify factors associated with HRQoL, so clinicians can focus on prioritising and optimising management of factors that impact it at the most. ${ }^{4}$ The cystic fibrosis questionnairerevised $(C F Q-R)$ is a disease specific, validated HRQoL measure. ${ }^{5}$

Most research on quality of life in CF is performed in adults and has a cross-sectional study design, whereas the majority of longitudinal studies on HRQoL was conducted in clinical trials of CF therapies. Longitudinal data on $\mathrm{HRQOL}$ in non-intervention studies with children are currently lacking. Several cross-sectional studies showed that age, gender, body mass index (BMI), pulmonary exacerbations (PEX) and forced expiratory volume in $1 \mathrm{~s}\left(\mathrm{FEV}_{1}\right)$ appear to impact HRQoL as measured by the CFQ-R. ${ }^{6-9}$

Sawicki et al. demonstrated significant associations between respiratory symptoms and CFQ-R respiratory symptom scores, and between weight and scores on CFQ-R nutritional health domains in children and adults during 9-15 months of follow-up. ${ }^{10}$

In this prospective observational study during 1 year, we investigated associations between clinical and treatment variables with changes in CFQ-R scores in children with CF. We assumed that (1) pulmonary exacerbations and lung function decline are related to worsening of CFQ-R respiratory health domains; (2) the number of medications/inhalation therapies are associated with higher CFQ-R treatment burden scores. 


\section{Methods}

\section{Study design and patients}

Children with CF aged 5 to 19 years were included in this 1-year, multicentre, observational cohort study (clinicaltrial.gov NCT01241890). Children were recruited from three CF centres in the Netherlands (Maastricht, Utrecht and Amsterdam).

CF was defined as the presence of characteristic clinical features (persistent pulmonary symptoms, meconium ileus, failure to thrive, steatorrhea) in combination with an abnormal sweat test (chloride $>60 \mathrm{~mL}$ ) and/or two CF mutations. ${ }^{11}$ Exclusion criteria were (1) severe cardiac abnormalities; (2) mental disability; (3) no technically adequate performance of measurements; (4) on waiting list for lung transplantation; (5) children colonised with Burkholderia cepacia or Methicillin-rResistant Staphylococcus aureus (MRSA); (6) participation in an intervention trial.

Children with Burkholderia cepacia or MRSA were excluded as part of the study (not reported here) included breath measurements (exhaled volatile organic compounds and cytokines in exhaled breath condensate) which has a risk of cross-infection of other patients by the breath sampling equipment. Ethical approval was obtained from the Medical Ethical Committee of the Maastricht University Medical Centre. Informed consent was signed by all parents, and by children aged 12 years and over.

\section{Study parameters}

For the period of 1 year, all children attended regular clinical visits every 2 months. Demographic information and clinical characteristics (pancreatic insufficiency [use of pancreatic enzymes], BMI z scores and colonisation with Pseudomonas aeruginosa) were collected at inclusion. During each clinical visit, changes in treatment/medications were reported (total number of medications, number of inhalation therapies [such as DNA-se, hypertonic saline or antibiotic] and use of insulin). Besides, dynamic lung function parameters (Masterscreen Pneumo, Carefusion, Houten, The Netherlands) were assessed according to international standards. ${ }^{12}$ Recorded parameters were: $\mathrm{FEV}_{1}$, forced vital capacity (FVC), and maximum expiratory flow at $50 \%$ of FVC $\left(M^{2} F_{50}\right)$, all expressed as absolute rate and as percentage of the predicted normal value. Children and their parents were asked to fill in the CFQ-R questionnaire three times during the study; at inclusion, after 6 months, and after 1 year of follow-up. We defined change in CFQ-R scores during 1 year as main outcome measure (excluding CFQ-R scores filled in after 6 months). We used the translated and validated Dutch CFQ-R questionnaires appropriate for the different age groups ${ }^{9}$ : 6-3 years (child interview), 13-14 years of age (child self-report), and $\geq 14$ years (adolescents). Furthermore, parents of children aged 
6-13 years reported on a special parent version. The CFQ-R consists of 35-50 items divided into 7-9 domains (depending on age group): physical functioning, energy and well-being, emotional state, social limitations, role limitations, body image, eating disturbances, treatment burden, and embarrassment. Moreover, overall health perception and three symptom scales are included: respiratory, digestive and weight. Items require either a frequency response on a 4-point scale ('all the time' to 'never'), a difficulty rating on a 4-point scale ('a lot of difficulty' to 'no difficulty'), a true-false rating on a 4-point scale, or the selection of a statement that describes the patient (on a 3- or 4-point scale). The scores range from 0 to 100 with higher scores corresponding to higher quality of life. Only for the respiratory symptom domain a minimal clinically important difference (MCID), the smallest clinically relevant change a patient can detect, of 4.0 points (in stable patients) is determined. ${ }^{13}$ For the analysis of the separate domains, only those completed by all age groups were included (excluding energy and well-being, role limitations, embarrassment, and the weight symptom scale). The main outcome was change in CFQ-R total and domain scores in 1 year.

PEx were defined by courses of therapeutic antibiotics (intravenous and oral) prescribed by the responsible paediatric pulmonologists, considering the clinical symptoms as an expression of a PEx. PEx were treated according to the Dutch Central Guidance Committee (CBO) guideline, ${ }^{14}$ which resembles European ${ }^{11}$ and American CF guidelines. $^{15}$

\section{Statistical analysis}

Descriptive statistics of the baseline characteristics were expressed as mean (standard deviation [SD]) or as median (interquartile range (IQR), i.e. $25^{\text {th }}-75^{\text {th }}$ percentile) for numerical variables, and as number (percentage) for categorical variables. Differences between those children with one or more missing covariate and/or outcome value and those included in the complete case analysis (CCA) were tested using independentsamples $t$-test or Mann-Whitney $U$-test for numerical variables and chi-square test for categorical variables.

To analyse the associations between demographic and clinical characteristics and changes in CFQ- $R$ scores ( $T=12$ minus $T=0$ ), univariable and multivariable linear regression models were used. Dependent variables for the models were changes in CFQ-R total score and CFQ-R domain scores. All covariates (demographic and clinical characteristics) with a $p$ value $\leq 0.20$ from the univariable analyses were entered in the multivariable analysis.

To deal with missing data 50 complete datasets were created using multiple imputation (MI). The maximum number of iterations was set equal to 20 , where convergence was checked by inspecting the trace lines. The missing covariate and outcome values were 
imputed using all other variables as predictors, where the outcome variable was included to impute missing covariate values. The CCA, in which the patients with one or more missing covariate values were excluded from the analysis, was also performed and served as a sensitivity analysis.

Data were analysed with IBM SPSS Statistics for Windows (version 22.0. Armonk, NY). The multiple imputation part was performed using the MICE package in $\mathrm{R}$ (version 3.2.3). ${ }^{16}$

A post-hoc power analysis showed that with 49 cases, correlations between changes in CFQ-R scores and clinical variables of $\geq 0.30$ can be detected with a power of 0.80 and a significance level $\alpha$ of 0.05 , which was evaluated as sufficiently accurate for the purpose of this clinical study.

\section{Results}

Forty-nine patients participated in this 1-year prospective observational study. For the analysis of HRQoL, 39 of them (80\%) had no missing values (covariates and outcome parameters) and were included in the complete case analysis (CCA). Table 2.1 shows the baseline demographic and clinical characteristics of all 49 children and of the two subgroups, i.e. those without (CCA) and those with any missing covariates or outcome variables ('missing'). There were no significant differences between those in the CCA and those in the 'missing' group.

Table 2.1 Baseline characteristics of the 49 children

\begin{tabular}{lcccc}
\hline Characteristic & $\begin{array}{c}\text { Total cohort } \\
(\mathrm{n}=49)\end{array}$ & $\begin{array}{c}\text { CCA } \\
(\mathrm{n}=39)\end{array}$ & $\begin{array}{c}\text { 'missing' } \\
(\mathrm{n}=10)\end{array}$ & p-value \\
\hline Age, mean (SD) & $10.3(3.6)$ & $10.3(3.2)$ & $10.3(4.9)$ & 0.984 \\
Male gender, N (\%) & $31(63.3)$ & $26(66.7)$ & $5(50.0)$ & 0.329 \\
Pseudomonas aeruginosa at inclusion ${ }^{\text {\$, N (\%) }}$ & $15(30.6)$ & $12(30.8)$ & $3(30.0)$ & 0.962 \\
Pancreatic insufficiency, N (\%) & $32(65.3)$ & $25(64.1)$ & $7(70.0)$ & 0.727 \\
CFRD & $4(8.2)$ & $4(10.3)$ & $0(0.0)$ & 0.291 \\
Pathology of upper respiratory tract & $21(42.9)$ & $16(41.0)$ & $5(50.0)$ & 0.609 \\
FEV ${ }_{1}$ \% of predicted value, mean (SD) & $87.4(18.1)$ & $87.1(17.5)$ & $88.6(21.2)$ & 0.816 \\
BMI z score, mean (SD) & $0.14(0.83)$ & $0.17(0.81)$ & $0.05(0.94)$ & 0.675 \\
Number of PEx, median (IQR) & $2.0(1.0-4.0)$ & $2.0(1.0-4.0)$ & $1.0(0.0-3.3)$ & 0.384 \\
Number of medications ${ }^{\#}$, median (IQR) & $7.0(5.0-9.0)$ & $7.0(5.0-9.0)$ & $6.0(4.8-7.5)$ & 0.320 \\
Number of inhalation therapies, median (IQR) & $2.0(1.0-2.0)$ & $2.0(1.0-3.0)$ & $1.5(1.0-2.0)$ & 0.687 \\
\hline
\end{tabular}

$\mathrm{BMI}$, body mass index; CFRD, cystic fibrosis related diabetes; $\mathrm{FEV}_{1}$, forced expiratory volume in 1 second; FVC, forced vital capacity; PEx, pulmonary exacerbations. ${ }^{\$}$ treated because of presence in sputum ${ }^{\#}$ total number of medications minus total number of inhalation therapies $* p<0.05$ 


\section{Course of CFQ-R scores}

Table 2.2 shows the mean CFQ- $R$ total score and domain scores at $T=0, T=12$ and the change from baseline during follow-up. All scores improved significantly during the year except digestive symptoms. The mean total CFQ-R score was 68.6 at $\mathrm{T}=0$ and 76.6 at $\mathrm{T}=12$, a significant improvement of 8.0 points. Almost all domain scores also improved significantly, from 3.3 points (respiratory symptoms domain) to 31.7 points (physical functioning domain).

Table 2.2 CFQ-R total and domain scores at $\mathrm{T}=0$ and $\mathrm{T}=12$ and change over time

\begin{tabular}{lcccc}
\hline Characteristic & $\begin{array}{c}\mathrm{T}=0, \\
\text { mean (SD) }\end{array}$ & $\begin{array}{c}\mathrm{T}=12, \\
\text { mean (SD) }\end{array}$ & $\begin{array}{c}\text { Change (T=12 - } \\
\mathrm{T}=0), \text { mean (SD) }\end{array}$ & p-value \\
\hline CFQ-R total score, mean (SD) & $68.6(11.1)$ & $76.6(9.8)$ & $8.0(16.3)$ & $<0.001^{*}$ \\
CFQ-R physical functioning, mean (SD) & $48.5(31.8)$ & $80.2(16.6)$ & $31.7(41.3)$ & $<0.001^{*}$ \\
CFQ-R emotional functioning, mean (SD) & $76.3(12.0)$ & $82.1(11.0)$ & $5.8(11.2)$ & $<0.001^{*}$ \\
CFQ-R social functioning, mean (SD) & $61.5(17.0)$ & $73.3(17.8)$ & $11.8(27.5)$ & $<0.001^{*}$ \\
CFQ-R body image, mean (SD) & $82.0(21.2)$ & $91.6(10.8)$ & $9.6(19.2)$ & $<0.001^{*}$ \\
CFQ-R eating disturbances, mean (SD) & $70.5(17.9)$ & $76.5(26.5)$ & $6.0(24.0)$ & $<0.001^{*}$ \\
CFQ-R treatment burden, mean (SD) & $61.6(20.6)$ & $69.6(24.7)$ & $8.0(36.6)$ & $<0.001^{*}$ \\
CFQ-R respiratory symptoms, mean (SD) & $79.3(14.6)$ & $82.6(12.0)$ & $3.3(16.0)$ & $<0.001^{*}$ \\
CFQ-R digestive symptoms, mean (SD) & $69.5(23.2)$ & $68.7(24.6)$ & $-0.8(32.9)$ & 0.211 \\
\hline
\end{tabular}

CFQ-R, cystic fibrosis questionnaire-revised; * $p<0.05$

\section{Associations with change in CFQ-R total score}

The $\mathrm{Ml}$ analyses showed that, after correction for the other covariates, only age at baseline had a strong longitudinal association with change of CFQ-R total score in one year (Table 2.3). The estimate (B) indicates that with every year a child gets older, the mean change from baseline in CFQ-R total score decreased with 2.853. The relationship between PEx and the change in CFQ-R total score was of borderline significance $(p=0.065)$. Gender, BMI $z$ score, pancreas insufficiency at $T=0$, number of medications during the study, CFRD at $T=0$, pathology of the upper respiratory tract at $T=0$, and CFR total score at $\mathrm{T}=0$ were not included in the $\mathrm{Ml}$ (all $\mathrm{p}$-values from univariable analyses were $\geq 0.20$ ). Similar results were found in de CCA. No correlation between the change in $\mathrm{HRQoL}$ and the change in $\mathrm{FEV}_{1}$ was found (Pearson correlation coefficient $\mathrm{r}=0.036$, $\mathrm{p}=0.83$ ). 
Table 2.3 Associations between demographic/clinical variables and changes from baseline in CFQ-R total score using multivariable linear regression analysis

\begin{tabular}{lcc}
\hline Covariate & $\mathrm{B}(\mathrm{Cl})$ & $\mathrm{p}$-value \\
\hline Age at T=0 & $-2.853(-3.915,-1.791)$ & $<0.001^{*}$ \\
FEV ${ }_{1} \%$ pred at T=0 & $0.030(-0.197,0.256)$ & 0.797 \\
Number of PEx during study & $-1.839(-3.790,0.113)$ & 0.065 \\
Colonisation with Pseudonomas aeruginosa at T=0 & $-5.527(-13.985,2.931)$ & 0.200 \\
Number of inhalation therapies during study & $0.186(3.532,3.903)$ & 0.922 \\
\hline
\end{tabular}

$\mathrm{FEV}_{1} \%$ pred, forced expiratory volume in 1 second as percentage of predicted; PEx, pulmonary exacerbations. $\$$ treated because of presence in sputum, ${ }^{*} p<0.05$

Figure 2.1 shows the association between age at baseline and CFQ-R total scores of the CCA.

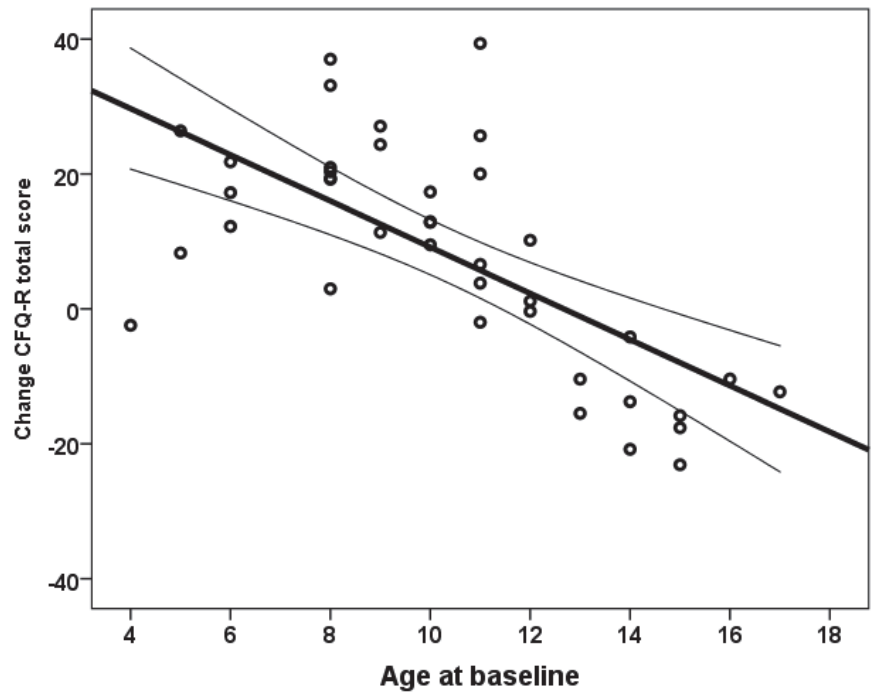

Figure 2.1 Association between age at baseline and change in CFQ-R total scores (regression line and $95 \% \mathrm{Cl}$ )

\section{Associations with change in separate CFQ-R domain scores}

In the multivariable regression models of the separate CFQ-R domains, increase in age was consistently associated with worsening of physical functioning and social functioning domain scores, treatment burden score, and respiratory symptoms score (Table 2.4). Of the other covariates, the number of PEx was independently associated with increasing treatment burden score, whereas the total number of (non-inhalation) therapies was associated with worsening of physical functioning domain score. In contrast, 
multivariable regression models did not show significant associations with any covariate and changes in the domains of emotional functioning, eating disturbances, body image, and digestive symptoms.

Table 2.4 Associations between demographic/clinical variables and changes in CFQ-R domains (only results of multivariable analyses are shown)

\begin{tabular}{|c|c|c|c|c|}
\hline Covariate & $\begin{array}{l}\text { Physical functioning } \\
\text { (B, Cl, p-value) }\end{array}$ & $\begin{array}{l}\text { Social functioning } \\
\text { (B, Cl, p-value) }\end{array}$ & $\begin{array}{l}\text { Treatment burden } \\
\text { (B, Cl, p-value })\end{array}$ & $\begin{array}{c}\text { Respiratory } \\
\text { Symptoms } \\
\text { (B, Cl, p-value) }\end{array}$ \\
\hline Age at $\mathrm{T}=0$ & $\begin{array}{l}-3.766(-6.565 \\
-0.967) 0.008^{*}\end{array}$ & $\begin{array}{l}-4.188(-6.150 \\
-2.226)<0.001^{*}\end{array}$ & $\begin{array}{l}-6.995(-9.401 \\
-4.589)<0.001^{*}\end{array}$ & $\begin{array}{l}-1.450(-2.859 \\
-0.41) 0.044^{*}\end{array}$ \\
\hline $\mathrm{BMI} z$ score at $\mathrm{T}=0$ & $\begin{array}{c}0.102(-10.576 \\
10.780) 0.985\end{array}$ & $\begin{array}{l}1.531(-7.047 \\
10.137) 0.727\end{array}$ & a) & $\begin{array}{c}-4.280(-10.301 \\
1.742) \\
0.163\end{array}$ \\
\hline $\mathrm{FEV}_{1} \%$ pred at $\mathrm{T}=0$ & $\begin{array}{c}0.120(-0.400 \\
0.640) 0.650\end{array}$ & a) & a) & a) \\
\hline Number of PEx during study & $\begin{array}{c}-3.819(-8.092 \\
0.453) 0.080\end{array}$ & $\begin{array}{c}-2.352(-5.748 \\
1.044) \\
0.175\end{array}$ & $\begin{array}{l}-4.466(-8.821 \\
-0.111) 0.044^{*}\end{array}$ & a) \\
\hline Pancreas insufficiency at $\mathrm{T}=0$ & & $\begin{array}{c}-11.219(-24.839 \\
2.402) \\
0.106\end{array}$ & a) & a) \\
\hline $\begin{array}{l}\text { Number of medications during } \\
\text { study }{ }^{\#}\end{array}$ & $\begin{array}{l}-4.097(-7.254 \\
-0.940) 0.011^{*}\end{array}$ & a) & a) & a) \\
\hline $\begin{array}{l}\text { Number of inhalation therapies } \\
\text { during study }\end{array}$ & $\begin{array}{c}1.079(-7.107 \\
9.265) 0.796\end{array}$ & a) & $\begin{array}{c}0.633(-6.308 \\
7.574) 0.858\end{array}$ & a) \\
\hline CFRD at $\mathrm{T}=0$ & $\begin{array}{c}-7.219(-38.890 \\
24.452) 0.655\end{array}$ & a) & a) & a) \\
\hline $\begin{array}{l}\text { Pathology of upper respiratory } \\
\text { tract at } T=0\end{array}$ & a) & $\begin{array}{c}-7.758(-21.648 \\
6.133) 0.274\end{array}$ & a) & $\begin{array}{l}9.074(-0.271 \\
18.419) 0.057\end{array}$ \\
\hline CFQ-R domain score at $\mathrm{T}=0$ & $\begin{array}{l}-1.396(-2.080 \\
-0.711)<0.001^{*}\end{array}$ & a) & a) & $\begin{array}{c}-0.297(-0.701 \\
0.107) 0.149\end{array}$ \\
\hline
\end{tabular}

BMI, body mass index; CFRD, cystic fibrosis related diabetes; CFR, cystic fibrosis questionnaire-revised; $\mathrm{FEV}_{1} \%$ pred, forced expiratory volume in 1 second as percentage of predicted; PEx, pulmonary exacerbations. \# total number of medications minus total number of inhalation therapies; a) not included in multivariable analyses ( $p$-values from univariable analyses were $\geq 0.20$ ); ${ }^{*} p<0.05$

\section{Discussion}

In this 1-year observational study, we investigated longitudinal associations between clinical and treatment variables with changes in HRQoL in children with CF. Overall, CFQ-R total score and all domain scores, except the digestive symptom score, improved significantly during 1 year. An older age was the most important determinant of a deterioration in CFQ-R total score and in several domain scores, whereas the CFQ-R total score improved in most children $<12$ years. Furthermore, PEx were significantly related to an increase in treatment burden score, and the total number of non-inhalation therapies correlated with a deterioration of the physical functioning domain score during 1 year. 
To our knowledge, this is the first longitudinal non-intervention study in children with CF to investigate the impact of clinical and treatment variables on change in HRQoL. We found significant improvements in CFQ-R total scores as well as most domain scores. We speculate that merely participating in an intensive study like the present one, improves HRQoL because of the extra attention that patients get, the extra contacts with the nurses and physicians of the CF team, and maybe also a better treatment adherence during the study. An alternative explanation for the main findings (Figure 2.1) may be a better coping with the disease in the course of years after birth (during school-age) and the problems related to CF in teenagers. It is interesting to perform in depth/focus interviews with parents and children with CF to get a better idea about underlying reasons for changes in HRQoL. The drop in HRQoL in children of 12 years and over may be the consequence of the increasing disease severity and treatment intensity, as reflected by the scores of the treatment burden domain and the respiratory symptom domain. Our results are in accordance with Abbott et al. who showed a significant deterioration of all CFQ-R domain scores in adolescents and adults during a decade of follow-up (-6.0 to -15.9 points). ${ }^{17}$ In children (6-13 years of age), Sawicki et al. found a significant increase in respiratory symptom score over 1 year but no significant changes in the other domains. ${ }^{10}$ In adults, Dill et al. found that although individual variation exists, overall there was no significant change in physical HRQoL during 21 months of follow-up. ${ }^{18}$ However, there were significant time trends in three psychosocial domains: treatment burden (improvement), emotional functioning (improvement), and social functioning (deterioration). ${ }^{18}$

Others also found an effect of age on HRQoL. Hegarty et al. demonstrated that children aged 6-13 years scored significantly better than those aged 14-18 for 'emotional state', 'body image' and 'treatment burden'. ${ }^{6}$ Moreover, a large European study in healthy children found a gradual decrease in HRQoL from childhood into adolescence. ${ }^{19}$ Abbott et al. evaluated the relationship between demographic and clinical variables and HRQoL during a 12-year period in adolescents and adults. In this study the importance of advancing age as predictor of HRQOL was confirmed. ${ }^{20}$ Especially in children with CF, not much is known about 'normal' CFQ-R scores. The HRQoL Outcomes Group warns about the difficulty of interpreting changes in CFQ- $R$ scores; there is no minimal clinically important difference known for the CFQ-R scores except for the respiratory symptom domain. ${ }^{13,21}$ Tibosch et al. found that the majority of healthy children do not reach maximum scores on many domains of the CFQ-R. ${ }^{22}$ Moreover, they found a heterogeneity of scores between the different domains and there were differences according to age. ${ }^{22}$ This implies normal psychosocial development and puberty should be taken into account when interpreting HRQoL especially in childhood and adolescence. ${ }^{22}$ 
We hypothesised that pulmonary exacerbations and lung function decline would be related to a deterioration of CFQ-R respiratory health domains. PEx were significantly related to an increase in treatment burden score but not with respiratory health domains or other domains in our study. Dill et al. showed that PEx were associated with lower CFQ-R scores of all domains in adults. ${ }^{18}$ In our study there was a positive timetrend in HRQoL, this might be the reason why we did not find an effect of PEx. Besides, we found no significant influence of $\mathrm{FEV}_{1}$ \%pred on any CFQ-R domain. A longitudinal study during 12 years showed that a decrease in lung function was associated with a decrease in HRQoL in adolescents and adults. ${ }^{17}$ We did not find this association which could be due to the relatively preserved and stable $\mathrm{FEV}_{1} \%$ pred during follow-up of only 1 year.

Furthermore, we speculated that CFQ-R treatment burden scores would be influenced by the number of (inhalation/nebulisation) therapies. However, we found no significant association between number of medications (inhalation as well as non-inhalation) and treatment burden scores. Ziaian et al. also found no significant relationship between treatment time (dependent on number of treatments) and HRQoL (measured with a the Child Health Questionnaire, a non-disease specific tool) of children with CF. ${ }^{23}$ Moreover, Sawicki et al. investigated treatment complexity (based on daily frequency, duration and ease of administration of chronic medications) and found that changes in treatment complexity were not associated with worsening treatment burden scores in children and adolescents. ${ }^{10}$ These findings are in contrast with a study in adults, where using 2 or more nebulised medications was significantly associated with increased treatment burden. ${ }^{24}$ However, we found that PEx were significantly related to an increase in treatment burden score, which probably implies that a temporary increase in number of medications and/or treatment time due to the exacerbation does matter.

The strengths of our study are the longitudinal study design; the focus on children only; and assessing HRQoL in a non-interventional study. Although the power analysis showed that clinically meaningful correlations could be detected with this relatively small sample size, it is still a limitation, for example, sub analyses for different age groups were not possible. Another limitation is the presence of missing data, in 10 of the 49 children one or more covariate or outcome variable was missing. We used multiple imputation to overcome this problem, which assumes the data to be missing at random. In this study group, the percentage of children with pancreas insufficiency (65\%) was lower than in the national Dutch cohort (80-90\% pancreas insufficiency). The results of this study may not hold for children with Burkholderiacepacia or MRSA as they were not included in this study. Although statistically significant improvements were observed in most CFQ-R domain scores over time, these changes may not be clinically meaningful as MCID of most HRQoL scores is unknown. 
The clinical implication of our study is that age and puberty have impact on HRQoL. Longitudinal changes in HRQoL in children with CF are relevant and HRQoL may therefore at least be included in the annual clinical evaluation of patients. It is worthwhile to repeat the study in a larger cohort and to assess more background information about experiencing a better or worse HRQoL, for instance by focus interviews. Besides, strategies to improve HRQoL in children with CF are very important, particularly in teenagers.

In conclusion, an older age is by far the most important variable related to a deterioration in HRQoL in children with CF. Besides, PEx and number of inhalation therapies were related to treatment burden and physical functioning. This means physicians should focus on HRQoL in adolescents, and develop strategies how to preserve or even improve HRQoL in this age group. 


\section{References}

1. Quon BS, Aitken ML. Cystic fibrosis: what to expect now in the early adult years. Paediatr Respir Rev. 2012;13(4):206-14.

2. Royce FH, Carl JC. Health-related quality of life in cystic fibrosis. Curr Opin Pediatr. 2011;23(5):535-40.

3. Goss CH, Quittner AL. Patient-reported outcomes in cystic fibrosis. Proc Am Thorac Soc. 2007;4(4): 378-86.

4. Habib AR, Manji J, Wilcox PG, Javer AR, Buxton JA, Quon BS. A systematic review of factors associated with health-related quality of life in adolescents and adults with cystic fibrosis. Ann Am Thorac Soc. 2015;12(3):420-8.

5. Quittner AL, Buu A, Messer MA, Modi AC, Watrous M. Development and validation of The Cystic Fibrosis Questionnaire in the United States: a health-related quality-of-life measure for cystic fibrosis. Chest. 2005;128(4):2347-54.

6. Hegarty M, Macdonald J, Watter P, Wilson C. Quality of life in young people with cystic fibrosis: effects of hospitalization, age and gender, and differences in parent/child perceptions. Child Care Health Dev. 2009;35(4):462-8.

7. Quittner AL, Sawicki GS, McMullen A, Rasouliyan L, Pasta DJ, Yegin A, et al. Erratum to: Psychometric evaluation of the Cystic Fibrosis Questionnaire-Revised in a national, US sample. Qual Life Res. 2012; 21(7):1279-90.

8. Casier A, Goubert L, Theunis M, Huse D, De Baets F, Matthys D, et al. Acceptance and well-being in adolescents and young adults with cystic fibrosis: a prospective study. J Pediatr Psychol. 2011;36(4): 476-87.

9. Klijn PH, van Stel HF, Quittner AL, van der Net J, Doeleman W, van der Schans CP, et al. Validation of the Dutch cystic fibrosis questionnaire (CFQ) in adolescents and adults. J Cyst Fibros. 2004;3(1):29-36.

10. Sawicki GS, Rasouliyan L, McMullen AH, Wagener JS, McColley SA, Pasta DJ, et al. Longitudinal assessment of health-related quality of life in an observational cohort of patients with cystic fibrosis. Pediatr Pulmonol. 2011;46(1):36-44.

11. Smyth AR, Bell SC, Bojcin S, Bryon M, Duff A, Flume P, et al. European Cystic Fibrosis Society Standards of Care: Best Practice guidelines. J Cyst Fibros. 2014;13 Suppl 1:S23-42.

12. Miller MR, Hankinson J, Brusasco V, Burgos F, Casaburi R, Coates A, et al. Standardisation of spirometry. Eur Respir J. 2005;26(2):319-38.

13. Quittner AL, Modi AC, Wainwright C, Otto K, Kirihara J, Montgomery AB. Determination of the minimal clinically important difference scores for the Cystic Fibrosis Questionnaire-Revised respiratory symptom scale in two populations of patients with cystic fibrosis and chronic Pseudomonas aeruginosa airway infection. Chest. 2009;135(6):1610-8.

14. CBO. Richtlijn diagnostiek en behandeling van cystic fibrosis. 2007.

15. Flume PA, Mogayzel PJ, Jr., Robinson KA, Goss CH, Rosenblatt RL, Kuhn RJ, et al. Cystic fibrosis pulmonary guidelines: treatment of pulmonary exacerbations. Am J Respir Crit Care Med. 2009;180(9):802-8.

16. van Buuren S, Groothuis-Oudshoorn K. mice: Multivariate Imputation by Chained Equations in R. Journal of Statistical Software. 2011;45(3):1-67.

17. Abbott J, Hurley MA, Morton AM, Conway SP. Longitudinal association between lung function and health-related quality of life in cystic fibrosis. Thorax. 2013;68(2):149-54.

18. Dill EJ, Dawson R, Sellers DE, Robinson WM, Sawicki GS. Longitudinal trends in health-related quality of life in adults with cystic fibrosis. Chest. 2013;144(3):981-9.

19. Michel G, Bisegger C, Fuhr DC, Abel T, group K. Age and gender differences in health-related quality of life of children and adolescents in Europe: a multilevel analysis. Qual Life Res. 2009;18(9):1147-57.

20. Abbott J, Morton AM, Hurley MA, Conway SP. Longitudinal impact of demographic and clinical variables on health-related quality of life in cystic fibrosis. BMJ Open. 2015;5(5):e007418.

21. Abbott J, Hart A, Havermans T, Matossian A, Goldbeck L, Barreto C, et al. Measuring health-related quality of life in clinical trials in cystic fibrosis. J Cyst Fibros. 2011;10 Suppl 2:S82-5.

22. Tibosch MM, Sintnicolaas CJ, Peters JB, Merkus PJ, Yntema JB, Verhaak CM, et al. How about your peers? Cystic fibrosis questionnaire data from healthy children and adolescents. BMC Pediatr. 2011;11:86. 
23. Ziaian T, Sawyer MG, Reynolds KE, Carbone JA, Clark JJ, Baghurst PA, et al. Treatment burden and healthrelated quality of life of children with diabetes, cystic fibrosis and asthma. J Paediatr Child Health. 2006;42(10):596-600.

24. Sawicki GS, Sellers DE, Robinson WM. High treatment burden in adults with cystic fibrosis: challenges to disease self-management. J Cyst Fibros. 2009;8(2):91-6. 

This chapter is embargoed at request

\section{Chapter}

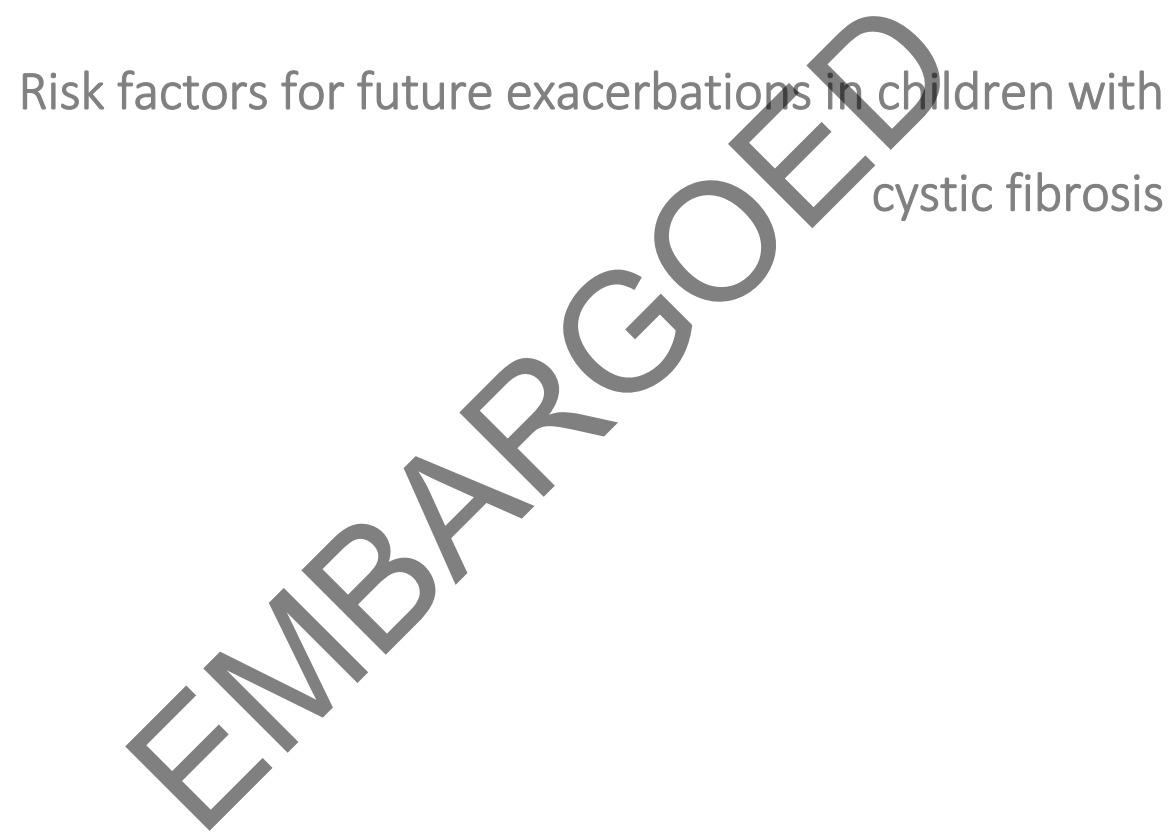

Marieke van Horck, Bjorn Winkens, Geertjan Wesseling, Vincent Gulmans, Han Hendriks, Quirijn Jöbsis, Edward Dompeling Submitted 


\section{Chapter 4}

Biomarkers in exhaled breath condensate are not predictive for pulmonary exacerbations in children with cystic fibrosis: results of a 1-year observational study

Marieke van Horck, Ariel Alonso, Geertjan Wesseling, Karin de Winter-de Groot, Wim van Aalderen, Han Hendriks, Bjorn Winkens, Ger Rijkers, Quirijn Jöbsis, Edward Dompeling PLoS One 2016;11(4):e0152156 


\section{Abstract}

\section{Background}

Cystic fibrosis (CF) is characterised by chronically inflamed airways, and inflammation even increases during pulmonary exacerbations. These adverse events have an important influence on the well-being, quality of life, and lung function of patients with CF. Prediction of exacerbations by inflammatory markers in exhaled breath condensate (EBC) combined with early treatment may prevent these pulmonary exacerbations and may improve the prognosis.

\section{Aim}

To investigate the diagnostic accuracy of a set of inflammatory markers in EBC to predict pulmonary exacerbations in children with CF.

\section{Methods}

In this 1-year prospective observational study, 49 children with CF were included. During study visits with an interval of 2 months, a symptom questionnaire was completed, EBC was collected, and lung function measurements were performed. The acidity of EBC was measured directly after collection. Inflammatory markers interleukin (IL)-6, IL-8, tumor necrosis factor $\alpha$ (TNF- $\alpha$ ), and macrophage migration inhibitory factor (MIF) were measured using high sensitivity bead based flow immunoassays. Pulmonary exacerbations were recorded during the study and were defined in two ways. The predictive power of inflammatory markers and the other covariates was assessed using conditionally specified models and a receiver operating characteristic curve (SAS version 9.2). In addition, k-nearest neighbors (KNN) algorithm was applied (SAS version 9.2).

\section{Results}

Sixty-five percent of the children had one or more exacerbations during the study. The conditionally specified models showed an overall correct prediction rate of $55 \%$. The area under the curve (AUC) was equal to 0.62. The results obtained with the KNN algorithm were very similar.

\section{Conclusion}

Although there is some evidence indicating that the predictors outperform random guessing, the general diagnostic accuracy of EBC acidity and the EBC inflammatory markers IL-6, IL-8, TNF- $\alpha$ and MIF is low. At present it is not possible to predict pulmonary exacerbations in children with CF with the chosen biomarkers and the method of EBC analysis. The biochemical measurements of EBC markers should be improved and other techniques should be considered. 


\section{Introduction}

Cystic fibrosis (CF) is the most common life-shortening genetic disease in the Caucasian population, caused by a mutation in the cystic fibrosis transmembrane conductance regulator (CFTR) gene. ${ }^{1}$ There are different types of mutations in this gene, all of them leading to a defective or absent CFTR protein. ${ }^{2}$ The CFTR protein is expressed in the apical membrane of epithelial cells, and a defective protein causes problems in organs with a secretory function such as the lungs, intestines and pancreas. Hence CF is a multisystem disease. Nevertheless the course of this progressive disease is predominantly determined by respiratory symptoms and complications. ${ }^{3}$ Respiratory deteriorations caused by alteration of the fragile homeostasis between airway pathogens and local host defenses are termed pulmonary exacerbations which are common in CF. ${ }^{4}$ Pulmonary exacerbations present clinically with a variety of symptoms such as increased cough, increased sputum production, increased dyspnea, decreased energy level and appetite, weight loss and decreases in lung function parameters. ${ }^{5}$ Currently these adverse events are treated with antibiotics when apparent, it is not yet possible to predict them. This means there is often a delay in starting treatment. An earlier treatment may positively influence the course of an exacerbation and improve long term prognosis in CF. However, to start treatment timely, it is necessary to detect pulmonary exacerbations at a very early stage.

Chronic inflammation of the airways is a major characteristic of CF. The inflammatory response is excessive and dysregulated, furthermore it plays an important role in both chronic bacterial infections and pulmonary exacerbations. ${ }^{6}$ The CF airway contains several pro-inflammatory mediators (like tumor necrosis factor alpha [TNF- $\alpha$ ], interleukin [IL]-6 and IL-8 and counter-regulatory molecules like IL-10). ${ }^{7}$ Macrophage migration inhibitory factor (MIF) is another pro-inflammatory cytokine important in the regulation of both the innate and acquired immune responses. ${ }^{8}$ The MIF polymorphism, associated with lower promotor activity, is associated with milder lung disease in F508del CF patients. ${ }^{9}$ Previous research in children with CF showed that inflammatory markers can be measured in exhaled breath condensate $(E B C) .{ }^{10}$ In contrast to bronchoalveolar lavage fluid, induced sputum and endobronchial biopsies, EBC is a completely non-invasive, safe and fast technique, not bearing any health risks, and also feasible in young children. ${ }^{11}$ In an earlier cross-sectional study in 98 children with CF and healthy controls, we found that inflammatory markers in EBC were able to indicate presence, severity and stability of CF disease. ${ }^{12}$ A pilot study of our group showed that IL6 , IL-8, IL-10, TNF- $\alpha$, and MIF, were predictive for exacerbations in children with CF. ${ }^{13}$ Therefore, we hypothesised that pulmonary exacerbations can be predicted at an early stage by assessing the inflammatory markers IL-6, IL-8, TNF- $\alpha$ and MIF in EBC. The aim of 
this study was to investigate the diagnostic accuracy of this set of inflammatory markers in $\mathrm{EBC}$ to predict pulmonary exacerbations in children with CF.

\section{Methods}

\section{Study design and setting}

For this 1-year observational cohort study (clinicaltrial.gov NCT01241890), children with CF between 5 and 18 years were recruited from three CF centers in the Netherlands (Maastricht, Amsterdam and Utrecht). Families were approached for the study by one of the pediatric pulmonologists during regular hospital visits and received written and oral information. The Medical Ethical Committee of the Maastricht University Medical Centre approved this study. Informed consent was signed by all parents and by children aged 12 years and older.

In the Maastricht University Medical Centre enrolment started in December 2011 and follow-up ended in May 2013. In the University Medical Centre Utrecht, the first children were enrolled in January 2012 and follow-up ended in June 2013. Finally, enrolment of children in the Amsterdam Medical Centre started in March 2012 and follow-up ended in August 2013.

Study visits were scheduled every 2 months during 1 year. To lessen the burden of the study and avoid loss to follow-up, we combined study visits with regular hospital visits as much as possible.

\section{Patients}

CF disease was defined as the presence of characteristic clinical features (persistent pulmonary symptoms, meconium ileus, failure to thrive, steatorrhea) in combination with an abnormal sweat test (chloride $>60 \mathrm{mM} / \mathrm{L}$ ) and/or two CF mutations. ${ }^{14}$

Exclusion criteria were: 1) severe cardiac abnormalities; 2) mental disability; 3) no technically adequate performance of measurements; 4) on waiting list for lung transplantation; 5) children colonised with Burkholderia Cepacia or Methicillin-Resistant Staphylococcus aureus; 6) participation in an intervention trial.

\section{Study parameters}

The occurrence of a pulmonary exacerbation was the primary outcome measure which was defined in two ways: first, according to the definition used in the EPIC trial ${ }^{15}$; and second, when the responsible pediatric pulmonologist started a course of therapeutic 
antibiotics (oral and/or intravenous) considering the clinical symptoms as an expression of a pulmonary exacerbation.

The presence of an exacerbation according to the EPIC trial was established by one of the major criteria alone, or two of the minor signs, and fulfillment of symptom duration (duration of sign/symptoms $\geq 5$ days or significant symptom severity) (Table 4.1 ).

Table 4.1 Definition of pulmonary exacerbation according to EPIC trial.

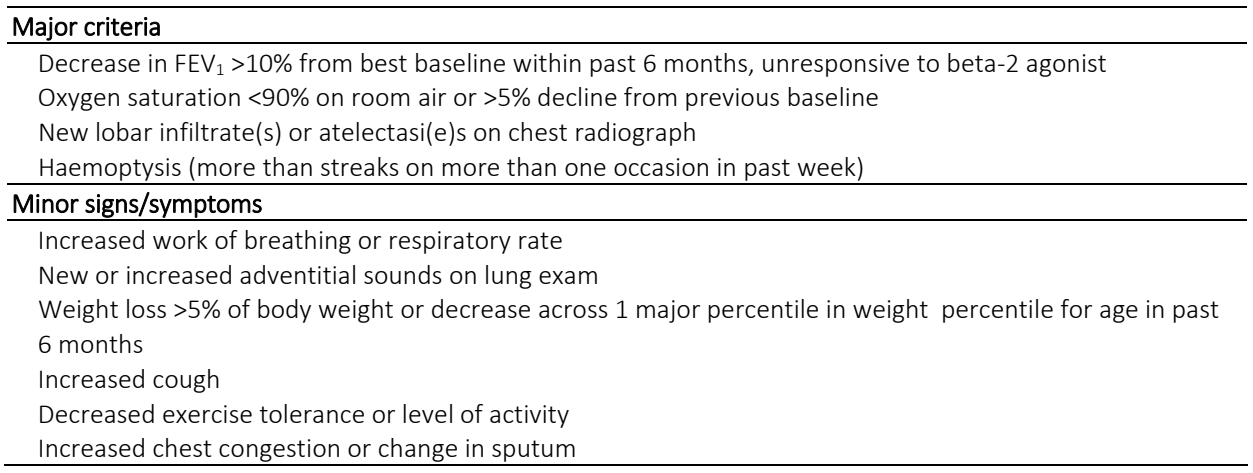

Treatment of pulmonary exacerbations during the study occurred in accordance with the Dutch Central Guidance Committee (CBO) guideline, ${ }^{16}$ which closely resembles European $^{14}$ and American CF guidelines. ${ }^{17}$

During every study visit, the same measurements took place: first, children completed a questionnaire, thereafter EBC collection took place, and finally, lung function measurements were performed. All measurements were carried out by extensively trained members of the research teams. The measurements were the same for all children.

\section{Questionnaire}

A questionnaire derived from the validated Dutch version of the cystic fibrosis questionnaire (CFQ-R) revised was used to evaluate symptoms. ${ }^{18}$ At 0,6 and 12 months the CFQ-R was completed entirely by all children. The CFQ-R consists of 35-50 items divided into 7-9 domains (depending on age): physical functioning, energy and wellbeing, emotional state, social limitations, role limitations, body image, eating disturbances, treatment burden, and embarrassment. Furthermore, overall health perception and three symptom scales are included: respiratory, digestive and weight. Items require either a frequency response on a 4-point scale ('all the time' to 'never'), a difficulty rating on a 4-point scale ('a lot of difficulty' to 'no difficulty'), a true-false rating on a 4-point scale, or the selection of a statement that describes the patient (on a 3- or 
4-point scale). The scores range from 0 to 100 with higher scores corresponding to higher quality of life.

\section{Exhaled breath condensate (EBC)}

Children breathed tidally for ten minutes, while wearing a nose-clip, through a mouthpiece connected to a two-way non-rebreathing valve (Hans Rudolph Inc, series 1420, Kansas City, USA) into a condenser system like described previously. ${ }^{19}$ The twoway valve and swan-neck tubing, served as a saliva trap to the condenser system. When the child ceased the procedure, EBC was collected by pushing the plunger downwards and sampling in a collection tube. The glass condenser was cooled using a countercurrent circulating ice-water pump. The cooling temperature was pre-set at $0.7^{\circ} \mathrm{C}$. EBC acidity was determined without deaeration immediately after collection (handheld $\mathrm{pH}$ meter, type $\mathrm{PH} 1000 \mathrm{H}$, and mic-microS7 pH sensor, VWR International B.V., NL, Germany). Condensate samples were snap-frozen using dry ice and stored at -80 degrees Celsius. Freeze-thaw cycles between collection and chemical analysis were avoided. To determine the levels of IL-6, IL-8, TNF- $\alpha$, and MIF a commercially available high sensitivity bead-based flow immunoassays were used and concentrations were calculated using BioPlex software version 5.1 (Millipore, St Charles, MO, USA). All multiplex immunoassays were performed in 96 well format $1.2 \mu \mathrm{m}$ filter bottom plates (Millipore, Amsterdam, The Netherlands) and a 12 point standard curve in duplicate was included on every plate. This standard curve consisted of the calibration fluids including two sequential dilutions to decrease the lower limit of quantification (LLOQ) of the assay. The median LLoQ's assessed during analysis of the EBC samples were for IL-6: $114 \mathrm{fg} / \mathrm{ml}$, IL-8: $25 \mathrm{fg} / \mathrm{ml}$, TNF- $\alpha$ : $107 \mathrm{fg} / \mathrm{ml}$ and MIF $3710 \mathrm{fg} / \mathrm{ml}$. In order to minimise interassay variation, positive and negative control samples were included. When fluorescence indices were below LLoQ, but above background, concentrations of samples were calculated by extrapolation. If concentrations could not be extrapolated, a concentration of $50 \%$ of the lowest measured concentration for the specific marker was imputed like described previously. ${ }^{20}$

\section{Lung function}

The Masterscreen Pneumo (Carefusion, Houten, The Netherlands) was used to measure dynamic lung function parameters, according to ATS/ERS standards. ${ }^{21}$ The highest values of three technically correct performed maneuvers were used for analysis. Recorded parameters were: forced expiratory volume in 1 second $\left(\mathrm{FEV}_{1}\right)$, forced vital capacity (FVC) and maximum expiratory flow at $50 \%$ of $F V C\left(M F_{50}\right)$, all expressed as a percentage of the predicted normal value. Static lung function indices (total lung capacity [TLC], 
residual volume [RV], functional residual capacity [FRC], expiratory reserve volume [ERV] and intrathoracic gas volume [ITGV]) were determined at 0 and 12 months by means of body plethysmography using the Masterscreen Body (Carefusion, Houten, The Netherlands).

\section{Covariates}

Gender, age, colonisation with Pseudomonas aeruginosa at inclusion, the use of prophylactic or therapeutic antibiotics, the use of corticosteroids, the time between visits and exacerbation at previous visit were considered as covariates. Information about the use of medication was checked at every study visit.

\section{Sample size}

Forty-nine children were included in this observational cohort study. Based on an assumed prevalence of an exacerbation of $50 \%$ and assuming the worst case sensitivity and specificity of 0.50 , the width of the confidence interval for sensitivity and specificity would be $0.4(0.3-0.7)$.

\section{Statistical data analysis}

For the statistical data analysis, SAS software package version 9.2 was used. To assess the prediction capacity of the biomarkers, a form of conditionally specified models, the so-called transition models were used. In transition models a measurement in a longitudinal sequence is described as a function of previous outcomes and covariates. ${ }^{22}$ In this study the probability of a pulmonary exacerbation between the current and next visit was assessed using 2 conditional models. The first model (Model 1) included the biomarkers (IL-6, IL-8, TNF- $\alpha$ and MIF), pH of the EBC, lung function parameters (FEV $\mathrm{FEV}_{1} \%$ of predicted value, FVC and FVC\% of predicted value), the time between visits and the presence of exacerbation at previous visit as predictors. The second model (Model 2) included all the predictors of the first model and age, sex, colonisation with Pseudomonas aeruginosa at inclusion, ABPA at inclusion, use of prophylactic antibiotics and use of inhalation corticosteroids. The data set was divided into a training and validation data sets. The training data set, containing the information of 36 randomly selected children, was used to estimate the predictive models and the predictive performance of the models was evaluated using the information in de validation data set containing the information of the remaining 13 children. The predictive capability of the models was primarily evaluated using the area under the corresponding ROC-curves. Additionally, the percentage of correct predictions was assessed using the validation data set. 
Besides, the KNN algorithm was used to evaluate the predictive performance of the biomarkers in the validation data set using the information in the training data set. KNN is a non-parametric lazy learning algorithm. ${ }^{23}$ The training samples are vectors of predictors or covariates, each with a class label. The training phase of the algorithm consists only of storing the feature vectors and class labels of the training samples.

All 49 patients were included in the statistical analysis, despite loss to follow-up or exclusion during the study. The proportion of missing values was generally low (less than $3.5 \%$ ). The exception was $\mathrm{pH}$ that had about $7.6 \%$ of missing values. Only the presence of missing values in $\mathrm{pH}$ was considered for the construction of the predictive model, these missing values had no predictive value.

\section{Results}

\section{Patients}

Forty-nine children with CF were included in the study (Figure 4.1). One child was excluded after 10 months because of becoming a carrier of Methicillin-Resistant Staphylococcus aureus. Six out of the 49 children were lost to follow-up, mostly because of personal reasons $(n=5)$, or because of a mild adverse effect of inhaled tobramycin $(n=1)$. Data of the children who were lost to follow-up were included in the analysis ('intention to treat').

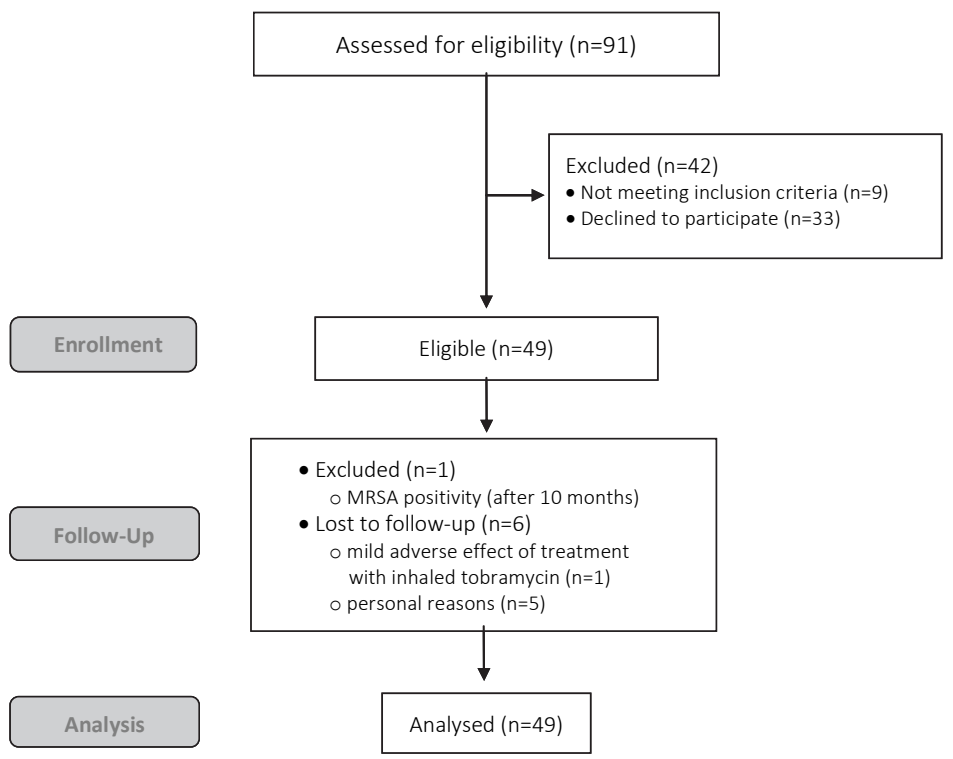

Figure 4.1 Consort flow diagram of the study 
The mean age of the children was 10.3 years, more boys participated (63.3\%) and the majority of the children had a homozygous DF508 mutation (73.5\%). The lung function was good with a mean $\mathrm{FEV}_{1}$ of $87.4 \%$ of predicted value. The nutritional status was good as reflected by the BMI and BMI-SDS (Table 4.2). All children were included in the statistical analysis. Eighty-four percent of the children were evaluated seven times, 2 of the drop-outs had only 1 measurement.

Table 4.2 Baseline characteristics

\begin{tabular}{lc}
\hline Characteristic & Total $(\mathrm{n}=49)$ \\
\hline Age, mean (SD) & $10.3(3.6)$ \\
Male sex, N (\%) & $31(63.3)$ \\
Homozygous DF508, N (\%) & $36(73.5)$ \\
Pseudomonas Aeruginosa at inclusion*, N (\%) & $15(30.6)$ \\
Allergic Bronchopulmonary Aspergillosis (ABPA) at inclusion, N (\%) & $2(4.0)$ \\
Pulmonary Exacerbations in 2 years before inclusion, N (\%) & $23(46.9)$ \\
BMI, median (IQR) & $16.8(16.0-18.1)$ \\
BMI-SDS, mean (SD) & $0.14(0.83)$ \\
FEV ${ }_{1} \%$ predicted value, mean (SD) & $87.4(18.1)$ \\
FEV 1 /FVC, mean (SD) & $0.80(0.1)$ \\
TLC\% predicted value, mean (SD) ( $=38)$ & $101.1(12.0)$ \\
RV\% predicted value, mean (SD) ( $=37)$ & $130.9(42.7)$ \\
Prophylactic antibiotics, N (\%) & $28(57.1)$ \\
Inhalation corticosteroids, N (\%) & $16(32.7)$ \\
\hline
\end{tabular}

* treated because of presence in sputum. BMI, body mass index; $\mathrm{FEV}_{1}$, forced expiratory volume in 1 second; FVC, forced vital capacity; RV, residual volume; TLC, total lung capacity

\section{Pulmonary exacerbations}

When the EPIC trial definition for a pulmonary exacerbation was used, 32 children (65\%) had 1 or more exacerbations during the study (Table 4.3). The prescription of therapeutic antibiotics by the pediatrician increased the percentage of children with exacerbation(s) to $88 \%$.

Table 4.3 Number and percentages of children with pulmonary exacerbations (EPIC trial definition) during study

\begin{tabular}{lcc}
\hline Number of pulmonary exacerbations & Frequency & Percentage \\
\hline 0 & 17 & 34.7 \\
1 & 12 & 24.5 \\
2 & 8 & 16.3 \\
3 & 6 & 12.2 \\
4 & 3 & 6.1 \\
5 & 3 & 6.1 \\
\hline
\end{tabular}




\section{Description of biomarkers in EBC}

There was a great variability in concentrations of measured biomarkers in EBC. The distribution of EBC acidity, and concentration of EBC biomarkers is given in Table 4.4.

Table 4.4 Acidity of EBC and concentrations of biomarkers in EBC

\begin{tabular}{lccccc}
\hline Variable & Minimum & Maximum & Median & Mean & SD \\
\hline $\mathrm{pH}$ & 0 & 7.2 & 6.0 & 5.95 & 0.59 \\
$\mathrm{IL}-6(\mathrm{fg} / \mathrm{ml})$ & 0.35 & 107.0 & 0.35 & 3.25 & 10.08 \\
$\mathrm{IL}-8(\mathrm{fg} / \mathrm{ml})$ & 0.45 & 4710.80 & 0.45 & 24.09 & 272.16 \\
$\mathrm{TNF}-\alpha(\mathrm{fg} / \mathrm{ml})$ & 1.90 & 132.60 & 1.90 & 13.38 & 25.06 \\
$\mathrm{MIF}(\mathrm{fg} / \mathrm{ml})$ & 92.53 & 291391.08 & 344.67 & 3141.64 & 17138.79 \\
\hline
\end{tabular}

\section{Diagnostic accuracy of biomarkers in EBC}

The best predictive results were obtained using the most complex Model 2. The estimated parameters for this model are provided in Table S4.1. This transition model correctly predicted $55 \%$ of the events (exacerbations or no exacerbations) in the validation dataset (Table 4.5). The prediction of an exacerbation was based on the probability of an exacerbation obtained from the prediction model with the probability $>0.5$ as a cut-off point.

Table 4.5 Translational model prediction of pulmonary exacerbation (EPIC trial definition)

\begin{tabular}{|c|c|c|c|}
\hline \multirow[t]{2}{*}{ Pulmonary exacerbation } & \multicolumn{2}{|c|}{ Prediction } & \multirow[b]{2}{*}{ Total, n (\%) } \\
\hline & No, $n(\%)$ & Yes, n (\%) & \\
\hline No & $39(44)$ & $8(9)$ & $47(53)$ \\
\hline Yes & $32(36)$ & $10(11)$ & $42(47)$ \\
\hline Total & $71(80)$ & $18(20)$ & $89(100)$ \\
\hline
\end{tabular}

However, the analysis of the ROC curve showed that the best predictions were obtained using a threshold of about 0.48 for the predictive probability of exacerbation, which led to a sensitivity of 0.70 and a specificity of 0.50 . Thus, in the best scenario, the model would detect $70 \%$ of the exacerbations but would fail to predict absence of an exacerbation in $50 \%$ of the time. The predictive model (with threshold 0.48 ) led to an area under the curve of 0.62 (Cl 0.49-0.75) (Figure 4.2). 


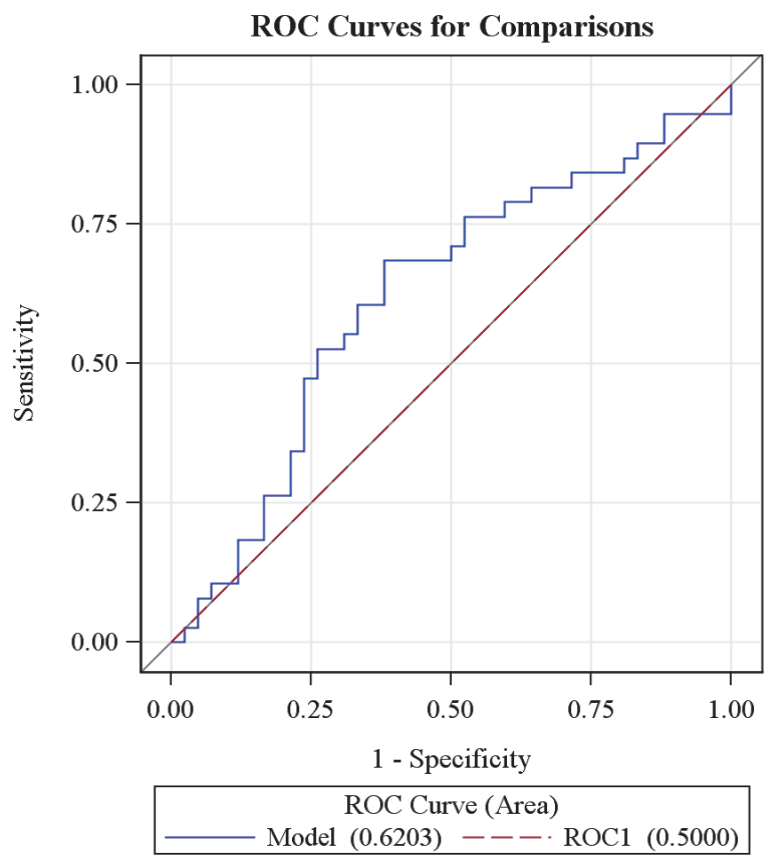

Figure 4.2 ROC-curve of predictive model of pulmonary exacerbations (EPIC trial definition)

The results obtained when the KNN algorithm was used were very similar. The KNN algorithm correctly predicted $59 \%$ of the events. If the second definition of a pulmonary exacerbation (when the responsible pediatric pulmonologist started a course of therapeutic antibiotics) was used, the overall correct prediction of the transitional model was $49 \%$ and the KNN algorithm predicted correctly $54 \%$ of the events.

\section{Discussion}

In this study, we assessed the diagnostic accuracy of a set of biomarkers in EBC to predict pulmonary exacerbations in children with CF. Overall, we found low predictive power of the EBC acidity and the inflammatory markers IL-6, IL-8, TNF $\alpha$ and MIF. Neither the definition of exacerbations (the EPIC trial definition versus the prescription of therapeutic antibiotics by the pediatrician) nor the statistical method (transition models versus KNN algorithm) did significantly affect the results. At present, it is not possible to predict pulmonary exacerbations in children with CF by means of the chosen biomarkers and methods. 
To our knowledge, only Horak et al performed a longitudinal study to investigate if an inflammatory marker, EBC nitrite, was helpful in monitoring lung disease in children with CF. They found that EBC nitrite could not predict pulmonary exacerbations or changes in pulmonary function or clinical and radiological scores. ${ }^{24}$ Others have assessed inflammatory markers in $\mathrm{EBC}$ before and after treatment of pulmonary exacerbations. Bodini et al found that IL-8 EBC levels decreased and EBC acidity increased after antibiotic treatment of a pulmonary exacerbation. ${ }^{25}$ In the study of Colombo et al., multiple biomarkers including IL-6, IL-8 and TNF $\alpha$ were measured in EBC before, during and after an acute exacerbation in adult CF patients. ${ }^{26}$ Although IL-8 was positively correlated with CRP at the start and after 15 days of treatment, in a multivariate regression analysis, no significant associations between biomarkers in $\mathrm{EBC}$ and clinical variables were found. ${ }^{26}$ Ojoo et al reported that EBC acidity was significantly lower during an exacerbation compared to stable disease. ${ }^{27}$ In addition, inflammatory markers have been studied in induced sputum. Liou et al. reported that high mobility group box-1 protein (HMGB-1), a novel inflammatory cytokine, predicted time-to first acute pulmonary exacerbation and number of future exacerbations within 5 years. $^{28}$ In summary, biomarkers in EBC and induced sputum have been studied but results are variable and not yet applicable to clinical practice.

An important strength of our study is its prospective and longitudinal character: we have followed 49 children with CF during one year. We obtained EBC every 2 months, and recorded all exacerbations to investigate the predictive power of inflammatory markers in EBC. Furthermore, we used advanced statistical methods, transitional models and KNN algorithm, which take recurrent and dependent findings into account, and in this way fits the longitudinal nature of our study. This in contrast to other predictive models that presume one condition or finding independently leads to one outcome. Another strength is the use of two definitions of a pulmonary exacerbation as primary outcome measure, which minimises information bias as a result of misclassification. If we had only used the stringent definition of the EPIC trial, we might have missed mild exacerbations, and incorrectly classified children as being stable when they were not. However, the use of two definitions accounts for heterogeneity of this primary outcome measure.

There are several explanations that could account for not being able to predict pulmonary exacerbations with the chosen biomarkers in EBC. First, in comparison with earlier studies, ${ }^{12,19,20}$ we had to switch to commercially available hypersensitive kits to analyze the EBC samples because the assay we used before was no longer available. The detection of cytokines and chemokines in EBC using this kit was lower than previously reported. Second, an explanation for the generally low concentrations of biomarkers in EBC may be the dilution of EBC as a medium. There are methods to correct for this dilution but each has specific disadvantages and therefore it is not recommended. ${ }^{11}$ 
Third, the results of the biochemical analysis showed a large variability in concentrations of the measured biomarkers. This occurred in children with exacerbations as well as in children without exacerbations. Possible explanations for this variability of concentrations could be the used assays are not developed or adjusted for EBC, and the antibodies lack sensitivity and specificity. ${ }^{29}$ In addition to the described factors influencing the biochemical analysis of the EBC samples, other aspects could have influenced our findings. The time frame between study visits might have been too long to detect relevant changes in biomarkers. In case we had collected EBC more frequently, it might have been easier to detect (small) changes in inflammatory markers. Besides, the interval between sampling of EBC and the start of a pulmonary exacerbation would have been shorter, which might have increased the chance to find an association between the increase in inflammation and the exacerbation. However, Sagel et al. reported biomarkers of inflammation to change over months rather than over days or weeks. ${ }^{30}$ Which is in line with the time for clinical decision making whether or not to treat pulmonary exacerbations. Additionally in a comparable study in 40 children with asthma, we found that EBC acidity and IL-5 assessed every 2 months were significantly related to the exacerbation rate. ${ }^{31}$ The choice of the biomarkers in the present study was based on the pathogenesis of $\mathrm{CF}$, the possibility to measure the markers in EBC and on previous findings of predictive ability of exacerbations in a pilot study of our group. ${ }^{13}$ Finally, our sample size was rather small, nonetheless, a larger group would probably not have improved our findings since not even a predictive trend was visible.

Although the collection of EBC is non-invasive, safe, fast and EBC originates directly from the (in this case chronically inflamed) airways, inflammatory markers in EBC currently do not contribute to the prediction of pulmonary exacerbations in children with CF. Future research should focus on development of EBC-specific sensitive assays for analysis of inflammatory markers in EBC that can cope with the strong dilution of EBC and the possible matrix effects. Furthermore, the potential of other techniques to analyze EBC like Nuclear Magnetic Resonance (NMR) spectroscopy, metabolomic profiling, gene expression or microbiome analyses should be explored.

In conclusion, we found that 2-monthly assessed inflammatory markers (IL-6, IL-8, TNF $\alpha$ and $\mathrm{MIF}$ ) in EBC and acidity of EBC were not able to predict pulmonary exacerbations in children with CF. This may well be due to methodological problems concerning the biochemical analysis of EBC. Considering chronic airway inflammation is a major hallmark of CF and pulmonary exacerbations negatively influence the prognosis, it would be a big step forward to be able to measure this airway inflammation (directly and noninvasively) and predict upcoming exacerbations. 


\section{References}

1. O'Sullivan BP, Freedman SD. Cystic fibrosis. Lancet. 2009;373(9678):1891-904.

2. Ratjen F. Recent advances in cystic fibrosis. Paediatr Respir Rev. 2008;9(2):144-8.

3. Zemanick ET, Harris JK, Conway S, Konstan MW, Marshall B, Quittner AL, et al. Measuring and improving respiratory outcomes in cystic fibrosis lung disease: opportunities and challenges to therapy. J Cyst Fibros. 2010;9(1):1-16.

4. Rosenfeld M, Emerson J, Williams-Warren J, Pepe M, Smith A, Montgomery AB, et al. Defining a pulmonary exacerbation in cystic fibrosis. J Pediatr. 2001;139(3):359-65.

5. Goss CH, Burns JL. Exacerbations in cystic fibrosis. 1: Epidemiology and pathogenesis. Thorax. 2007;62(4):360-7.

6. Chmiel JF, Berger M, Konstan MW. The role of inflammation in the pathophysiology of CF lung disease. Clin Rev Allergy Immunol. 2002;23(1):5-27.

7. Nichols DP, Chmiel JF. Inflammation and its genesis in cystic fibrosis. Pediatr Pulmonol. 2015;50 Suppl 40:S39-56.

8. Cooke G, Armstrong ME, Donnelly SC. Macrophage migration inhibitory factor (MIF), enzymatic activity and the inflammatory response. Biofactors. 2009;35(2):165-8.

9. Melotti $P$, Mafficini A, Lebecque P, Ortombina M, Leal T, Pintani E, et al. Impact of MIF gene promoter polymorphism on F508del cystic fibrosis patients. PLoS One. 2014;9(12):e114274.

10. Bodini A, D'Orazio C, Peroni D, Corradi M, Folesani G, Baraldi E, et al. Biomarkers of neutrophilic inflammation in exhaled air of cystic fibrosis children with bacterial airway infections. Pediatr Pulmonol. 2005;40(6):494-9.

11. van Mastrigt E, de Jongste JC, Pijnenburg MW. The analysis of volatile organic compounds in exhaled breath and biomarkers in exhaled breath condensate in children - clinical tools or scientific toys? Clin Exp Allergy. 2015;45(7):1170-88.

12. Robroeks CM, Rosias PP, van Vliet D, Jobsis Q, Yntema JB, Brackel HJ, et al. Biomarkers in exhaled breath condensate indicate presence and severity of cystic fibrosis in children. Pediatr Allergy Immunol. 2008;19(7):652-9.

13. Robroeks C, Jobsis Q, Braeckers R. Prediction of CF exacerbations by FeNO and non-invasive inflammatory markers in exhaled breath condensate. European Respiratory Society Congress; Berlin, Germany: European Respiratory Journal; 2008. p. 540s.

14. Smyth AR, Bell SC, Bojcin S, Bryon M, Duff A, Flume P, et al. European Cystic Fibrosis Society Standards of Care: Best Practice guidelines. J Cyst Fibros. 2014;13 Suppl 1:S23-42.

15. Treggiari MM, Rosenfeld M, Mayer-Hamblett N, Retsch-Bogart G, Gibson RL, Williams J, et al. Early antipseudomonal acquisition in young patients with cystic fibrosis: rationale and design of the EPIC clinical trial and observational study'. Contemp Clin Trials. 2009;30(3):256-68.

16. CBO. Richtlijn diagnostiek en behandeling van cystic fibrosis. 2007.

17. Flume PA, Mogayzel PJ, Jr., Robinson KA, Goss CH, Rosenblatt RL, Kuhn RJ, et al. Cystic fibrosis pulmonary guidelines: treatment of pulmonary exacerbations. Am J Respir Crit Care Med. 2009;180(9):802-8.

18. Klijn PH, van Stel HF, Quittner AL, van der Net J, Doeleman W, van der Schans CP, et al. Validation of the Dutch cystic fibrosis questionnaire (CFQ) in adolescents and adults. J Cyst Fibros. 2004;3(1):29-36.

19. Rosias PP, Robroeks CM, van de Kant KD, Rijkers GT, Zimmermann LJ, van Schayck CP, et al. Feasibility of a new method to collect exhaled breath condensate in pre-school children. Pediatr Allergy Immunol. 2010;21(1 Pt 2):e235-44.

20. Rosias PP, Robroeks CM, Kester A, den Hartog GJ, Wodzig WK, Rijkers GT, et al. Biomarker reproducibility in exhaled breath condensate collected with different condensers. Eur Respir J. 2008;31(5):934-42.

21. Miller MR, Hankinson J, Brusasco V, Burgos F, Casaburi R, Coates A, et al. Standardisation of spirometry. Eur Respir J. 2005;26(2):319-38.

22. Molenberghs G VG. Models for Discrete Longitudinal Data. 1 ed: Springer-Verlag New York; 2005.687 p.

23. Hastie T TR, Friedman J. The Elements of Statistical Learning. corrected edition ed. New York: Springer; 2003. 
24. Horak F, Jr., Moeller A, Singer F, Straub D, Holler B, Helbich TH, et al. Longitudinal monitoring of pediatric cystic fibrosis lung disease using nitrite in exhaled breath condensate. Pediatr Pulmonol. 2007;42(12):1198-206.

25. Bodini A, D'Orazio C, Peroni DG, Corradi M, Zerman L, Folesani G, et al. IL-8 and pH values in exhaled condensate after antibiotics in cystic fibrosis children. Int J Immunopathol Pharmacol. 2007;20(3):467-72.

26. Colombo C, Faelli N, Tirelli AS, Fortunato F, Biffi A, Claut L, et al. Analysis of inflammatory and immune response biomarkers in sputum and exhaled breath condensate by a multi-parametric biochip array in cystic fibrosis. Int J Immunopathol Pharmacol. 2011;24(2):423-32.

27. Ojoo JC, Mulrennan SA, Kastelik JA, Morice AH, Redington AE. Exhaled breath condensate pH and exhaled nitric oxide in allergic asthma and in cystic fibrosis. Thorax. 2005;60(1):22-6.

28. Liou TG, Adler FR, Keogh RH, Li Y, Jensen JL, Walsh W, et al. Sputum biomarkers and the prediction of clinical outcomes in patients with cystic fibrosis. PLoS One. 2012;7(8):e42748.

29. van Vliet D, Alonso A, Rijkers G, Heynens J, Rosias P, Muris J, et al. Prediction of asthma exacerbations in children by innovative exhaled inflammatory markers: results of a longitudinal study. PLoS One. 2015;10(3):e0119434.

30. Sagel SD, Chmiel JF, Konstan MW. Sputum biomarkers of inflammation in cystic fibrosis lung disease. Proc Am Thorac Soc. 2007;4(4):406-17.

31. Robroeks CM, van Vliet D, Jobsis Q, Braekers R, Rijkers GT, Wodzig WK, et al. Prediction of asthma exacerbations in children: results of a one-year prospective study. Clin Exp Allergy. 2012;42(5):792-8. 


\section{Supplemental table}

Table S4.1 Performance of acidity of EBC, inflammatory markers in EBC and covariates in prediction of pulmonary exacerbations

\begin{tabular}{lccc}
\hline Inflammatory markers & Estimate & $95 \% \mathrm{Cl}$ & $\mathrm{p}$-value \\
\hline $\mathrm{pH}$ & 0.6471 & $-0.3808,1.6750$ & 0.2172 \\
$\mathrm{IL}-6$ & 0.0259 & $-0.0036,0.0553$ & 0.0853 \\
$\mathrm{IL}-8$ & -0.0097 & $-0.0295,0.0101$ & 0.3377 \\
$\mathrm{TNF}-\alpha$ & 0.0054 & $-0.0167,0.0274$ & 0.6325 \\
$\mathrm{MIF}$ & -0.0001 & $-0.0002,0.0001$ & 0.5690 \\
Age & -0.0360 & $-0.3948,0.3227$ & 0.8440 \\
Gender & -0.0950 & $-102780,1.0879$ & 0.8749 \\
Pseudomonas aeruginosa at inclusion & -0.5893 & $-1.7274,0.5487$ & 0.3101 \\
Use of prophylactic antibiotics & -0.0167 & $-0.2305,0.1972$ & 0.8786 \\
Use of corticosteroids & -0.2569 & $-0.8263,0.3124$ & 0.3764 \\
FEV ${ }_{1} \%$ of predicted value & -0.0538 & $-0.1682,0.0605$ & 0.3563 \\
FVC\% of predicted value & -0.0001 & $-0.1115,0.1114$ & 0.9992 \\
Time between visit and exacerbation at previous visit & -0.0097 & $-0.1200,0.1007$ & 0.8635 \\
\hline
\end{tabular}



This chapter is embargoed at request

\section{Chapter 5}

Exhaled volatile organic compounds early detect pulmonary exacerbations in children with cystic fibrosis: results of a 1-yearobservational study

Marieke van Horck, Agnieszka Smolinska, Geertjan Wesseling, Karin de Winter-de Groot, Ilja de Vreede, Bjorn Winkens, Quirijn Jöbsis, Jan Dallinga, Edward Dompeling, Frederik-Jan van Schooten 


\section{Chapter 6}

Early detection of pulmonary exacerbations in children with cystic fibrosis by electronic home monitoring of symptoms and lung function

Marieke van Horck, Bjorn Winkens, Geertjan Wesseling, Dillys van Vliet, Kim van de Kant, Sanne Vaassen, Karin de Winter-de Groot, Ilja de Vreede, Quirijn Jöbsis, Edward Dompeling Accepted for publication, Scientific reports 


\section{Abstract}

\section{Background}

Pulmonary exacerbations (PEx) in cystic fibrosis (CF) are associated with an increased morbidity and even mortality. We investigated whether early detection of PEx in children with CF is possible by electronic home monitoring of symptoms and lung function.

\section{Methods}

During this 1-year prospective multi-centre study, 49 children with CF were asked to use a home monitor 3 times a week. Measurements consisted of a respiratory symptom questionnaire and assessment of forced expiratory volume in 1 second $\left(\mathrm{FEV}_{1}\right)$. Linear mixed-effects and multiple logistic regression analyses were used.

\section{Results}

In the 2 weeks before a PEx, the respiratory symptom score (RSS) of the home monitor increased $(p=0.051)$. The $\mathrm{FEV}_{1}$ as percentage of predicted $\left(\mathrm{FEV}_{1} \%\right.$ pred) did not deteriorate in the 4 weeks before a PEx. Nevertheless, the FEV ${ }_{1} \%$ pred at the start of exacerbation was significantly lower than the $\mathrm{FEV}_{1} \%$ pred in the non-exacerbation group (mean difference 16.3\%, $\mathrm{p}=0.012$ ). The combination of $\mathrm{FEV}_{1} \%$ pred and RSS had a sensitivity to predict an exacerbation of $92.9 \%(\mathrm{Cl} 75.0-98.8 \%)$ and a specificity of $88.9 \%$ (Cl 50.7-99.4\%).

\section{Conclusion}

The combination of home monitor $\mathrm{FEV}_{1} \%$ pred and RSS can be helpful to predict a PEx in children with CF at an early stage. 


\section{Introduction}

Pulmonary exacerbations in cystic fibrosis (CF) are important events, associated with an accelerated decline in lung function and an increased morbidity and even mortality. ${ }^{1}$ Prevention of pulmonary exacerbations (PEx) is one of the main goals in the management of CF. ${ }^{2}$ Currently, treatment of a PEx starts when a patient presents with an increase in (respiratory) complaints, a deterioration in lung function and/or weight loss. It often takes some time before a patient with more complaints seeks medical care. This patient delay may introduce a subsequent delay in starting antibiotic treatment, potentially resulting in a more severe course of the PEx, and a higher risk of permanent lung function loss.

There are some known risk factors for PEx in children, including frequency of previous PEx, a lower baseline forced expiratory volume in 1 e second $\left(\mathrm{FEV}_{1}\right)$, and female gender. ${ }^{3}$ However, in individual cases these factors do not help to decide when to start therapy timely. As PEx cannot be predicted reliably yet, there is a need for a method to detect PEx at an earlier stage. Electronic home monitoring may be useful to detect changes in lung function and respiratory complaints at an early stage. It provides the opportunity to assess symptoms and lung function on a daily or weekly basis. Data can be sent to the CF centre where they can be evaluated. In this way, disease deterioration and the occurrence of PEx may be detected earlier.

Data of electronic home monitoring in CF are scarce. ${ }^{4-6}$ Only one small study assessed whether early detection of PEx by home monitoring in adolescent patients with CF was possible. ${ }^{4}$ In children with asthma, we recently demonstrated that home monitoring is better able to detect cases with less well-controlled disease than a validated questionnaire during hospital visits. ${ }^{7}$

The aim of the present study was to test the hypothesis that electronic home monitoring of respiratory symptoms and lung function is a valuable tool to detect PEx in children with CF at an early stage.

\section{Methods}

\section{Study design and population}

Children with CF aged 5 to 19 years were included in this one year, multicentre, observational cohort study (clinicaltrial.gov NCT01241890). Children were recruited from three CF centres in the Netherlands (Maastricht, Utrecht and Amsterdam).

CF was defined as the presence of characteristic clinical features (persistent pulmonary symptoms, meconium ileus, failure to thrive, steatorrhea) in combination with an 
abnormal sweat test (chloride $>60 \mathrm{~mL}$ ) and/or two CF mutations. ${ }^{8}$ Exclusion criteria were: 1) severe cardiac abnormalities; 2) mental disability; 3) no technically adequate performance of lung function measurements; 4) on waiting list for lung transplantation; 5) children colonised with Burkholderia cepacia or Methicillin-Resistant Staphylococcus aureus; 6) participation in an intervention trial.

Ethical approval was obtained from the Medical Ethical Committee of the Maastricht University Medical Centre. Informed consent was signed by all parents, and by children aged 12 years and over. All methods were performed in accordance with the relevant guidelines and regulations.

\section{Study parameters}

For the period of one year, we surveyed the children by means of regular clinical visits every two months and thrice-weekly home monitoring of lung function and symptoms. Demographic information and medical history were collected at inclusion. During each clinical visit, changes in medication were reported and spirometry was performed. During the 1-year follow up, all PEx were recorded.

\section{Home monitoring}

All children received a handheld AM2 home monitor (CareFusion, Houten, The Netherlands). A prototype of this monitor was tested for accuracy, reproducibility and interdevice variability and appeared to meet the American Thoracic Society (ATS) standards for monitoring devices. ${ }^{9}$

Children were asked to use the home monitor 3 times a week at the same time of the day. By using the home monitor, children recorded the presence and severity of respiratory symptoms (cough, sputum and dyspnoea) digitally by answering 3 questions. The severity of symptoms was scored on a range from 0 (no complaints) to 3 (a lot of complaints). The respiratory symptom score (RSS) was defined as the sum of these three questions (range 0 to 9) and was used for the analysis. Subsequently, lung function measurements consisted of three forced vital capacity (FVC) manoeuvres with maximal effort. All children and parents were thoroughly instructed how to perform a correct FVC manoeuver. The mean $\mathrm{FEV}_{1}$ as $\%$ of predicted ( $\mathrm{FEV}_{1} \%$ pred) of each day was calculated and used for the analysis.

RSS and lung function measurements were stored in the device. The families were asked to transfer the data into a secured web-based portal (Avetana, GmbH, Hoechberg, Germany) once a week. Families who did not send their data weekly, received a reminder to increase adherence. 
Adherence to the home monitor was defined as completion of $70 \%$ of the maximum number of requested home monitor measurements over 1 year.

\section{Primary outcome: detection of PEx}

The primary outcome was the detection of a PEx, which was defined in two ways: first according to the definition used in the Early Pseudomonas Infection Control (EPIC) trial. ${ }^{10}$ The presence of a PEx was established by 1 of the major criteria alone, or 2 of the minor criteria, and fulfilment of symptom duration (duration of sign/symptoms $\geq 5$ days or significant symptom severity) (see Table $\mathbf{5 6 . 1}$ supplement). Second, when the responsible paediatric pulmonologist started a course of therapeutic antibiotics considering the clinical symptoms as an expression of a PEx.

PEx were treated according to the Dutch Central Guidance Committee (CBO) guideline, ${ }^{11}$ which resembles European (8) and American CF guidelines. ${ }^{12}$

\section{Statistical analysis}

Baseline characteristics were expressed as mean (standard deviation [SD]) or median (interquartile range [IQR]) where appropriate for numerical variables, and as number (percentage) for categorical variables.

We used the first PEx for the longitudinal analysis of FEV ${ }_{1}$ \%pred and RSS from 4 weeks before until the start of a PEx. If this PEx was within 4 weeks after inclusion, we used the subsequent PEx as long as the time between the end of the antibiotic course for the previous PEx and the start of the subsequent PEx was again at least 4 weeks.

A linear mixed-effects model was used to test differences in home monitor data during 4 weeks prior to the selected PEx between patients with a PEx (exacerbation group) and patients without any PEx (no exacerbation group). The median number of days before the PEx in the exacerbation group was used as reference point $(t=0)$ for the no exacerbation group, measurements up to 4 weeks before this time point were used in the analysis. Group (exacerbation or no exacerbation), time to PEx in weeks ( $t=-4$ to $t=0$ ), and time*group were included as fixed factors. Other fixed factors were: centre, gender, age at inclusion (in years), Pseudomonas aeruginosa at inclusion, PEx in the two years before inclusion, and season, as these factors were expected to be related to PEx. For the random part of the model, different options were considered, i.e. only random intercept, or random intercept and slope (variance components or unstructured). The option with the smallest Akaike's information criterion (AIC) was selected. ${ }^{13}$ Sensitivity/robustness analyses were performed, in which the influence of the used definition of a PEx, inclusion of only the first PEx during the study, or changing the period before a PEx from 4 to 8 weeks, on the results was checked. 
In addition, multiple logistic regression analysis was used to study the effect of $\mathrm{FEV}_{1} \%$ pred and RSS from 4 weeks to 1 week before a PEx (or reference point in case of no PEx) on probability of obtaining a PEx. To be of predictive use, the week just before a PEx was excluded. The area under the ROC curve was used as a measure of prediction quality. As for optimal cut-off point of predicted probability, the Youden index was used, which maximises the sum of sensitivity and specificity. ${ }^{14}$ An internal validation was performed using a bootstrapping method (1000 bootstrapping samples), where the optimism in predictive quality of the model (AUC) due to overfitting was computed and adjusted for.

Data were analysed with IBM SPSS Statistics for Windows (version 22.0. Armonk, NY), while we used the R package entitled 'rms' for the internal validation of the prediction model (version 3.1-0. Vienna, Austria).

\section{Results}

\section{Patient Characteristics}

Forty-nine children (mean age 10.3 years) participated in this study. Patient characteristics are shown in Table 6.1.

Table 6.1 Baseline characteristics of study cohort

\begin{tabular}{lc}
\hline Characteristic & $\begin{array}{c}\text { Total cohort } \\
\text { (n=49) }\end{array}$ \\
\hline Age, mean (SD) & $10.3(3.6)$ \\
Male sex, N (\%) & $31(63)$ \\
Homozygous dF508, N (\%) & $36(74)$ \\
PEx in 2 years before inclusion, N (\%) & $23(47)$ \\
Pseudomonas aeruginosa at inclusion*, N (\%) & $15(31)$ \\
ABPA at inclusion*, N (\%) & $2(4)$ \\
BMI, median (IQR) & $16.8(16.0-18.1)$ \\
BMI-SDS, mean (SD) & $0.14(0.8)$ \\
FEV ${ }_{1} \%$ predicted value, mean (SD) & $87.4(18.1)$ \\
FVC \% predicted value, mean (SD) & $92.4(16.4)$ \\
FEV 1 FVC, mean (SD) & $0.8(0.1)$ \\
RV \% predicted value, mean (SD) & $130.9(42.7)$ \\
TLC \% predicted value, mean (SD) & $101.1(12.0)$ \\
Prophylactic antibiotics, N (\%) & $28(57)$ \\
Inhalation corticosteroids, N (\%) & $16(33)$ \\
\hline
\end{tabular}

* treated because of positive sputum culture. \# total n=37 (12 children did not perform static lung function). Abbreviations: ABPA, allergic bronchopulmonary aspergillosis; $\mathrm{BMI}$, body mass index; $\mathrm{FEV}_{1}$, forced expiratory volume in 1 second; FVC, forced vital capacity; PEx, pulmonary exacerbation; RV, residual volume; SD, standard deviation; TLC, total lung capacity. All $p>0.05$ 
As shown in Figure 6.1, 3 patients did not use the home monitor, 2 due to technical reasons, and 1 child dropped out before using the home monitor. Nine children were excluded from the analysis as no 4 weeks of home monitor data before a PEx were available in these children (e.g. due to an PEx within 4 weeks or because of missing data). Therefore, data of 37 patients could be analysed. There were no clinically relevant or statistically significant differences in baseline characteristics between children included or excluded from the analyses or between the exacerbation and the no exacerbation group.

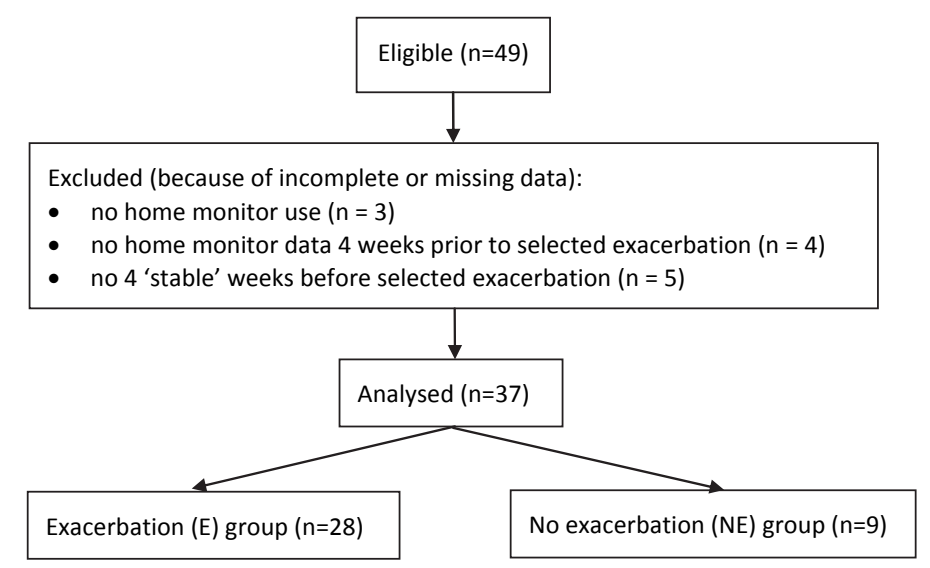

Figure 6.1 Flowchart of included study population

\section{Course of the $\mathrm{FEV}_{1} \%$ pred and RSS in exacerbation (E) and no exacerbation (NE) groups}

Twenty-eight children participated in the E group: data on the first and the subsequent PEx were used in 18 and 10 children respectively. The median time from inclusion to the selected PEx was 86 days. The NE group consisted of nine children who did not experience a PEx during the one-year study period.

In Figures $6.2 \mathrm{a}$ and $\mathrm{b}$, the course of the estimated mean $\mathrm{FEV}_{1} \%$ pred and estimated mean RSS in the 4 weeks before and after the onset of the PEx for both the E group and the NE group are demonstrated. 
$\mathrm{FEV}_{1} \%$ of predicted home monitor

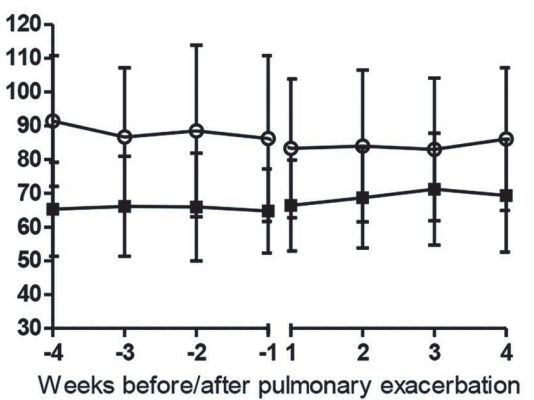

Respiratory Symptom Score

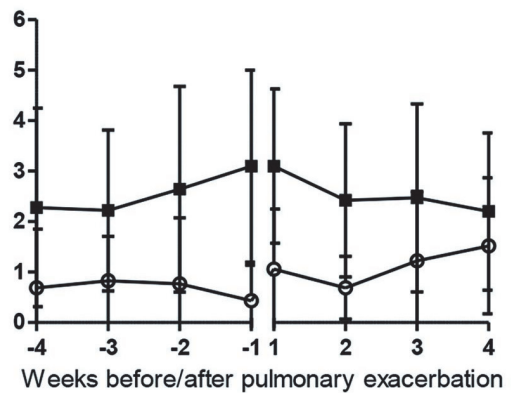

Figure 6.2 Course of the estimated mean (A) $\mathrm{FEV}_{1} \%$ pred or (B) respiratory symptom score 4 weeks before and after a pulmonary exacerbation for the E group ( $n=28$; filled squares) and NE group ( $n=9$; open circles). Bars represent corresponding SEs

\section{Difference in $\mathrm{FEV}_{1} \%$ pred and RSS between exacerbation and no exacerbation group}

In Table 6.2, the results of the mixed-effects model analysis are shown. The time trend for the $\mathrm{FEV}_{1} \%$ pred in the 4 weeks before exacerbation was not significant $(\mathrm{p}=0.650)$, although the $\mathrm{FEV}_{1} \%$ pred at the start of the PEx $(T=0)$ was significantly lower in the $E$ group compared to the NE group (mean difference $16.3 \%, \mathrm{p}=0.012$ ). The RSS showed a trend towards a significant increase in the weeks before exacerbation $(p=0.051)$. Compared to the FEV ${ }_{1} \%$ pred, the RSS at the start of the PEx was significantly worse in the E group compared to the NE group (mean difference 2.97 points on a scale of 0 to 9 , $p<0.001)$.

Table 6.2 Estimated means and difference in estimated means (at $t=0$ and time trend) between exacerbation and control group based on linear mixed-effects model ${ }^{a}$

\begin{tabular}{|c|c|c|c|c|c|c|c|c|}
\hline & & \multicolumn{3}{|c|}{ Estimated means (SE) } & \multicolumn{4}{|c|}{ Estimated mean difference $(95 \% \mathrm{Cl})$} \\
\hline & & $T=-4$ & $\mathrm{~T}=-2$ & $\mathrm{~T}=0$ & $\mathrm{~T}=0$ & $p$ & Time trend & $\mathrm{p}$ \\
\hline \multirow[t]{2}{*}{$\mathrm{FEV}_{1} \%$ pred } & E group & $\begin{array}{c}69.33 \\
(11.52)\end{array}$ & $\begin{array}{c}68.58 \\
(11.37)\end{array}$ & $\begin{array}{c}67.82 \\
(11.30)\end{array}$ & $\begin{array}{c}-16.30 \\
(-28.75,-3.85)\end{array}$ & 0.012 & $\begin{array}{c}0.067 \\
(-0.232,0.366)\end{array}$ & 0.650 \\
\hline & NE group & $\begin{array}{c}87.51 \\
(12.61)\end{array}$ & $\begin{array}{c}85.81 \\
(12.25)\end{array}$ & $\begin{array}{c}84.12 \\
(12.15)\end{array}$ & & & & \\
\hline \multirow[t]{2}{*}{ RSS } & E group & $\begin{array}{c}2.25 \\
(1.38)\end{array}$ & $\begin{array}{c}2.76 \\
(1.35)\end{array}$ & $\begin{array}{c}3.27 \\
(1.33)\end{array}$ & $\begin{array}{c}2.97 \\
(1.52,4.42)\end{array}$ & $<0.001$ & $\begin{array}{c}0.051 \\
(0.000,0.102)\end{array}$ & 0.051 \\
\hline & NE group & $\begin{array}{c}0.70 \\
(1.54)\end{array}$ & $\begin{array}{c}0.50 \\
(1.46)\end{array}$ & $\begin{array}{c}0.30 \\
(1.43)\end{array}$ & & & & \\
\hline
\end{tabular}

$\mathrm{E}$, exacerbation; $\mathrm{NE}$, no exacerbation; $\mathrm{FEV}_{1} \%$ predicted, forced expiratory volume in 1 second percentage of predicted; RSS, respiratory symptom score. ${ }^{a}$ Reference categories: site University Medical Centre Utrecht, female gender, age 10.3 years, exacerbations in 2 years before inclusion, Pseudomonas aeruginosa at inclusion, season autumn 
Sensitivity/robustness analyses showed similar results when only PEx according to the EPIC trial definition were used, when only the first PEx during the study were included, or when the time period before a PEx was increased to 8 weeks.

\section{Prediction model of PEx}

From the above mentioned data and analysis, it was evident that a lower FEV $\mathrm{F}_{1} \%$ pred and a higher RSS preceded a PEx. Therefore, these parameters were used as independent variables in a multiple logistic regression analysis in order to study the effect on the probability of obtaining a PEx. We used the mean values over the period from 4 weeks up to 1 week before a PEx. Both the mean $\mathrm{FEV}_{1} \%$ pred and the mean RSS appeared to be independent predictors of PEx and the combination resulted in an area under the ROC curve of 0.87 (Figure 6.3A).

The optimum cut-off point, i.e. the one which maximises the sum of sensitivity and specificity (Youden Index), gave a sensitivity of $92.9 \%$ (Cl 75.0-98.8\%) and a specificity of 88.9\% ( $\mathrm{Cl} 50.7-99.4 \%$ ) for the combination of the mean $\mathrm{FEV}_{1} \%$ pred and the mean RSS of the home monitor. A combination threshold of mean $\mathrm{FEV}_{1} \%$ pred lower than $77 \%$ and mean RSS higher than 1.8 was predictive for a PEx (Figure 6.3B).

A

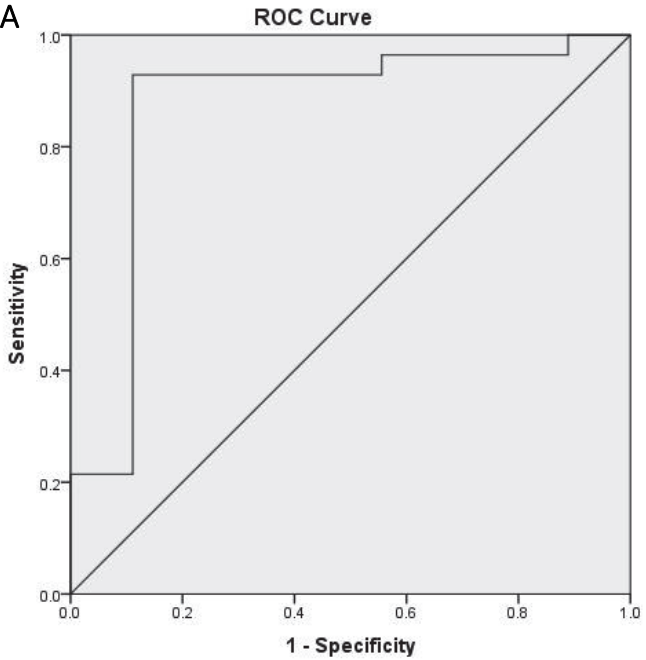

B

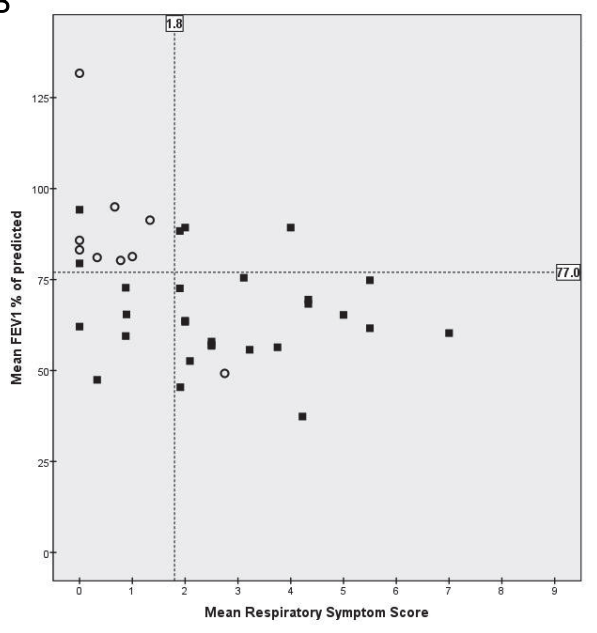

Figure 6.3 (A) ROC curve of predictive model of pulmonary exacerbations and (B) combination threshold of mean $\mathrm{FEV}_{1} \%$ pred and mean RSS to predict a PEx. Filled squares correspond to children in the exacerbation group, open circles correspond to children in the no exacerbation group 


\section{Adherence to the home monitor}

Fifty-four \% of the children demonstrated good adherence to the home monitor. The median percentage of completed data compared to the total amount of requested data of all children was $77 \%$ (IQR 45\%-88\%).

\section{Discussion}

This study in children with CF showed an increase in the RSS from the home monitor, especially in the 2 weeks before an exacerbation. Moreover, the RSS was already worse 4 weeks before a PEx in the E group compared to the NE group. In contrast, no deterioration in $\mathrm{FEV}_{1}$ \%pred in the 4 weeks before a PEX was found, although the $\mathrm{FEV}_{1} \%$ pred at the start of the exacerbation was lower in the exacerbation group compared to the NE group. The combination of the mean $\mathrm{FEV}_{1} \%$ pred and mean RSS of 4 weeks to 1 week before a PEx resulted in good sensitivity and specificity to predict an exacerbation in our study. To improve long term prognosis of children with $C F$, early detection of PEx is essential. Electronic home monitoring of symptoms and lung function seems a promising tool to detect PEx in children with CF at an early stage. However, a validation study in a larger cohort should be performed.

While the $\mathrm{FEV}_{1}$ \%pred and the RSS differed significantly between the E group and the NE group, no further decrease in $\mathrm{FEV}_{1}$ \%pred was found in the weeks or days preceding a PEx. In clinical practice physicians sometimes notice an acute decrease in lung function but more often there appears to be a slow decrease during weeks or even months when patients present themselves with increased symptoms. Lung function deterioration in CF is related to ongoing chronic airway inflammation, thick and sticky mucus with plugging and atelectasis, injury to the airways with bronchiectasis and fibrosis, which is triggered by viral infections, bacterial overgrowth, and bacterial infections/exacerbations. ${ }^{15}$ Although symptoms were already worse in the 4 weeks preceding the exacerbation, further deterioration was observed in the 2 weeks before the PEx. In this way, symptoms seem to be a more sensitive and acute indicator of a PEx than lung function. This is in accordance with exacerbations in patients with COPD, where increased symptoms and a patient's reported diagnosis are more important than lung function. ${ }^{16}$

Adherence to the home monitor could be further optimised: $77 \%$ of the requested data were gathered by the children and the parents, and $54 \%$ of the children had good or optimal adherence (according to the current definition of assessing at least assessing $70 \%$ of the data). So far, we are not informed about the minimal or the optimal monitor frequency. It may be that with $>70 \%$ of the requested monitor data, still a valuable monitoring and prediction of exacerbations is possible. An explanation for the missing 
data may be the high burden of disease that children with CF already experience. Another reason which may have lowered adherence might be that, despite all efforts, transfer of home monitor data to the online portal was not flawless and several families needed support. In this study, home monitor data had not consequence for treatment. We expect that the adherence will further increase when the monitor data have real impact on disease management and will be used to prevent exacerbations. In this case, children and parents might be more motivated to use the monitor. In the present study, the home monitor was used 3 times a week. It may be that the adherence is better when the home monitor is used on a daily basis as part of the daily routine of patients. The current relative low prices of the home monitors (75 to 200 euro's) increases the chance on a cost-effective eHealth intervention with the monitor, as has been suggested by a recent economic study. ${ }^{6}$

Our findings are in line with a previous study of Sarfaraz et al. in adolescents with CF. ${ }^{4}$ In this study, fifty-one children were included to use a home monitor for six months. Only 19 patients completed recordings that could be evaluated. Nevertheless, Sarfaraz et al found that daily home monitoring contributed to the early detection of PEx, which subsequently may have lowered the need for IV antibiotics. ${ }^{4}$ Lechtzin et al conducted a randomised non-blinded multicentre trial in 320 CF patients (from 14 years) comparing usual care to home monitoring of spirometry and respiratory symptoms using the AM 2+ home monitor twice a week during 1 year. ${ }^{17}$ However, the results of this trial have not been published yet. In asthma, home monitoring is more extensively studied, although only a few studies investigated the effects of home monitoring of the combination of lung function and respiratory symptoms. ${ }^{18}$ In a recent study of our research group in 96 children with asthma, more cases of less well-controlled asthma were detected by prospective home monitoring of $\mathrm{FEV}_{1}$ and symptoms than by a validated questionnaire during hospital visits. ${ }^{7}$ This demonstrates the potential of home monitoring in chronic respiratory diseases in children.

The strengths of our study are: (1) the longitudinal study design with the extended follow-up of 1 year; (2) frequent, thrice-weekly home monitor assessments; (3) home monitor measurements combining lung function and respiratory symptoms and (4) the use of 2 definitions of a PEx, limiting potential misclassification of children.

A limitation may be that although the RSS was based on previous research, ${ }^{19}$ it is not validated and internationally acknowledged yet. Furthermore, the small sample size of our study should be mentioned. External validation of our findings in larger cohort should be performed.

The clinical implication of our study is that electronic home monitoring of symptoms and $\mathrm{FEV}_{1}$ can probably be used for the early detection of PEx. In combination with early antibiotic treatment, it may be possible to prevent (part of) the exacerbations in CF. This 
probably will have a beneficial influence on quality of life, lung function, and perhaps even prognosis. A new study in a larger cohort is necessary to confirm that early detection and improving outcomes are possible. In summary, prevention of PEx is important but in order to prevent PEx we first have to detect these events at an early stage. In the 2 weeks before an exacerbation, the RSS score increased, whereas the combination of home monitor FEV $\mathrm{F}_{1}$ \%pred and RSS in the 4 weeks to 1 week before a PEx could discriminate between children who remained stable and children who developed a PEx. Therefore, home monitoring of symptoms and lung function in children with CF is probably useful to detect PEx at an early stage. 


\section{References}

1. Ferkol T, Rosenfeld M, Milla CE. Cystic fibrosis pulmonary exacerbations. J Pediatr. 2006;148(2):259-64.

2. Bell SC, Robinson PJ. Exacerbations in cystic fibrosis: 2 . prevention. Thorax. 2007;62(8):723-32.

3. Block JK, Vandemheen KL, Tullis E, Fergusson D, Doucette S, Haase D, et al. Predictors of pulmonary exacerbations in patients with cystic fibrosis infected with multi-resistant bacteria. Thorax. 2006;61(11): 969-74.

4. Sarfaraz S, Sund Z, Jarad N. Real-time, once-daily monitoring of symptoms and FEV in cystic fibrosis patients--a feasibility study using a novel device. Clin Respir J. 2010;4(2):74-82.

5. Grzincich G, Gagliardini R, Bossi A, Bella S, Cimino G, Cirilli N, et al. Evaluation of a home telemonitoring service for adult patients with cystic fibrosis: a pilot study. J Telemed Telecare. 2010;16(7):359-62.

6. Tagliente I, Trieste L, Solvoll T, Murgia F, Bella S. Telemonitoring in Cystic Fibrosis: A 4-year Assessment and Simulation for the Next 6 Years. Interact J Med Res. 2016;5(2):e11.

7. van Vliet D, van Horck M, van de Kant K, Vaassen S, Gulikers S, Winkens B, et al. Electronic monitoring of symptoms and lung function to assess asthma control in children. Ann Allergy Asthma Immunol. 2014; 113(3):257-62 e1.

8. Smyth AR, Bell SC, Bojcin S, Bryon M, Duff A, Flume P, et al. European Cystic Fibrosis Society Standards of Care: Best Practice guidelines. J Cyst Fibros. 2014;13 Suppl 1:S23-42.

9. Richter K, Kanniess F, Mark B, Jorres RA, Magnussen H. Assessment of accuracy and applicability of a new electronic peak flow meter and asthma monitor. Eur Respir J. 1998;12(2):457-62.

10. Treggiari MM, Rosenfeld M, Mayer-Hamblett N, Retsch-Bogart G, Gibson RL, Williams J, et al. Early antipseudomonal acquisition in young patients with cystic fibrosis: rationale and design of the EPIC clinical trial and observational study'. Contemp Clin Trials. 2009;30(3):256-68.

11. CBO. Richtlijn diagnostiek en behandeling van cystic fibrosis. 2007.

12. Flume PA, Mogayzel PJ, Jr., Robinson KA, Goss CH, Rosenblatt RL, Kuhn RJ, et al. Cystic fibrosis pulmonary guidelines: treatment of pulmonary exacerbations. Am J Respir Crit Care Med. 2009;180(9):802-8.

13. Akaike H. A new look at the statistical model identification. IEEE Transactions on Automatic Control. 1974;19 (6):716-23.

14. Youden WJ. Index for rating diagnostic tests. Cancer. 1950;3(1):32-5.

15. Goss CH, Burns JL. Exacerbations in cystic fibrosis. 1: Epidemiology and pathogenesis. Thorax. 2007; 62(4):360-7.

16. Burge S, Wedzicha JA. COPD exacerbations: definitions and classifications. Eur Respir J Suppl. 2003;41:46s-53s.

17. Lechtzin N, West N, Allgood S, Wilhelm E, Khan U, Mayer-Hamblett N, et al. Rationale and design of a randomized trial of home electronic symptom and lung function monitoring to detect cystic fibrosis pulmonary exacerbations: the early intervention in cystic fibrosis exacerbation (eICE) trial. Contemp Clin Trials. 2013;36(2):460-9.

18. Jan RL, Wang JY, Huang MC, Tseng SM, Su HJ, Liu LF. An internet-based interactive telemonitoring system for improving childhood asthma outcomes in Taiwan. Telemed J E Health. 2007;13(3):257-68.

19. Goss CH, Edwards TC, Ramsey BW, Aitken ML, Patrick DL. Patient-reported respiratory symptoms in cystic fibrosis. J Cyst Fibros. 2009;8(4):245-52. 


\section{Supplemental table}

Table S6.1 Definition of pulmonary exacerbation according to the Early Pseudomonas Infection Control EPIC trial $^{10}$

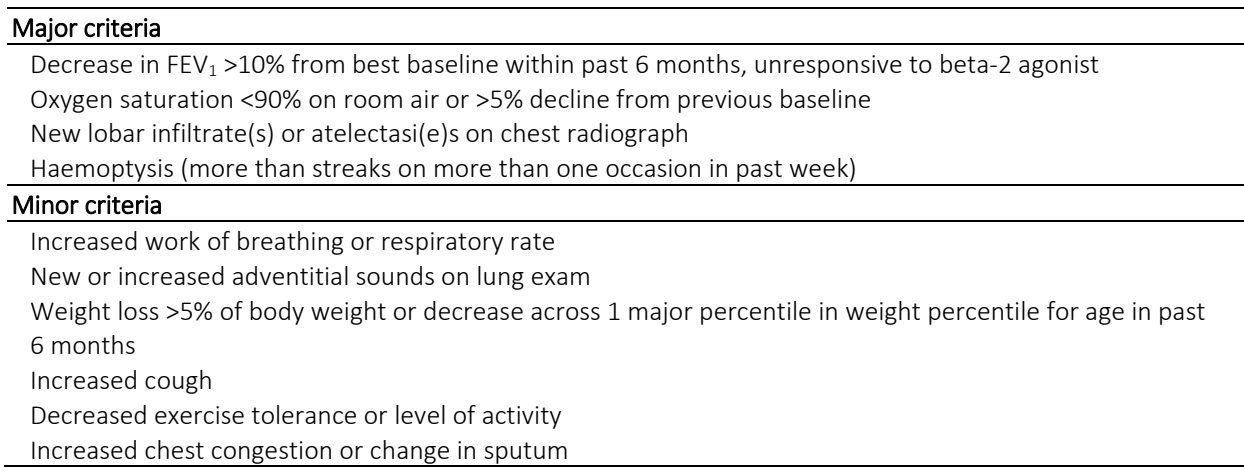





\section{Chapter}

General discussion 



\section{General discussion}

\section{Introduction}

Progressive lung disease is the main determinant of morbidity and mortality of patients with cystic fibrosis (CF). ${ }^{1}$ Lung disease in CF is caused by airway obstruction and inflammation with (chronic) infections, pulmonary exacerbations (PEx), and lung function decline as a consequence. ${ }^{2}$ Slowing down progression of lung disease is a major goal in the management of $\mathrm{CF}^{3}$ which leads to a demanding treatment regimen. Logically, from a patient's perspective, living with CF highly impacts quality of life. Like patients, physicians are increasingly focused on improving health-related quality of life (HRQoL). Furthermore, HRQoL is more often used as an important patient-reported outcome measure in clinical trials. ${ }^{4}$ Lung function, more precisely forced expiratory volume in 1 second $\left(\mathrm{FEV}_{1}\right)$, is associated with HRQoL measures. ${ }^{5,6}$ Moreover, PEx are known to have a substantial impact on $\mathrm{HRQOL}$ in $\mathrm{CF}{ }^{7}$ The occurrence of PEx seems to be an important indicator of lung disease progression in CF, especially in children. ${ }^{8}$ At present, PEx are treated when clinically apparent. As patients frequently wait to seek medical advice, there is often a treatment delay with a more severe course and longer duration of PEx as a consequence. Moreover, this delay increases the risk of permanent lung function loss, airway remodelling, structural lung damage, and destruction of lung parenchyma leading to further lung disease progression. Therefore, it would be very helpful to detect PEx at an early stage (or eventually predict them), in order to adapt treatment, and to improve the prognosis and HRQoL of patients with CF, preferably from birth onwards.

The general purpose of the studies in this thesis was to explore strategies to improve recognition of PEx, to assess factors related to quality of life in children with $\mathrm{CF}$, and to characterise patients with a high exacerbation risk. The specific aims of this thesis were:

- To explore factors that influence change in HRQoL in children with CF, and to evaluate the influence of (the number of) medications on HRQoL;

- To identify risk factors for PEx in children with CF;

- $\quad$ To study the potential of various methods to detect pulmonary CF exacerbations at an early stage like inflammatory markers in exhaled breath condensate (EBC), profiles of exhaled volatile organic compounds (VOCs), and home monitoring of symptoms and lung function.

If early detection is possible, early treatment may prevent (part of the) PEx, reduce the severity of such PEx, and in this way positively impacts patients' overall health status, quality of life, and might slow down progression of lung disease over time. 
In this chapter we will discuss our main findings, compare them to other studies, and speculate about potential clinical implications. The strengths and limitations of our studies are also discussed. Finally, we will provide suggestions for future research.

\section{CF and health-related quality of life (HRQOL)}

Optimising HRQoL is becoming more and more important for patients and their physicians and turns into one of the most important treatment goals. ${ }^{9}$ Most research on HRQoL in children has a cross-sectional character ${ }^{10}$ or only focuses on adolescents or adults in a trial setting. ${ }^{11}$ To our knowledge, our study is the first that longitudinally assessed (changes in) HRQoL in children aged 6 to 18 years with CF, using an observational study design. We hypothesised that pulmonary exacerbations and lung function decline are related to the worsening of cystic fibrosis questionnaire-revised (CFQ-R) respiratory health domains, and that the number of medications/inhalation therapies correlate with higher CFQ-R treatment burden scores.

The results showed that the CFQ-R total score and most domain scores improved significantly during one year of follow-up. This may be a study effect because of the extra visits and attention that patients and their parents received, despite a possible slight increase in treatment burden due to the extra measurements. It has been described previously that participating in a study had a comforting effect on patients, this is also known as a 'trial effect'. ${ }^{12}$

An age older than 12 years was the most important factor that negatively influenced change in HRQoL (CFQ-R total and several domain scores), which may be the consequence of puberty often accompanied by an altered view and perception of disease severity, treatment burden, prognosis, body image, and susceptibility to peer pressure. ${ }^{13,14}$ Moreover, apart from perception of disease, there is an objective increase in disease severity and disease burden during puberty, as reflected by an increased risk of lung function deterioration, ${ }^{15,16}$ higher exacerbation rate, ${ }^{17}$ Pseudomonas aeruginosa colonisation, and number of therapies. ${ }^{18}$ Therefore, the significant influence of age on $\mathrm{HRQOL}$ change is plausible and is in accordance with other longitudinal data on HRQoL in adults and adolescents. In adults, age was a significant predictor of HRQoL in a 12-year study. ${ }^{19}$ A cross-sectional study in children showed significantly lower CFQ-R scores on some domains in adolescents aged $14-18$ years compared to children aged $6-13$ years. ${ }^{20}$ With respect to therapy, we found that the total number of non-inhalation therapies was significantly related to a deterioration of the physical functioning domain of the CFQ-R. As multiple covariates (like $\mathrm{FEV}_{1}$ as percentage of predicted [FEV ${ }_{1} \%$ pred], body mass index, and exacerbation rate) were included in the multivariable analysis, we do not expect that this result has been confounded by disease severity. More likely, this observation implies that an increase in the number of therapies influences HRQoL by 
affecting perception of disease and physical functioning. The question remains how quality of life can be positively influenced, particularly in the age group $>12$ years, and if reduction of the number of therapies can positively influence HRQoL without jeopardising the course of the disease.

PEx were significantly associated with an increased treatment burden score and a trend of borderline significance with the physical functioning domain. A recent Cochrane review also described an inverse relationship between the duration of intravenous therapy for PEx and HRQoL. ${ }^{21}$ This stresses the importance of exacerbations for HRQoL of children with CF, as it seems to affect both treatment burden and physical functioning of patients. Our study demonstrated that it is crucial to gain more insight in HRQoL of children and adolescents, and how HRQoL can be influenced in a positive way. The strategies for early detection of exacerbations described in this thesis may help to improve HRQoL when combined with early treatment and prevention of PEx. Moreover, the expectation is that new treatment with CFTR correctors and potentiators has a positive influence on PEx and quality of life. ${ }^{22}$ Especially during puberty, physicians need to develop approaches to preserve or even improve HRQoL. In the Netherlands, psychological guidance is offered to every patient with CF and a standard consultation is part of the yearly check-up. A possible approach could be to give adolescents tools like an electronic home monitor to make them more aware and in charge of their disease. The challenge for health care workers of the CF teams is to treat and coach this particular group of patients during these turbulent years to optimise lung function, physical and psychosocial functioning, to slow down lung disease progression, and to try to make life as 'normal and easy' as possible.

\section{Progression of lung disease}

The rate and severity of PEx are important for progression of lung disease in CF. ${ }^{8}$ For clinicians it is important to pay attention to factors (like exacerbation rate) which can be influenced in a positive way to slow down lung disease progression. In our study using the Dutch National Patient registry we found that lower $\mathrm{FEV}_{1} \%$ pred value, the use of prophylactic inhaled antibiotics, treatment with proton pump inhibitors (PPI), and PEx in the baseline year were significant risk factors for PEx in the subsequent years. More advanced lung disease with irreversible airway changes leads to a lower lung function level, and to bronchiectasis, mucus impaction/plugging, and fibrosis. Such an environment is prone to microbial colonisation with infections and PEx, ${ }^{23}$ which explains the relationship between $\mathrm{FEV}_{1}$ \%pred and PEx. The finding that PEx in the past are associated with future PEx is not surprising. Comparable to asthma and COPD, there may be a 'frequent exacerbator phenotype' ${ }^{24,25}$ However, the pathogenesis underlying this phenotype is unclear and does not seem to be influenced by environmental factors. ${ }^{26}$ 
A possible explanation can be that these patients have worse mucus clearance because of lower physical activity and/or less application of airway clearance techniques, which can promote bacterial growth, airway infections, and PEx. Another explanation may be that more exacerbations in the past lead to an increased risk on bronchiectasis with an altered (airway) microbiome, increased inflammatory response and higher risk on future PEx as a consequence. We speculate that patients with several subsequent exacerbations do not fully recover, which negatively impacts their overall health status and nutritional status, and their host defence system. An alternative hypothesis is that adherence to treatment in the patients of the 'frequent exacerbator phenotype' is worse with more exacerbations as a consequence.

PPI use turned out to be a risk factor for future PEx. This was an unexpected but important finding, although this study was not designed as a randomised controlled trial (RCT) to compare the (side)effects of PPI with placebo in children with CF. Several explanations for this finding are possible. A poor nutritional status can be the true risk factor because a PPI is often added to the treatment of children with a suboptimal fat absorption despite an adequate dosage of pancreatic enzymes. ${ }^{27}$ Another possible explanation could be an altered airway microbial composition with more pathogenic bacteria as a consequence of a less acid environment in the oesophagus, stomach and perhaps even (upper) airways in case of gastro-oesophageal reflux and (micro)aspiration. Only a properly designed RCT is able to answer the question whether PPI use induces PEx, and to unravel possible mechanisms underlying this relationship.

Finally, inhaled antibiotic use was associated with an increased risk on future PEx. This finding can probably be explained by the use of inhaled antibiotics in patients with Pseudomonas aeruginosa colonisation instead of a harmful effect of inhaled antibiotics themselves. An extra indication for this assumption comes from the statistical analysis: if prophylactic antibiotic use was removed from the statistical model, Pseudomonas colonisation became a significant risk factor for future PEx. Already in children, Pseudomonas infection and colonisation leads to a higher morbidity and mortality. ${ }^{28}$ In our opinion, the yearly check-up which is common practice in CF care, is a good moment to determine the risk profile of a specific patient with respect to risk on future exacerbations and lung disease progression. Furthermore, 'high risk patients' or 'frequent exacerbators' should be identified and monitored more closely already in early childhood and perhaps even from birth onwards, as newborn screening is nowadays implemented in many countries worldwide. ${ }^{29}$ Prevention of lung disease progression should start as early as possible. For this purpose, it is also very important to continue to develop and validate adequate lung function techniques for young children. 


\section{Early detection of exacerbations}

An important step in prevention of lung disease progression is early detection of PEx. Currently, there is no way to objectively diagnose an upcoming PEx. Together with patient delay (and perhaps even doctor delay) this often leads to a postponed start of treatment and maybe even a more severe course of the PEx with permanent lung function loss as a consequence. In three studies of this thesis, we assessed the ability of inflammatory markers in exhaled breath condensate (EBC), volatile organic compounds (VOCs) in exhaled breath, and home monitoring of symptoms and lung function to detect PEx at an early stage.

\section{Inflammatory markers in EBC}

We studied 49 children with CF during a year; every 2 months we collected EBC, inflammatory markers in EBC were measured, and all PEx were recorded. It appeared that early detection of PEx by biomarkers in EBC with the chosen biomarkers and the current method of EBC analysis was not possible in our study. Probably, factors like the overall low concentration and detection of EBC biomarkers contributed to this negative result. To date, there is only one other longitudinal study that investigated the potential of inflammatory markers in EBC to monitor lung disease in children. Horak et al. found that $E B C$ nitrite could not predict pulmonary exacerbations or changes in pulmonary function or clinical and radiological scores. ${ }^{30}$ Because of its non-invasive character, EBC remains an attractive medium for the assessment of inflammatory markers. In order to make better use of this interesting medium, EBC-specific assays should be developed and the potential of other analytical techniques should be explored. Although positive results were reported for nuclear magnetic resonance (NMR) spectroscopy of EBC samples in $\mathrm{CF}$, the clinical application is limited by the expensive, time-consuming, and complicated character of this method. ${ }^{31}$ Improvement of chemical analysis of EBC is necessary before EBC will become of real importance and clinical relevance.

\section{Exhaled VOCS}

In contrast to EBC, exhaled VOCs did show potential to detect PEx in children with CF at an early stage, provided the time between breath sampling and the exacerbation was no longer than 7 days. When this time interval increased, the predictive ability dropped substantially. An explanation for this relative short time period could be that VOC profiles change in response to inflammation induced by (viral) infections, which probably is not a matter of weeks but days before a PEx. No other studies investigated the diagnostic potential of exhaled VOCs to early detect PEx. However, in earlier studies we showed that the concentration of exhaled VOCs changed during the course of a PEx, ${ }^{32}$ 
and that colonisation with Pseudomonas aeruginosa in children with $\mathrm{CF}$ is detectable by VOC profiling with GC-MS. ${ }^{33}$ Moreover, in children with asthma, we demonstrated the potential of exhaled VOCs to predict exacerbations. ${ }^{34}$ Assessment of exhaled VOCs is a promising tool in the monitoring of CF lung disease, and probably an effective way to early detect PEx. The required short time interval between sampling and the onset of PEx implies frequent sampling of exhaled VOCs at one or two occasions a week. Such a sampling frequency is only feasible in clinical practice with sampling at patients' homes. A breath sampler connected to a VOC sensor with rapid analysis and electronic uploading of data to the treating CF centre would be a very interesting approach. If early detection is followed by early antibiotic treatment this may prevent (part of) the exacerbations, which will have a beneficial influence on lung disease progression and HRQoL. The predictive ability for PEx may be further increased by combining assessment of exhaled VOCs with home monitoring of symptoms and lung function.

\section{Home monitoring}

We demonstrated that both $\mathrm{FEV}_{1}$ \%pred value as well as the respiratory symptom score (RSS), assessed by means of an electronic home monitor, were already significantly worse during the four weeks before a PEx in children compared to patients with stable disease (without PEx during the study period of 1 year). Moreover, the RSS further increased in the 2 weeks before a PEx, which may indicate that the RSS is more sensitive for the early detection of PEx than the $\mathrm{FEV}_{1} \%$ pred. A combination threshold of $\mathrm{FEV}_{1} \%$ pred and RSS could detect PEx at an early stage and in this way electronic home monitoring seems a promising tool. Only a few small studies reported about home monitoring in CF. Sarfaraz et al. studied 51 children with CF using an electronic home monitor for 6 months. ${ }^{35}$ Only 19 patients had complete recordings for evaluation. Nevertheless, the conclusion of their study also was that early detection of PEx is possible by using home monitoring. Furthermore, a recent 4-year study of telemonitoring in children with CF demonstrated an improvement in health status with a saving of costs. ${ }^{36}$

The field of E-health is 'under construction' but offers promising possibilities. A substantial part of patients and parents increasingly wants to be 'in charge' of their disease. Home monitoring is a tool to reach this goal especially when combined with other objective measures like exhaled VOCs. A combination of FEV ${ }_{1} \%$ pred, RSS and exhaled VOCs will be able to detect PEx at an early stage.

However, before application, we have to overcome several limitations. First, the adherence to the home monitor has to be improved. Only $70 \%$ of the children used the monitor sufficiently well, which is in accordance with data on the use of the home monitor in children with asthma. ${ }^{37}$ This finding was probably influenced by the technical 
problems with the monitor at the start of our study. When problems like these are solved, this will have a positive influence on adherence to a home monitor. We also expect that the adherence can be positively influenced when the children and parents notice that the results of the home monitor can be used for early detection and prevention of PEx. Another possible limitation of the home monitor use is the risk to further 'medicalise' patients and families and to increase the treatment burden: yet another treatment will be added to the already time-consuming treatment regimen and this might interfere with HRQoL. Moreover, in order to get valid results, it is very important that patients get repeated instructions. Therefore, physicians need to instruct the patients repeatedly and trust their home measurements. It seems conceivable that some patients will embrace and truly benefit home monitoring while others will reject it. In order to optimise electronic home monitoring, a home monitor should be used at least once or twice a week and information should be sent to the CF centre each week in order to ensure continuous monitoring by the CF team. Lung function measurements may be less sensitive in detecting exacerbations than respiratory symptoms. However, a very low $\mathrm{FEV}_{1}$ \%pred or a drop in $\mathrm{FEV}_{1}$ without accompanying symptoms could be a reason to start antibiotic treatment. Coaching of patients using a home monitor should be optimised, especially instructions for lung function measurement and VOC assessment should be repeated and checked frequently. Maybe video communication (i.e. Skype) will have an added value in this matter. Ideally, individual cut-off points would be introduced leading to true personalised medicine.

In conclusion, home monitoring may result in fewer hospital visits, a better insight of patients (and physicians) in their disease, and improved self-management. If early detection leads to prevention of (severe) PEx and hospital admission, it will slow down lung disease progression and eventually will improve prognosis. Furthermore, this might positively influence $\mathrm{HRQOL}$ and will reduce health care costs.

\section{Strengths and limitations}

Our study of early detection of PEx and HRQoL in 49 children with CF (chapter 2, 4, 5 and 6) has several strengths. First, the prospective controlled study design with regular clinical visits every 2 months and standardised measurements of exhaled breath parameters, lung function, sputum cultures, and HRQoL. Furthermore, complete registration of PEx (defined according to 2 different internationally accepted criteria) and of medications during study period is an important point. Last, the multicentre study design ( 3 CF centres in the Netherlands included patients) leads to an increase of the generalizability of the results.

A limitation of our prospective observational study is the relatively small sample size. Besides, the interval of regular clinical visits appeared to be relatively infrequent for the 
prediction of exacerbations with exhaled VOCs. It cannot be ruled out that this interval of 2 months between visits was the reason that inflammatory makers in EBC were not able to detect PEx, although it is more likely that the low concentrations and the lower detection rate of markers was the cause for this result. In an earlier study in children with asthma, measurements of inflammatory markers in EBC every 2 months seemed appropriate, as IL-5 and acidity in EBC were able to predict future PEx. ${ }^{38}$ Another limitation of specifically the home monitor study (chapter 6 ) was that the RSS score of the monitor, although based on previous research, ${ }^{39}$ was not validated. However, the score was sensitive enough to pick up the signal of an upcoming exacerbation.

The study on risk factors for future PEx (chapter 3) made use of the well-defined Dutch national patient registry. This large dataset with multiple measurements during several years allowed us to compare our results with other large international cohorts. A drawback of the Dutch national patient registry is that oral antibiotic courses were not registered in the database. So, we cannot draw conclusions about the results in less severe exacerbations treated with oral antibiotics. Moreover, it appeared that $30 \%$ of the data with respect to intravenous antibiotic courses were missing, which is a limitation too. This drawback was statistically dealt with using the multiple imputation method. Other limitations of the registry might be the relatively small amount of patients not having a F508del mutation, CFRD and/or ABPA.

\section{Conclusions}

Pulmonary exacerbations influence lung disease progression in CF and have an important effect on quality of life of children with CF. It appeared that an age older than 12 years was the strongest independent predictor for a lower HRQoL (both CFQ-R total and several domain scores), whereas the number of PEx was associated with an increase of treatment burden score. Moreover, the total number of (non-inhalation) therapies was associated with worsening of the physical functioning score. The challenge for health care workers of the CF-team is to treat and coach children in this particular age group in order to try to make life as 'normal and easy' as possible, but not losing sight on the goal of slowing down (lung) disease progression.

In our study on risk factors for PEx based on longitudinal data of the Dutch national pPatient registry during several years, we demonstrated that lower $\mathrm{FEV}_{1} \%$ pred value, the use of prophylactic inhaled antibiotics, Pseudomonas aeruginosa colonisation, the use of proton pump inhibitors (PPI), and PEx in the baseline year were significant risk factors for PEx in the subsequent years. In analogy with COPD and asthma, there seems to be a 'frequent exacerbator phenotype' of CF patients, of which the underlying pathogenesis is unclear. The significant association between PPI use and PEx may be caused by an 
altered microbial flora in the airways although confounding by poor nutritional status or disease severity cannot be completely excluded.

With respect to the early detection and prediction of exacerbations we demonstrated that exhaled VOCs, but not inflammatory biomarkers in EBC, were able to detect PEx in children with CF at an early stage, if the time between sampling and exacerbation was not more than 7 days. The methodology for biomarker measurements in EBC should be optimised before EBC will be of clinical relevance. In addition, electronic home monitoring of symptoms and lung function 3 times weekly was able to detect exacerbations at an early stage. However, adherence to a home monitor and reliability of measurements should be further improved. We expect that the use of a home monitor with measurements of symptoms, lung function, and exhaled VOCs can be helpful for the early detection of PEx and to start antibiotic treatment timely. This approach may be of added value for the prevention of PEx. However, new and larger long-term studies are necessary to confirm our findings.

\section{Future research perspectives}

As the experienced well-being of patients is crucial, HRQoL should be a standard outcome measure for future trials and studies. Important questions to be answered on this topic are normal values and clinically meaningful changes in CFQ-R total and subdomain scores. Moreover, it is very relevant to develop new strategies to improve quality of life in children and especially in adolescents with CF.

New and larger cohort studies investigating home monitor use and exhaled breath measurements are necessary in order to know which exhaled VOCs are most predictive for exacerbations, and to assess the influence of viral or specific bacterial infections on the predictive VOCs, and the optimal measurement frequency. For home monitoring the challenge is to be able to adapt alarm settings to individual cut-off points for symptoms and lung function parameters. Moreover, the development of a home monitor, which is able to assess symptoms, lung function, but also exhaled VOCs in CF is relevant. Data of the home monitor should be sent to the responsible CF centre which can analyse the data and look whether specific interventions like an extra clinical evaluation or treatment with antibiotics is necessary. Methods to increase the adherence to the monitor and the reliability of the data are necessary. Eventually, an RCT is needed, in which intervention with such a home monitor in combination with early antibiotic treatment is compared with regular care in order to demonstrate the influence of the intervention on PEx, lung function decline, hospital visits and admissions, quality of life, and medical costs. 
EBC is a fascinating medium for the assessment of biomarkers. However, application and clinical relevance of this non-invasive method are currently hampered by the low detection and low reproducibility of markers. For its use in research and clinical practice, there is a need for the development of specific methods and assays. It is possible that the determination of biomarkers in particles of exhaled breath is a valuable alternative. ${ }^{40}$

Lastly, it is important to study the potential harmful effects of PPI use in a RCT. Important outcome measures in such a trial are PEx, lung function, but also microbiome changes in the airways during treatment with PPI, in order to unravel possible pathogenic mechanisms. 


\section{References}

1. Pittman JE, Ferkol TW. The Evolution of Cystic Fibrosis Care. Chest. 2015;148(2):533-42.

2. Rowe SM, Miller S, Sorscher EJ. Cystic fibrosis. N Engl J Med. 2005;352(19):1992-2001.

3. Smyth AR, Bell SC, Bojcin S, Bryon M, Duff A, Flume P, et al. European Cystic Fibrosis Society Standards of Care: Best Practice guidelines. J Cyst Fibros. 2014;13 Suppl 1:S23-42.

4. Royce FH, Carl JC. Health-related quality of life in cystic fibrosis. Curr Opin Pediatr. 2011;23(5):535-40.

5. Dill EJ, Dawson R, Sellers DE, Robinson WM, Sawicki GS. Longitudinal trends in health-related quality of life in adults with cystic fibrosis. Chest. 2013;144(3):981-9.

6. Sawicki GS, Sellers DE, Robinson WM. Associations between illness perceptions and health-related quality of life in adults with cystic fibrosis. J Psychosom Res. 2011;70(2):161-7.

7. Britto MT, Kotagal UR, Hornung RW, Atherton HD, Tsevat J, Wilmott RW. Impact of recent pulmonary exacerbations on quality of life in patients with cystic fibrosis. Chest. 2002;121(1):64-72.

8. Sanders DB, Goss CH. Pulmonary exacerbations as indicators of progression of lung disease in young children with CF. Thorax. 2013;68(7):608-9.

9. Davies JC, Alton EW. Monitoring respiratory disease severity in cystic fibrosis. Respir Care. 2009;54(5): 606-17.

10. Hegarty M, Macdonald J, Watter P, Wilson C. Quality of life in young people with cystic fibrosis: effects of hospitalization, age and gender, and differences in parent/child perceptions. Child Care Health Dev. 2009;35(4):462-8.

11. Habib AR, Manji J, Wilcox PG, Javer AR, Buxton JA, Quon BS. A systematic review of factors associated with health-related quality of life in adolescents and adults with cystic fibrosis. Ann Am Thorac Soc. 2015; 12(3):420-8.

12. Braunholtz DA, Edwards SJ, Lilford RJ. Are randomized clinical trials good for us (in the short term)? Evidence for a "trial effect". J Clin Epidemiol. 2001;54(3):217-24.

13. Michel G, Bisegger C, Fuhr DC, Abel T, group K. Age and gender differences in health-related quality of life of children and adolescents in Europe: a multilevel analysis. Qual Life Res. 2009;18(9):1147-57.

14. Tibosch MM, Sintnicolaas CJ, Peters JB, Merkus PJ, Yntema JB, Verhaak CM, et al. How about your peers? Cystic fibrosis questionnaire data from healthy children and adolescents. BMC Pediatr. 2011;11:86.

15. Vandenbranden SL, McMullen A, Schechter MS, Pasta DJ, Michaelis RL, Konstan MW, et al. Lung function decline from adolescence to young adulthood in cystic fibrosis. Pediatr Pulmonol. 2012;47(2):135-43.

16. Cogen J, Emerson J, Sanders DB, Ren C, Schechter MS, Gibson RL, et al. Risk factors for lung function decline in a large cohort of young cystic fibrosis patients. Pediatr Pulmonol. 2015.

17. Sutton S, Rosenbluth D, Raghavan D, Zheng J, Jain R. Effects of puberty on cystic fibrosis related pulmonary exacerbations in women versus men. Pediatr Pulmonol. 2014;49(1):28-35.

18. Flume PA, O'Sullivan BP, Robinson KA, Goss CH, Mogayzel PJ, Willey-Courand DB, et al. Cystic fibrosis pulmonary guidelines: chronic medications for maintenance of lung health. Am J Respir Crit Care Med. 2007;176(10):957-69.

19. Abbott J, Morton AM, Hurley MA, Conway SP. Longitudinal impact of demographic and clinical variables on health-related quality of life in cystic fibrosis. BMJ Open. 2015;5(5):e007418.

20. Sawicki GS, Rasouliyan L, McMullen AH, Wagener JS, McColley SA, Pasta DJ, et al. Longitudinal assessment of health-related quality of life in an observational cohort of patients with cystic fibrosis. Pediatr Pulmonol. 2011;46(1):36-44.

21. Plummer A, Wildman M, Gleeson T. Duration of intravenous antibiotic therapy in people with cystic fibrosis. Cochrane Database Syst Rev. 2016;9:CD006682.

22. Wainwright CE, Elborn JS, Ramsey BW. Lumacaftor-Ivacaftor in Patients with Cystic Fibrosis Homozygous for Phe508del CFTR. N Engl J Med. 2015;373(18):1783-4.

23. Elborn JS. Cystic fibrosis. Lancet. 2016.

24. Kupczyk M, ten Brinke A, Sterk PJ, Bel EH, Papi A, Chanez P, et al. Frequent exacerbators--a distinct phenotype of severe asthma. Clin Exp Allergy. 2014;44(2):212-21.

25. Pavord ID, Jones PW, Burgel PR, Rabe KF. Exacerbations of COPD. Int J Chron Obstruct Pulmon Dis. 2016;11 Spec Iss:21-30. 
26. VanDevanter DR, Pasta DJ, Konstan MW. Treatment and demographic factors affecting time to next pulmonary exacerbation in cystic fibrosis. J Cyst Fibros. 2015;14(6):763-9.

27. Ng SM, Jones AP. Drug therapies for reducing gastric acidity in people with cystic fibrosis. Cochrane Database Syst Rev. 2003(2):CD003424.

28. Emerson J, Rosenfeld M, McNamara S, Ramsey B, Gibson RL. Pseudomonas aeruginosa and other predictors of mortality and morbidity in young children with cystic fibrosis. Pediatr Pulmonol. 2002; 34(2):91-100.

29. Dijk FN, McKay K, Barzi F, Gaskin KJ, Fitzgerald DA. Improved survival in cystic fibrosis patients diagnosed by newborn screening compared to a historical cohort from the same centre. Arch Dis Child. 2011;96(12):1118-23.

30. Horak F, Jr., Moeller A, Singer F, Straub D, Holler B, Helbich TH, et al. Longitudinal monitoring of pediatric cystic fibrosis lung disease using nitrite in exhaled breath condensate. Pediatr Pulmonol. 2007; 42(12):1198-206.

31. Montuschi P, Paris D, Melck D, Lucidi V, Ciabattoni G, Raia V, et al. NMR spectroscopy metabolomic profiling of exhaled breath condensate in patients with stable and unstable cystic fibrosis. Thorax. 2012; 67(3):222-8.

32. Berkel van J. There's something in the air: volatile organic compounds in exhaled breath in pulmonary diseases. Maastricht: Maastricht University; 2010.

33. Robroeks CM, van Berkel JJ, Dallinga JW, Jöbsis Q, Zimmermann LJ, Hendriks HJ, et al. Metabolomics of volatile organic compounds in cystic fibrosis patients and controls. Pediatr Res. 2010;68(1):75-80.

34. Robroeks CM, van Berkel JJ, Jöbsis Q, van Schooten FJ, Dallinga JW, Wouters EF, et al. Exhaled volatile organic compounds predict exacerbations of childhood asthma in a 1-year prospective study. Eur Respir J. 2013;42(1):98-106.

35. Sarfaraz S, Sund Z, Jarad N. Real-time, once-daily monitoring of symptoms and FEV in cystic fibrosis patients--a feasibility study using a novel device. Clin Respir J. 2010;4(2):74-82.

36. Tagliente I, Trieste L, Solvoll T, Murgia F, Bella S. Telemonitoring in Cystic Fibrosis: A 4-year Assessment and Simulation for the Next 6 Years. Interact J Med Res. 2016;5(2):e11.

37. van Vliet D, van Horck M, van de Kant K, Vaassen S, Gulikers S, Winkens B, et al. Electronic monitoring of symptoms and lung function to assess asthma control in children. Ann Allergy Asthma Immunol. 2014;113(3):257-62 e1.

38. Robroeks CM, van Vliet D, Jobsis Q, Braekers R, Rijkers GT, Wodzig WK, et al. Prediction of asthma exacerbations in children: results of a one-year prospective study. Clin Exp Allergy. 2012;42(5):792-8.

39. Goss CH, Edwards TC, Ramsey BW, Aitken ML, Patrick DL. Patient-reported respiratory symptoms in cystic fibrosis. J Cyst Fibros. 2009;8(4):245-52.

40. Tinglev $\AA$, Ullah S, Ljungkvist G, Viklund E, Olin AC, Beck O. Characterization of exhaled breath particles collected by an electret filter technique. J Breath Res. 2016;10(2):026001. 

Summary 



\section{Summary}

Cystic fibrosis (CF) is an inborn, chronic, multi-system disease with a shortened life expectancy. The prognosis of patients with CF is influenced by mutation class (genotype) but also by nutritional status, lung disease progression and adherence to intensive treatments. CF lung disease is characterised by chronic airway inflammation in combination with pulmonary exacerbations (PEx) leading to irreversible airway changes eventually progressing to respiratory failure. The frequency and severity of these PEx mainly determine lung disease progression. Moreover, PEx influence health-related quality of life (HRQoL). Currently, PEx cannot be predicted or detected at an early stage. Treatment starts when an exacerbation is diagnosed. We hypothesise that early detection of PEx combined with early antibiotic treatment will prevent part of the PEx, or reduce severity of PEx and in this way improve long term prognosis and HRQoL. In this thesis, characteristics of patients with a high exacerbation rate were investigated and novel strategies for early recognition of PEx were explored. Furthermore, factors related to HRQoL in children with CF were assessed.

Quality of life is important for patients with CF, and improvement of HRQoL is an important treatment goal for physicians. In CF, HRQoL can be measured by the validated disease specific cystic fibrosis questionnaire-revised (CFQ-R). Although CF is a chronic disorder, longitudinal data on HRQoL in children with CF are scarce. Prior cross-sectional studies in children demonstrated that age, gender, body mass index (BMI), PEx, and lung function do influence HRQoL. In Chapter 2, longitudinal associations between several (clinical and treatment) variables and changes in CFQ-R scores were investigated. During 1 year of follow-up, the CFQ-R total score as well as most domain scores (all range from 0 to 100 with higher scores corresponding to higher quality of life) improved significantly. An older age, especially above 12 years, was associated with a deterioration of CFQ-R total score; per year increase in age the CFQ-R total score decreased with 2.9 points. Puberty might play an important role in this finding, whereas also others found lower scores in this age group. Moreover, the number of PEx was associated with an increase in treatment burden score, and the total number of (non-inhalation) therapies was correlated with a decrease of the physical functioning score. Development of strategies to optimise HRQoL is especially important for adolescents.

Exacerbation rate is an important determinant for lung disease progression in CF. Identification of frequent exacerbators would allow physicians to intensify monitoring or to adjust treatment in order to slow down lung disease progression in this group. Chapter 3 focuses on potential risk factors for future PEx. 545 children aged above 5 years and registered in the Dutch CF registry from 2009 to 2014 were included. 
Significant risk factors for PEx in the subsequent years were a lower forced expiratory volume in 1 second $\left(\mathrm{FEV}_{1}\right)$ as percentage of predicted ( $\left.\mathrm{FEV}_{1} \% \mathrm{pred}\right)$, presence of PEx, the use of prophylactic inhaled antibiotics, and the use of proton pump inhibitors (PPI) in the baseline year. A lower $\mathrm{FEV}_{1}$ \%pred and PEx in the past are known risk factors for future PEx. The association between the use of prophylactic inhaled antibiotics and future PEx can probably be explained by the colonisation with Pseudomonas aeruginosa in these patients. It happened, Pseudomonas colonisation became a significant risk factor when the use of prophylactic antibiotics (including macrolides) was removed from the model. There are several possible explanations for the potential risk of PPI use, which requires further research. It may be that the relationship between PPI and future PEx is confounded by disease severity and poor nutritional status. Another possible explanation could be an altered gastric and/or airway bacterial colonisation with more pathogenic bacteria leading to an increased risk for respiratory tract infections and PEx.

Although CF is characterised by chronic airway inflammation, therapy is not based on (direct) measures of the underlying airway inflammation, but on symptoms and lung function. The inflammatory response also plays an important role during PEx. Markers of airway inflammation may be useful to early detect or predict PEx. In chapters 4 and 5 , early detection of PEx by exhaled inflammatory markers was studied in 49 children with CF during 1 year. Exhaled breath condensate (EBC) is a safe, fast and non-invasive technique, which is also feasible in young children. Inflammation markers interleukin (IL)-6, IL-8, tumor necrosis factor $\alpha$ (TNF- $\alpha$ ), and macrophage migration inhibitory factor (MIF) were measured using high sensitivity bead based flow immunoassays every two months during 1 year. Chapter 4 demonstrated that the diagnostic accuracy of these inflammatory markers and acidity of EBC was low. The area under de receiver operating characteristic curve for prediction of PEx was 0.62. The chosen EBC markers and methods were not able to early detect PEx in children with CF.

In chapter 5 we assessed the potential of another technique to analyse inflammation markers in exhaled breath; analysis of exhaled volatile organic compounds (VOCs). It was shown that PEx could be early detected by VOCs in exhaled breath of children with CF if time between sampling and the onset of an exacerbation was no longer than 7 days. The random forrest model with the 9 most discriminatory VOCs was able to correctly predict $79 \%$ of cases (sensitivity $79 \%$ and specificity $78 \%$ ). VOCs were measured by gas chromatography-time-of-flight-mass spectrometry. To our knowledge this is the first study demonstrating that PEx in CF can be early detected by VOCs. A future approach could be frequent sampling of exhaled breath at home by means of an eNose system able to detect VOCs relevant for exacerbations of CF lung disease. 
In chapter 6 electronic home monitoring of respiratory symptoms and lung function of children with CF was investigated. As PEx cannot be predicted reliably yet, there is a need for other ways to early detect changes in the clinical situation to start therapy timely. 49 children were requested to use a home monitor 3 times a week during a year. The $\mathrm{FEV}_{1} \%$ pred and respiratory symptom score (RSS) were assessed. There was a significant mean difference of $16.3 \%$ in $\mathrm{FEV}_{1} \%$ pred between the exacerbation group and the no exacerbation group at the start of a PEx. This implies that a lower FEV $\mathrm{F}_{1} \%$ pred may indeed be a risk factor for exacerbations. In the two weeks before a PEx the RSS increased in the exacerbation group, and was significantly worse in the exacerbation group compared to the no exacerbation group at the start of a PEx (mean difference 3.0 points on a scale of 0 to 9). Furthermore it was shown that the combination of $\mathrm{FEV}_{1} \%$ pred and RSS of 4 to 1 week before a PEx had a sensitivity of 92\% and specificity of $89 \%$ to predict an exacerbation in this group of children. This emphasised that electronic home monitoring of respiratory symptoms and $\mathrm{FEV}_{1} \%$ pred has added value in early detection of PEx in children with CF.

In summary, the main findings described in this thesis illustrate that PEx are important events in CF lung disease progression. Amongst other factors, PEx influence HRQoL, and especially during puberty and adolescence HRQoL needs attention to prevent further deterioration. Furthermore, already at a young age past PEx are associated with future $P E x$, therefore also in children with CF frequent exacerbators seem to exist. Other risk factors for future PEx are a lower FEV $\mathrm{F}_{1} \%$ pred, the use of inhaled prophylactic antibiotics, and unexpectedly the use of PPI which requires further investigation. Finally, some of the explored strategies to recognise PEx, such as VOCs in exhaled breath and electronic home monitoring, can be helpful to detect PEx in children with CF at an early stage. The true value of these findings will be determined by future research. Early detection or prediction of PEx combined with early antibiotic treatment may prevent part of the PEx, or reduce severity of such PEx and eventually improve the prognosis of children with CF and positively impact HRQoL. 

Samenvatting 



\section{Nederlandse samenvatting}

Taaislijmziekte, ofwel cystic fibrosis (CF) is een erfelijke en chronische ziekte waarbij meerdere orgaansystemen, waaronder de longen en de alvleesklier kunnen worden aangetast. Mensen met CF hebben een beperkte levensverwachting. De prognose wordt beïnvloed door het type genmutatie wat aan de ziekte ten grondslag ligt maar ook door onder andere voedingsstatus, mate van progressie van de longziekte en therapietrouw. De longziekte bij CF wordt gekenmerkt door een chronische ontsteking van de luchtwegen in combinatie met acute verslechteringen, ook wel pulmonale exacerbaties genoemd. Dit alles leidt tot blijvende veranderingen van de luchtwegen die uiteindelijk kunnen leiden tot chronische longschade en longfalen. De frequentie en ernst van deze exacerbaties bepalen hoofdzakelijk de progressie van de longziekte. Daarnaast hebben exacerbaties impact op de kwaliteit van leven van patiënten met CF.

Op dit moment kunnen exacerbaties niet voorspeld of vroeg herkend worden. Hierdoor wordt de antibiotische behandeling pas gestart als een exacerbatie is vastgesteld. Onze hypothese is dat vroege herkenning van exacerbaties in combinatie met vroege antibiotische behandeling een deel van de exacerbaties kan voorkómen en/of de ernst kan doen verminderen. Dit kan een positieve invloed hebben op de prognose en de kwaliteit van leven van kinderen en volwassenen met CF.

In dit proefschrift werden risicofactoren voor toekomstige exacerbaties onderzocht en werden nieuwe strategieën om exacerbaties vroeg te herkennen getest. Daarnaast werd gekeken naar factoren die gerelateerd zijn aan een verbetering/verslechtering van de kwaliteit van leven van kinderen met CF.

Voor patiënten met CF staat een zo goed mogelijke kwaliteit van leven voorop en verbetering van deze kwaliteit van leven is daarom een belangrijk behandeldoel voor artsen, zeker bij kinderen. De cystic fibrosis questionnaire-revised (CFQ-R) is een gevalideerde vragenlijst welke specifiek gericht is op patiënten met CF. Ondanks dat CF een chronische ziekte is, zijn lange termijn gegevens over kwaliteit van leven van kinderen met CF nauwelijks voorhanden. Eerdere dwarsdoorsnede onderzoeken bij kinderen hebben aangetoond dat leeftijd, geslacht, body mass index (BMI), exacerbaties en longfunctie van invloed zijn op de kwaliteit van leven. In hoofdstuk 2 werden lange termijn associaties tussen verschillende variabelen (zowel klinische kenmerken als verschillende therapieën) en veranderingen van de CFQ-R scores onderzocht. Gedurende een jaar follow-up verbeterden zowel de totale CFQ-R score als de meeste domein scores significant (de scores kunnen variëren tussen 0 en 100 , een hogere score komt overeen met een betere kwaliteit van leven). Een leeftijd boven de 12 jaar was geassocieerd met een verslechtering van de totale CFQ-R score; voor elk jaar extra nam 
de CFQ-R totale score af met 2.9 punten wat significant was vanaf een leeftijd van 15 jaar. Het kan goed zijn dat de puberteit hier een belangrijke rol in speelt want ook andere studies vonden lagere scores in deze leeftijdscategorie. Uit deze resultaten blijkt dat de ontwikkeling van strategieën om kwaliteit van leven te optimaliseren vooral gericht moet zijn op pubers en adolescenten. Daarnaast was het aantal exacerbaties geassocieerd met een toename van de score met betrekking tot de 'ervaren last van behandeling' wat opnieuw de impact van exacerbaties laat zien.

De frequentie en de ernst van exacerbaties zijn belangrijke factoren voor de progressie van de longziekte bij kinderen en volwassenen met CF. Het zou artsen helpen om patiënten te kunnen identificeren die frequent exacerbaties hebben om op die manier deze patiënten beter te kunnen monitoren en/of de behandeling eerder te kunnen aanpassen zodat progressie van de CF longziekte vertraagd wordt. Hoofdstuk 3 richt zich op mogelijke risicofactoren voor toekomstige exacerbaties. Voor dit onderzoek werden 545 kinderen met CF geïncludeerd die geregistreerd waren in de Nederlandse CFregistratie tussen 2009 en 2014 en die ouder waren dan 5 jaar. Significante risicofactoren voor exacerbaties in de daarop volgende jaren waren een lagere één seconde waarde $\left(\mathrm{FEV}_{1}\right.$ ) als percentage van de voorspelde waarde ( $\mathrm{FEV}_{1} \% \mathrm{pred}$ ), het hebben van eerdere exacerbaties, het profylactisch gebruik van antibiotica (inclusief macroliden) en het gebruik van protonpompremmers gedurende het eerste jaar dat een kind geregistreerd was. Een lagere $\mathrm{FEV}_{1} \%$ pred en exacerbaties in het verleden zijn bekende risicofactoren voor toekomstige exacerbaties. De associatie tussen het profylactisch gebruik van antibiotica en toekomstige exacerbaties kan waarschijnlijk verklaard worden doordat deze patiënten gekoloniseerd zijn met Pseudomonas aeruginosa en daardoor deze antibiotica krijgen. Het bleek inderdaad zo te zijn dat kolonisatie met Pseudomonas een significante risicofactor werd als het profylactisch gebruik van antibiotica werd weggelaten uit het model. Er zijn verschillende mogelijke verklaringen voor het potentiële risico van het gebruik van protonpompremmers. Het kan zijn dat de indicatie (refluxziekte of een verminderde voedingstoestand) voor het gebruik van deze medicatie de echte risicofactor is of wellicht geven protonpompremmers een verandering van het microbioom van het maagdarmstelsel en/of de luchtwegen waardoor er eerder infecties en exacerbaties ontstaan. Het mogelijke risico van protonpompremmers is een belangrijk onderwerp voor verder onderzoek.

Ondanks dat CF gekenmerkt wordt door een chronische ontsteking van de luchtwegen, wordt de behandeling momenteel niet aangepast op basis van de mate van die onderliggende luchtwegontsteking, maar op basis van symptomen en longfunctiewaarden. De ontstekingsreactie speelt echter wel een belangrijke rol tijdens exacerbaties. Daarom zouden ontstekingsmarkers uit de luchtwegen waardevol kunnen 
zijn voor de vroege herkenning of zelfs voorspelling van exacerbaties. In hoofdstuk 4 en 5 werd de vroege herkenning van exacerbaties door middel van ontstekingsmarkers uit de luchtwegen onderzocht bij 49 kinderen met CF. Condensaat van uitgeademde lucht (ofwel exhaled breath condensate, EBC) is een veilige, snelle en niet invasieve techniek om ontstekingsmarkers vanuit de luchtwegen te meten. Deze techniek is ook prima toepasbaar bij jonge kinderen. Gedurende een jaar werden elke 2 maanden de ontstekingsmarkers interleukine 6 (IL-6), interleukine 8 (IL-8), tumor necrosis factor $\alpha$ (TNF- $\alpha$ ) en macrophage migration inhibitory factor (MIF) in EBC gemeten. De resultaten van hoofdstuk 4 laten zien dat de voorspellende waarde van deze ontstekingsmarkers en de zuurgraad van het EBC voor CF exacerbaties laag was. De oppervlakte onder de reciever operating characteristic (ROC) curve van de grafiek die staat voor de kwaliteit van de voorspelling van exacerbaties was slechts 62\%. Op dit moment zijn de geselecteerde ontstekingsmarkers in EBC met de gekozen analysetechniek niet in staat om exacerbaties bij kinderen met CF vroeg te herkennen.

In hoofdstuk 5 bespreken we een andere methode om ontsteking in de luchtwegen te meten namelijk vluchtige organische componenten (ofwel volatile organic compounds, VOCs) in uitademingslucht. VOCs werden elke 2 maanden gedurende een jaar gemeten door middel van gas chromatografie 'time-of-flight' massa spectrometrie. Exacerbaties bij kinderen met CF kunnen vroeg gedetecteerd worden door middel van VOCs in uitademingslucht als de tijd tussen het analyseren en de start van een exacerbatie niet langer is dan 7 dagen. Het model met de 9 meest voorspellende VOCs was in staat om 79\% van de exacerbaties goed te voorspellen (sensitiviteit $79 \%$ en specificiteit $78 \%$ ). Voor zover bij ons bekend is dit de eerste studie die laat zien dat CF exacerbaties vroeg herkend kunnen worden door middel van VOCs in uitademingslucht. Een toekomstige stap kan zijn om thuis frequenter uitademingslucht te meten door middel van een elektronische neus die in staat is om VOCs die relevant zijn voor CF exacerbaties te meten.

De potentie van elektronische thuismonitoring van luchtwegklachten en longfunctie bij kinderen met CF werd onderzocht in hoofdstuk 6. Omdat exacerbaties nog niet betrouwbaar voorspeld kunnen worden is er een noodzaak om op nieuwe manieren veranderingen in de klinische situatie vroeg te herkennen en behandeling op tijd te kunnen starten. Aan 49 kinderen werd gevraagd om 3 keer per week een elektronische thuismonitor te gebruiken gedurende een jaar. Met de thuismonitor werd een score voor luchtwegklachten (de respiratoire symptoom score of RSS) en de FEV ${ }_{1} \%$ pred gemeten. In de 4 weken voor en bij de start van een exacerbatie was er een significant verschil van $16.3 \%$ in gemiddelde $\mathrm{FEV}_{1} \%$ pred tussen de groep kinderen met exacerbaties en de groep zonder exacerbaties. Dit toont aan dat een lagere $\mathrm{FEV}_{1} \%$ pred inderdaad een 
risicofactor voor exacerbaties lijkt te zijn en dat de $\mathrm{FEV}_{1} \%$ pred al langer voor een exacerbatie verslechterd is. Gedurende de 2 weken voor een exacerbatie steeg de symptoomscore in de exacerbatiegroep en verschilde deze significant met de groep zonder exacerbaties (een gemiddeld verschil van 3.0 punten op een schaal van 0 tot 9). Daarnaast bleek dat de combinatie van $\mathrm{FEV}_{1} \%$ pred en de RSS 1 tot 4 weken voor een exacerbatie exacerbaties kon voorspellen met een sensitiviteit van $92 \%$ en specificiteit van $89 \%$. Dit benadrukt dat elektronische thuismonitoring van luchtwegklachten en longfunctie van toegevoegde waarde kan zijn bij het vroeg herkennen van exacerbaties bij kinderen met CF.

Samenvattend tonen de voornaamste bevindingen van dit proefschrift aan dat exacerbaties belangrijk zijn en invloed hebben op de progressie van CF longziekte en daarom voorkomen moeten worden. Exacerbaties hebben, naast andere factoren, invloed op de kwaliteit van leven en specifiek tijdens de puberteit en adolescentie moet er aandacht zijn om verslechtering van kwaliteit van leven te voorkomen. Op de kinderleeftijd zijn exacerbaties in het verleden geassocieerd met exacerbaties in de toekomst wat zou kunnen wijzen op een 'frequent exacerbatie fenotype' bij kinderen met CF. Een dergelijk fenotype werd al eerder beschreven bij patiënten met astma en met COPD. Andere risicofactoren voor exacerbaties zijn een lagere $\mathrm{FEV}_{1} \%$ pred, het profylactisch gebruik van antibiotica (waarschijnlijk als indicator voor kolonisatie met Pseudomonas aeruginosa) en ook het gebruik van protonpompremmers. Er is meer onderzoek nodig naar eventuele risico's van het gebruik van protonpompremmers bij kinderen met CF. Het analyseren van VOCs in uitademingslucht en elektronische thuismonitoring van luchtwegklachten en longfunctie kunnen waardevolle technieken zijn om exacerbaties bij kinderen met CF in een vroeg stadium te herkennen. De waarde van deze bevindingen zal moeten worden onderzocht in toekomstige studies. Vroege herkenning van exacerbaties gecombineerd met vroege antibiotische behandeling zou een deel van de exacerbaties kunnen voorkomen of de ernst ervan doen verminderen. Dit alles met als uiteindelijk doel de prognose van kinderen (en volwassenen) met CF te verbeteren en hun kwaliteit van leven te verbeteren. 

Valorisation 


\section{Valorisation}

The knowledge derived from this thesis can be of societal and economical value in different ways. The valorisation of the acquired knowledge about risk factors for pulmonary exacerbations (PEx), strategies to early detect PEx, and factors influencing health-related quality of life (HRQOL) in children with cystic fibrosis (CF) is presented in this chapter.

CF is the most common life-shortening genetic disease in the Caucasian population, ${ }^{1}$ with an incidence in the European Union of 1 in 2000-3000 newborns, and approximately 1500 people with CF living in the Netherlands. ${ }^{2}$ Newborn screening has led to earlier diagnosis and therapy and consequently to improved survival. ${ }^{3}$ Recently, gene-modifying drugs that target the underlying genetic defect have been developed and resulted in clinical improvement. ${ }^{4}$ Life expectancy improved to $40-50$ years for a child born with CF today. ${ }^{5}$ However, despite these advances, CF is one of the most challenging diseases to manage and is still life-shortening. The treatment regimen is intensive and takes on average $2-4$ hours per day. ${ }^{6}$ Moreover, research has shown that a large proportion of individuals with CF and their parents have symptoms of depression and anxiety. ${ }^{7}$ In these ways, CF highly impacts the lives of children and their families.

Prediction of PEx in combination with early treatment may lead to less (severe) PEx, more stable disease, and eventually to an improved overall health status and a better prognosis. More stable CF in children with less (severe) PEx will have a favourable influence on quality of life and work absenteeism of their parents. Ultimately, prevention of PEx may induce fewer hospital admissions, fewer prescriptions of (chronic) medication, and perhaps even fewer lung transplants and a better survival. In this way also health costs will be lower, which is economically relevant in order to have an affordable and sustainable health care system for our society.

Electronic home monitoring of symptoms and lung function may be a step forward in prediction of PEx, especially if combined with exhaled volatile organic compounds (VOCs) measurements in the future.

The non-invasive assessment of exhaled VOCs is innovative and very promising, not only in children with CF but also in asthma and other pulmonary diseases. ${ }^{8,9}$ In addition, VOCs can also give information about inflammation processes in other organs. ${ }^{10}$ One of the next steps is to further determine which VOCs are most discriminatory for PEx in CF in a 
large cohort. Thereafter, an RCT should be performed to assess the impact of early treatment based on prediction of PEx by VOCs on lung disease progression and HRQoL.

Several patients and parents experienced direct benefit from electronic home monitoring of lung function and symptoms: they felt supported by the availability of a home monitor, and were better able to objectify their feelings about their (child's) health status. Some children even used it on a daily basis. A home monitor gives direct objective information and therefore may enforce the self-supportiveness of these families. In this way electronic home monitoring may also positively influence HRQoL.

By means of the home monitor, the CF team was able to identify changes in respiratory symptoms or lung function on a weekly basis instead of only at check-ups every 3 months. In daily practice, home monitor data can be used by the physician in several ways, for example to discuss symptom recognition and necessary changes in management strategies.

It is possible that an eHealth approach with use of the home monitor is able to partly reduce the frequency of visits to the hospital, which in turn may have a beneficial influence on HRQoL. Next steps are to investigate electronic home monitoring in a larger (international) cohort. Further research is necessary to increase the reliability of and the adherence to the home monitor, and to assess in a larger randomised controlled trial (RCT) whether intervention based on home monitor data is indeed able to reduce PEx. If this further research supports our findings, home monitoring might be included in (inter)national CF guidelines.

The combination of electronic home monitoring with measurement of exhaled VOCs to further complete information on the patients' clinical status would be even more innovative. For this purpose industrial companies will be involved because a new, comprehensive, handheld device should be developed. Besides, the transfer of home monitor information to the CF team can be improved, an application for mobile devices is one of the future steps to make, involving information technology companies. Another step could be to incorporate even more functions in this new device, such as a serious game for children to improve mucus clearance or a tool for medication checks.

Shared decision making is an important topic in medicine. For this purpose decision aids are being developed. In advanced CF, when patients are considering lung transplant, a decision tool increased knowledge and realistic expectations while decreasing decisional conflict. ${ }^{11}$ This thesis showed that an older age (above 12 years) and PEx are important 
factors that negatively influence HRQoL. With this knowledge it is important to especially engage adolescents with CF to discuss possible 'obstacles' in daily life with their CF team. In this way compliance may be improved and changes in treatment may have less effect on HRQoL. Future steps could be to develop and test decision tools directed specifically at adolescents. For the implementation of such decision tools, national and international CF foundations should be involved.

Finally, this thesis showed that the use of PPI may be a risk factor for future PEx. It is not clear whether GERD or PPI use itself is the actual risk factor. One of the hypotheses why the use of PPI may lead to PEx is that the bacterial colonisation of the airways may alter as a consequence of a less acid environment of the stomach and oesophagus. The safety and possible adverse effects of PPI use in CF should be investigated in an RCT. Assessment of GERD and the airway microbiome should be part of such a trial. 


\section{References}

1. O'Sullivan BP, Freedman SD. Cystic fibrosis. Lancet. 2009;373(9678):1891-904.

2. Foundation DCF. Dutch Cystic Fibrosis Registry, Report 2014. 2014.

3. Dijk FN, McKay K, Barzi F, Gaskin KJ, Fitzgerald DA. Improved survival in cystic fibrosis patients diagnosed by newborn screening compared to a historical cohort from the same centre. Arch Dis Child. 2011;96(12):1118-23.

4. Wainwright CE, Elborn JS, Ramsey BW. Lumacaftor-Ivacaftor in Patients with Cystic Fibrosis Homozygous for Phe508del CFTR. N Engl J Med. 2015;373(18):1783-4.

5. Dodge JA, Lewis PA, Stanton M, Wilsher J. Cystic fibrosis mortality and survival in the UK: 1947-2003. Eur Respir J. 2007;29(3):522-6.

6. Sawicki GS, Ren CL, Konstan MW, Millar SJ, Pasta DJ, Quittner AL, et al. Treatment complexity in cystic fibrosis: trends over time and associations with site-specific outcomes. J Cyst Fibros. 2013;12(5):461-7.

7. Smith BA, Georgiopoulos AM, Quittner AL. Maintaining mental health and function for the long run in cystic fibrosis. Pediatr Pulmonol. 2016;51(S44):S71-S8.

8. van de Kant KD, van der Sande LJ, Jöbsis Q, van Schayck OC, Dompeling E. Clinical use of exhaled volatile organic compounds in pulmonary diseases: a systematic review. Respir Res. 2012;13:117.

9. Fens N, van der Schee MP, Brinkman P, Sterk PJ. Exhaled breath analysis by electronic nose in airways disease. Established issues and key questions. Clin Exp Allergy. 2013;43(7):705-15.

10. Miekisch W, Schubert JK, Noeldge-Schomburg GF. Diagnostic potential of breath analysis--focus on volatile organic compounds. Clin Chim Acta. 2004;347(1-2):25-39.

11. Vandemheen KL, O'Connor A, Bell SC, Freitag A, Bye P, Jeanneret A, et al. Randomized trial of a decision aid for patients with cystic fibrosis considering lung transplantation. Am J Respir Crit Care Med. 2009;180(8):761-8. 
v 

Dankwoord 



\section{Dankwoord}

Het laatste hoofdstuk van mijn boekje, de klus is geklaard, ik heb het eindstation bereikt! Maar niet zonder een heleboel anderen, promoveren doe je niet alleen! Mijn promotietraject was als een trein die door de bergen reed, soms bergop, zwaar puffend maar dan toch een piek bereikend. Soms bergaf, schijnbaar zonder moeite en goed in balans. Ook waren er enkele dalen, maar gelukkig reisden er vanaf het begin hele fijne mensen met me mee.

Allereerst wil ik natuurlijk alle kinderen en hun ouders die mee hebben gedaan aan mijn studie van harte bedanken, zonder jullie was mijn onderzoek niet mogelijk geweest! Ik waardeer het heel erg dat jullie naast al jullie behandelingen, tijd hebben gemaakt om de thuismonitor te gebruiken en elke twee maanden naar het ziekenhuis te komen. Ik hoop echt dat we met dit onderzoek een steentje bij kunnen dragen aan een betere prognose en kwaliteit van leven voor kinderen én volwassenen met cystic fibrosis! Dat achter de wolken hopelijk de zon wat meer schijnt.

Grote dank gaat uit naar mijn promotieteam!

Beste Edward, in eerste instantie klopte ik bij je aan met een ander onderzoeksplan. Je ondersteunde mijn ideeën, zette me aan het denken waar nodig en maakte me nog meer enthousiast voor de wetenschap. Niet lang daarna kwam de vraag of ik niet na wilde denken om te gaan promoveren op dit onderzoek. Vanaf toen was je mijn promotor en de drijvende kracht achter ons project. Je onbegrensde optimisme en bijna onuitputtelijke bron met nieuwe onderzoeksplannen bewonder ik zeer. Ook als mens hebben we elkaar steeds beter leren kennen en heb ik veel waardering voor je.

Beste Geertjan, jij stapte gedurende de rit op mijn promotietrein, op een moment dat de trein even leek stil te blijven staan. Toen het nodig was hakte je knopen door en stond je achter mij en ons onderzoek. Dank voor je constructieve blik en bemoedigende woorden.

Beste Bjorn, ook jij kwam wat later aan boord. Heel eerlijk dacht ik in het begin, hoe zal dat lopen met een statisticus in mijn promotieteam... maar ik heb nog nooit zo'n aardige, geduldige en 'menselijke' statisticus ontmoet. Je bijdrage was van onschatbare waarde! Dank voor je geduld en je harde werken (ook als er weer iets niet bleek te kloppen in een database of een analyse opnieuw moest worden gedaan), je uitleg en je oprechte persoonlijke interesse. 
Beste Rijn, uiteindelijk niet in de 'officiële' rol van co-promotor maar zo voelt het zeker wel! Vanaf dag 1 ben je betrokken bij zowel mijn promotietraject als bij mijn opleiding tot kinderarts in de rol van mentor. Jij zorgt er voor dat we als onderzoeksteam met beide benen op de grond blijven staan, je bent kritisch, realistisch en eerlijk. Ik waardeer de gesprekken die we hebben gehad en vond het ook heerlijk om met jou als 'reisleider' door Amsterdam, Londen en Sevilla te lopen!

Beste Kim, ook jij bent geen officieel lid van mijn promotieteam maar zonder jou was het me niet gelukt! Ik vond het erg prettig dat ik altijd met kleine en grote vragen bij je terecht kon. Jouw hulp, ervaring en feedback waren altijd erg waardevol. Daarnaast is het fijn om eens met iemand te sparren die in dezelfde levensfase zit, en heerlijk om samen met en van onze jongens te genieten!

De leden van de beoordelingscommissie, prof. dr. Luc Zimmermann, prof. dr. Boris Kramer, prof. dr. Paul Savelkoul, prof. dr. Chris de Boeck en dr. Harry Heijerman wil ik bedanken voor het lezen en beoordelen van mijn proefschrift. Beste Luc, sinds de start van mijn opleiding heb ik in verschillende rollen met je te maken gehad. Als opleider, hoofd van de afdeling maar gedurende mijn onderzoek ook als plaatsvervangend begeleider en uiteindelijk als hoofd van de leescommissie. Toen het nodig was kon ik op je bouwen, dank daarvoor.

De NCFS wil ik bedanken voor hun (financiële) steun voor dit onderzoek. Vincent Gulmans, bedankt als co-auteur en vraagbaak rondom de registratie. Chiesi Pharmaceuticals dank voor de onderzoekssubsidie.

Voor mijn onderzoek werkte ik samen met de afdelingen kinderlongziekten van het WKZ in Utrecht en het AMC in Amsterdam. Karin, Kors, Ilja en Wim, dank voor jullie inzet en positieve woorden, jullie zorgden er vaak voor dat ik de moed er in hield en me gewaardeerd voelde. Sylvia, in Maastricht als research nurse een belangrijke spil in het onderzoek. Dank voor je inzet en voor de gezelligheid. Sabine, Eltje en Margreet, in Utrecht kon ik op jullie hulp rekenen. En Nora, in Amsterdam was jij de stabiele factor.

Ook de longfunctieafdelingen van alle drie ziekenhuizen wil ik niet vergeten. In Maastricht wil ik speciaal Chris van der Grinten noemen, dank voor je expertise en hulp rondom normaalwaarden.

Dorien, als CF verpleegkundige in Maastricht ben je de onmisbare spin in het web. Dank voor je hulp en interesse. Dat geldt ook voor de andere leden van het CF team en de 
verpleegkundigen op de afdelingen. Door mijn onderzoek heb ik des te meer ervaren dat goede zorg teamzorg is!

Secretaresses van het secretariaat Kindergeneeskunde in Maastricht, bedankt voor alle ondersteuning! Peggy, jij speciaal bedankt voor het plannen van alle besprekingen (gelukkig was er vaak toch een gaatje te vinden in de overvolle agenda's van 'de heren') en het meedenken en regelen van praktische zaken rondom mijn promotie. Tamara, wat zou de kindergeneeskunde zonder jou moeten... ook mij heb je vaak geholpen als ik weer een (financiële) vraag had, bedankt!

Polidames, dank voor jullie interesse en hulp tijdens het onderzoek en daarna.

Myrthe K, Sanne, Myrthe B, Sjoerd en Elles; als WESP studenten waren jullie betrokken bij veel praktische zaken rondom het onderzoek, dank voor jullie inzet en gedrevenheid.

Naast Bjorn Winkens zijn ook Gerard van Breukelen en Ariel Alonso betrokken geweest bij de statistiek van mijn promotietraject waarvoor veel dank.

Ger Rijkers en Ben de Jong, dank voor jullie harde werken in het lab in Nieuwegein en jullie verfrissende ideeën over analyse van biomarkers in EBC. Het was een hele prettige samenwerking.

Agnieszka, Jan, Frederik-Jan en Edwin Moonen, bedankt voor jullie expertise met betrekking tot het bepalen van de vluchtige stoffen in de uitgeademde lucht en jullie inbreng als co-auteurs. Agnieszka bedankt voor je analyses, je uitleg en de prettige samenwerking.

Marijke, Florence, Joek, Arno, Tine, Maarten en Mathieu, bedankt voor jullie ondersteuning vanuit het CTCM.

Maastricht Instruments, in het bijzonder Peter Gerits, bedankt voor de hulp en technische ondersteuning van de ademcondensors. Stephan Vervuren, bedankt voor de technische ondersteuning van zo ongeveer onze hele 'researchkamer', en ook de thuismonitoren. Wat was het soms een uitdaging om alles 'in de lucht' te houden. Met betrekking tot de thuismonitoren wil ik ook Skip Veugen, Maurice Ouwerling, Michael Taylor en Moritz Gmelin danken. 
Twan, Walther, Titia en Gijs, als opleiders in het MUMC en het Maxima MC waren jullie betrokken bij mijn opleiding tot kinderarts in combinatie met mijn promotietraject. René van Gent, je was maar kort mijn opleider in Veldhoven, maar met hoeveel enthousiasme! Je was voor mij een groot voorbeeld als mens, kinder(long)arts en opleider. Zelfs in de laatste weken voor je overlijden gaf je me nog goede adviezen.

Carien Smeets en Pim van Dijken, ooit hebben jullie in het Elisabeth ziekenhuis het onderzoeks vlammetje bij mij aangewakkerd. Jeannette Dankert en Jamiu Busari, in Heerlen heb ik onder jullie begeleiding verder kunnen groeien en ben ik uiteindelijk aangenomen voor de opleiding in Maastricht.

Arjenne Louter, wat kwam ik na de proefschriftschrijfdriedaagse thuis met veel tips en een berg inspiratie! Marcelle Uiterwijk, onze peer sessions hebben mij vaak verder geholpen tijdens het schrijfproces.

Lieve Dillys, we leerden elkaar kennen in de trein voor ik aan mijn promotietraject begon. Tijdens jouw zwangerschapsverlof nam ik kort ook het stokje van jouw onderzoek over en wat was ik blij toen je weer terug was! Samen hebben we ons door pittige tijden heen geworsteld. Wat heb ik veel van je geleerd en wat ben je een fijn en wijs mens! Ik ben vereerd dat jij mijn 'reserve-paranimf' wil zijn!

Ana, Bob, Britt, Elke, Ester, Gabriëlle, Inge, Jesse, Kylie, Maartje, Marlou, Sasha en Yvon, mijn onderzoekscollega's in Maastricht. Vanaf het begin heb ik me thuis gevoeld binnen jullie club, altijd oprechte interesse, een arm om je heen of een kop thee of koffie op het moment dat het nodig was. Een heel aantal van jullie zijn me voor gegaan, ik hoop dat de 'jongere garde' de rest van mijn boekenkast gaat vullen! Charlotte, Sanne, Michiel en Rick bedankt voor het luisterend oor, de interesse en de fijne samenwerking binnen het kinderlongteam.

Collega (oud)-assistenten uit Tilburg, Heerlen, Veldhoven en Maastricht. In het bijzonder Nicole, vanaf Tilburg zijn we goed bevriend, binnenkort maar weer eens een (kook)date plannen! Patricia, Rélana en Moniek ofwel de VVVV, bedankt voor de steun en support in Veldhoven en daarna. Eva, dank voor je knuffels op de poli en Irene fijn dat we aan het einde van onze opleiding elkaar beter hebben leren kennen! Ook voor alle andere AIOS, als ik het liedje van 'Friends' hoor krijg ik een lach op mijn gezicht! Dank voor jullie interesse en steun. 
Lieve buren; Léon \& Marieke, Joost \& Moniek we kwamen min of meer toevallig binnen 1,5 jaar allemaal 'op de laan' wonen, wie kon vermoeden dat je als buren zo snel vrienden wordt en er voor elkaar kan zijn! Ik geniet van jullie gezelschap, interesse en de spontane dates. Marieke en Richard, door onze kleine mannen die naar elkaar zwaaiden vanuit hun slaapkamers met elkaar in contact gekomen, ik hoop dat onze vriendschap verder zal groeien.

Beste heren en dames van vriendengroep 'de Ajonen', sinds ik Sander ken kom ik met plezier in Blitterswijck. Bedankt voor de gezelligheid!

Dennis en Suzanne, Daan en Manon, met of zonder kinderen, het is altijd fijn om af te spreken. Een hoogtepunt was voor mij afgelopen winter in de Efteling! Ik hoop dat we onze vriendschap verder kunnen uitbouwen. En Suzanne ik hoop van harte dat jij volgend jaar op deze plek staat.

Lieve geneeskundemeiden; Anne, Henrieke, Jetske, Lenka, Mirte, Rianne en Saskia. Vanaf het eerste jaar in Maastricht kennen we elkaar, grotendeels via de eerste onderwijsgroep! Al lukt afspreken minder vaak dan we zouden willen en zijn we vaak verre van 'compleet' het is erg fijn om jullie om me heen te hebben en af en toe eens lekker te kunnen ventileren over het leven als arts maar juist ook alles daar omheen!

Lieve Ilse, ook een van de geneeskundemeiden. Vanaf dag één van onze studie gingen we samen op pad. Jij ging me voor op deze promotiereis en 5 jaar geleden mocht ik jouw paranimf zijn. Vandaag is het andersom. Ik bewonder hoe je je werk en je gezin combineert, nu zelfs dagelijks op en neer naar Leiden voor je fellowship. Ik hoop dat er weer wat rustiger tijden komen en we weer tijd hebben voor sauna- en of shopdates en bijkletsen met een kop thee!

Lieve Anne, Ellen, Ineke, Merijn en Willemien (ofwel de meiden van PUH). We zijn vriendinnen vanaf de middelbare school en nog steeds erg hecht, wat ben ik dankbaar voor onze goede vriendschap! Ik zie ons al als 65 plussers druk kletsend met de trein naar een leuke bestemming gaan! Ik hou van jullie! Orlando, Peter, Rob en Bart bedankt voor jullie interesse en gezelligheid!

Lieve Roos, Jeroen en Daphne, Martijn en Kim, een fijnere schoonfamilie had ik me niet kunnen wensen! Roos, vanaf dag één heb ik me bij jullie thuis gevoeld. Jij staat altijd voor ons (en iedereen) klaar en vergeet daarbij jezelf wel eens. Je hebt je de afgelopen jaren door heel wat moeilijke momenten heen geworsteld, ik bewonder je veerkracht en 
doorzettingsvermogen. André zou trots op je zijn! Hopelijk gaat ook voor jou de zon steeds weer wat meer schijnen. Jeroen en Daphne, Martijn en Kim, het is altijd fijn om samen te zijn. We zijn er echt voor elkaar, dat hebben we de afgelopen jaren wel gemerkt. Juist tijdens en door deze heftige perioden merk je wat belangrijk is! Wat is het heerlijk om met alle kinders op pad te gaan en samen te genieten.

Lieve John, mijn schoonvader, wat zou je trots zijn geweest als je wist dat een van jouw schilderijen nu de basis voor de kaft van mijn proefschrift is en dat Wout er ook nog in figureert. Ik had je zo graag nog beter willen leren kennen, soms is iets nog niet af wanneer het eindigt...

Lieve pap en mam, het is niet in een paar zinnen te vatten wat jullie voor mij betekenen. Jullie zijn een hecht team en hebben Laura en mij zo'n fijne en warme basis gegeven in Horst. Jullie hebben altijd in me geloofd en achter mijn keuzes gestaan, dankzij jullie ben ik (op)gegroeid tot wie ik nu ben. Ook hebben jullie me geleerd om van kleine dingen te genieten, pluk de dag! Ik bewonder jullie en prijs me zeer gelukkig met zo'n fijn gezin om me heen, ik hou van jullie!

Lieve Laura, mijn allerliefste zus. Wat ben ik blij met jou als zus, vriendin en nu ook paranimf. We hebben meestal aan een woord genoeg, jij begrijpt me altijd meteen! Ik mocht jouw getuige zijn bij jullie huwelijk, nu mag jij aan mijn zijde staan! Ik ben trots op je en hou van je! Eigenlijk vind ik Haarlem wat te ver weg en zou ik je vaker willen zien en knuffelen maar ik zie hoe gelukkig je daar bent met Menno en jullie kleine meid op komst! Menno jij vult Laura aan en bent er als het nodig is voor haar en voor ons. Ik ben heel blij met jou als schoonbroer.

Sander, mijn allerliefste lieverd, de wereld is mooier met jou. Ik hou zoveel van je, dat is niet te beschrijven... Inmiddels ben ik een groter deel van mijn leven met jou dan zonder jou, dat is echt bijzonder, we zijn zo mooi met elkaar mee gegroeid en vullen elkaar heel goed aan. We hebben al veel meegemaakt samen... Je staat altijd voor me klaar en steunt me bij alles wat doe. Wat genieten we samen van Wout, het is zo'n heerlijk ventje! Nu wordt het tijd voor een volgend hoofdstuk!

Lieve Wout, ons grote wonder, jij bent mijn alles. Mama's boekje is nu af en jij steelt de show op de voorkant! Ik kijk uit naar alle avonturen die we nog samen gaan beleven! 

Curriculum Vitae 



\section{Curriculum Vitae}

Marieke Wilhelmina Petronella van Horck was born on $14^{\text {th }}$ June 1983 in Horst, the Netherlands. After obtaining her high school diploma at the 'Dendron College' in Horst, she started her medical training at the Faculty of Health, Medicine and Life Sciences of the Maastricht University Medical Centre $\left(\mathrm{MUMC}^{+}\right.$) in 2001. As part of the curriculum she attended an elective internship primary health care in Damongo, Ghana. After her final internship at the Paediatric Intensive Care Unit (dr. G. Vos) and scientific internship at the department of obstetrics and gynaecology (prof. dr. J. Nijhuis and dr. M. Hendrix), she obtained her medical degree in 2007. From 2007-2009

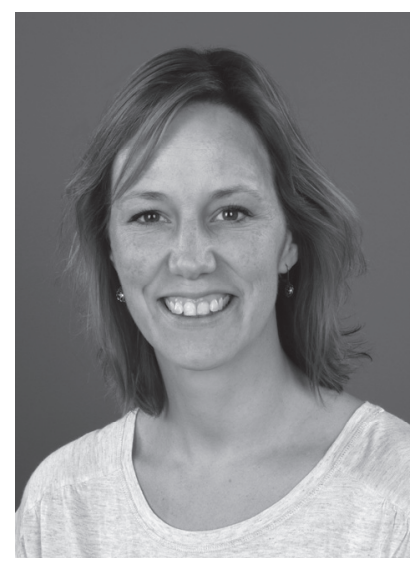
she worked as a medical doctor at the paediatric department of the St. Elisabeth Hospital in Tilburg (dr. P.J. van Dijken and dr. C. Obihara). During that period she became interested in paediatric respiratory medicine and designed a multi-centre randomised clinical trial to study moderate asthma exacerbations in children (drs. C. Smeets). In 2010 she worked at the paediatric department of the Atrium Medical Centre (currently Zuyderland Medical Centre) in Heerlen (dr. J. Dankert and dr. J. Busari) and continued her research project. In 2011 she started her training as a paediatric resident at the MUMC $^{+}$(prof. dr. L. Zimmermann and dr. A. Mulder) and Máxima Medical Centre in Veldhoven (dr. R. van Gent, dr. W. Tjon A Ten and dr. L. Niers). In the same year she started her PhD project in children with cystic fibrosis at the department of paediatric respiratory medicine of the MUMC+ and the School for Public Health and Primary Care (CAPHRI) under supervision of prof. dr. E. Dompeling, prof. dr. G. Wesseling, dr. B. Winkens, and dr. Q. Jöbsis. Her research has resulted in several WI1 publications and international presentations. In August 2017 she started her final clinical training at the department of paediatric respiratory medicine of the MUMC', and she will graduate as a paediatrician in 2018. She has been together with Sander for over 17 years, they live together in Roermond, and are the proud parents of Wout. 

List of publications 



\section{List of publications}

van Horck M, Winkens B, Wesseling G, de Winter-de Groot K, de Vreede I, Jöbsis Q, Dompeling E. Factors associated with changes in health-related quality of life in children with cystic fibrosis during 1-year follow-up. Eur J Pediatr (2017) 176:1047-1054

van Horck M, Alonso A, Wesseling G, de Winter-de Groot K, van Aalderen W, Hendriks H, Winkens B, Rijkers $G$, Jöbsis $Q$, Dompeling E. Biomarkers in exhaled breath condensate are not predictive for pulmonary exacerbations in children with cystic fibrosis: results of a 1-year observational study. PLoS One 2016;11(4):e0152156

van Vliet D, van Horck M, van de Kant K, Vaassen S, Gulikers S, Winkens B, Rosias P, Heynens J, Muris J, Essers B, Jöbsis Q, Dompeling E. Electronic monitoring of symptoms and lung function to assess asthma control in children. Ann Allergy Asthma Immunol. 2014;113:257-262

Hendrix M, Van Horck M, Moreta D, Nieman F, Nieuwenhuijze M, Severens J, Nijhuis J. Why women do not accept randomisation for place of birth: feasibility of a RCT in The Netherlands. BJOG. 2009;116:537-42

van Horck M, Winkens B, Wesseling G, van Vliet D, van de Kant $K$, Vaassen S, de Winterde Groot K, de Vreede I, Jöbsis Q, Dompeling E. Early detection of pulmonary exacerbations in children with cystic fibrosis by electronic home monitoring of symptoms and lung function. Accepted for publication, Scientific Reports 2017

van Horck M, van de Kant K, Winkens B, Wesseling G, Gulmans V, Hendriks H, van der Grinten C, Jöbsis Q, Dompeling E. Risk factors for future exacerbations in children with cystic fibrosis. Submitted

van Horck M, Smolinska A, Wesseling G, de Winter-de Groot K, de Vreede I, Winkens B, Jöbsis $Q$, Dallinga J, Dompeling E, van Schooten F. Exhaled volatile organic compounds early detect pulmonary exacerbations in children with cystic fibrosis: results of a 1-year observational study. Submitted 
